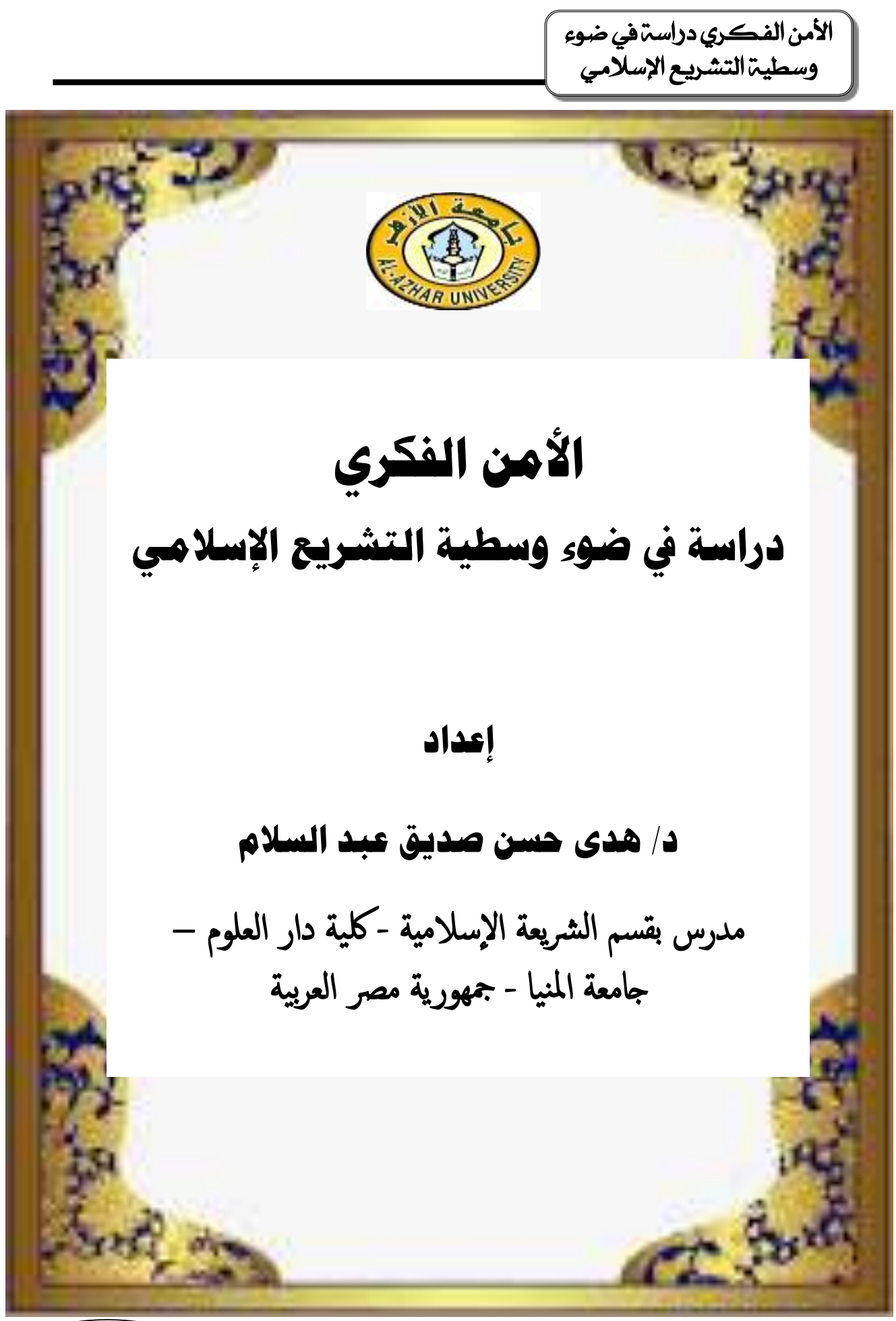

\title{
1. 94
}

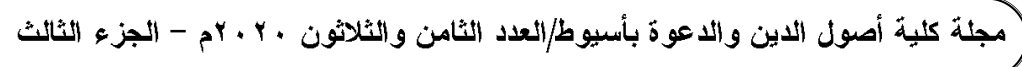


الأهن الفكري، دراسة في ضوء وسطية التشريع الإسلاهي

هلى حسن صديق عبد السلام قسم : الثريعة الإسلامية- كلية دار العلوم- جامعة المنيا- جمهورية مصر العربية

\section{البريد الاككتوني: dr.hudahasan@mu.edu.eg}

\section{ال|lin}

بدأت الباحثّة بحثها بالحديث عن أهمية الأمن الفكري، وكيف أنه

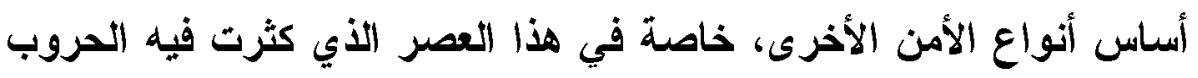

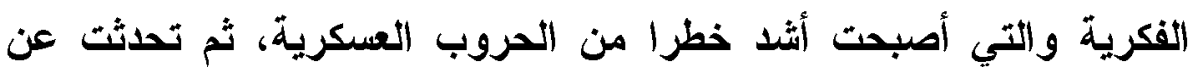
أسباب الاحراف الفكري، وأوضحت ضرورة مواجهتها والتصدي لها بها بكل

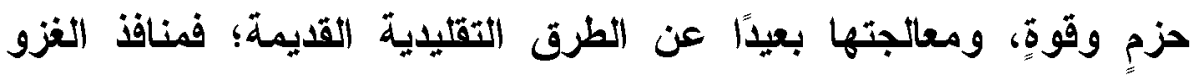

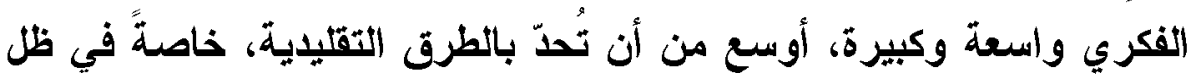

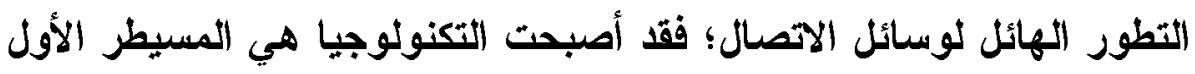
على عقول الثباب والمؤثر الفاعل فيه، ثم تحدثت الباحثة عن وسطيّة الثيّة

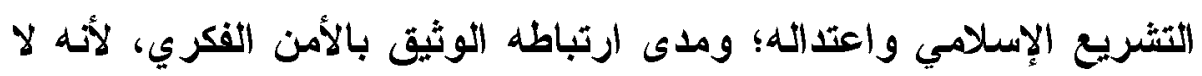

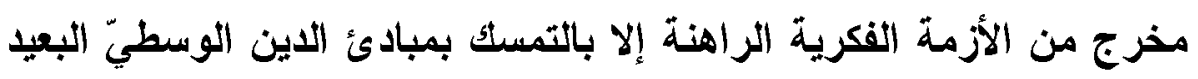
عن التثدّد و التعصبّ و المغالاة .

الكلمات المفتاحية: أمن، فكر، وسطية، غزو فكري، دين، تثريع • 


\section{Intellectual Security, a study in light of the moderation of Islamic legislation}

Hoda Hassan Siddiq Abdul Salam

Department of: Islamic Sharia (law) - Faculty of Dar Al Uloom (Home of Science) - Minia University - Arab Republic of Egypt

Email: dr.hudahasan@mu.edu.eg

\section{Abstract}

The researcher began her research by talking about the importance of intellectual security and how it is the basis of other types of security especially in this era in which intellectual wars have abounded and which have become more dangerous than military wars. Then I talked about the reasons for intellectual deviation showing the necessity of facing and resisting it strictly and strongly and treating them far away from old traditional methods as the means of intellectual invasion are too wide to be limited by traditional methods, especially in light of the tremendous development of means of communication.

Technology has become the first dominant and influential factor on the minds of the youth. Then the researcher spoke about the moderation of Islamic legislation and how it is closely related to intellectual security because there is no way out of the current intellectual crisis except by adhering to the principles of the moderate religion that is far away from extremism, fanaticism and exaggeration.

Keywords: security, thought, moderation, intellectual invasion, religion, legislation. 


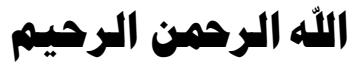

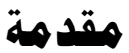

الحمد لله رب العالمين، والصلاة والسلام على سيد الخـــن أجمعـين،

سيانا محمد وعلى آله وصحبه ومن تبعهم بإحسان إلى يوم الاين ل...

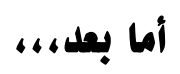

فإن نعمة الأمن من أهم النعم التي منّ الله - تعالى - بها علينا، وليس

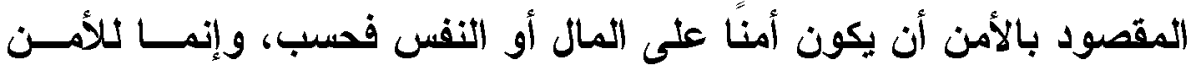

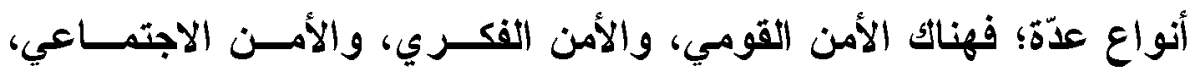
والأمن الاقتصادي، والأمن السياسي، والأمن الغذائي... إلى آخر ذلكك مسن

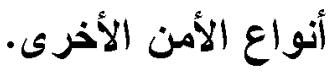

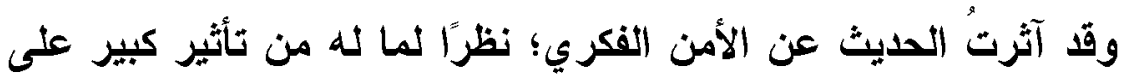

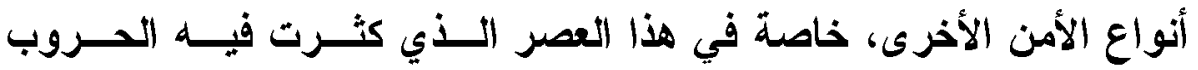

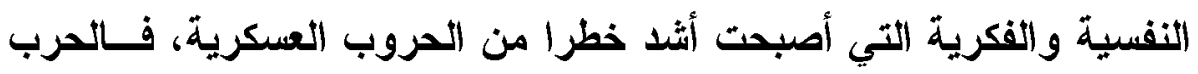

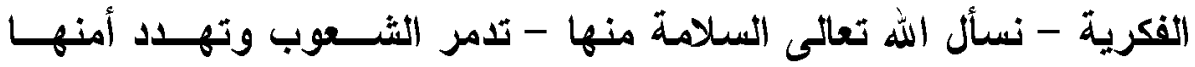
و وسلامتها.

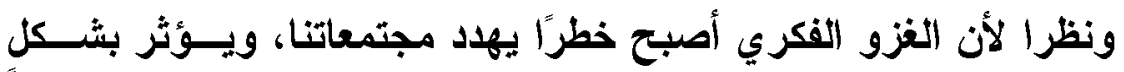

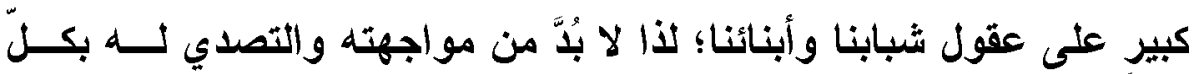

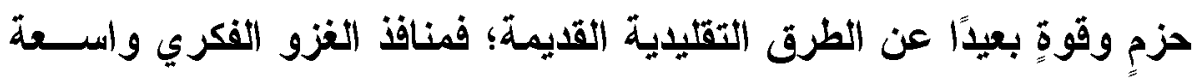

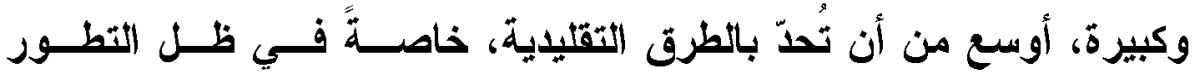

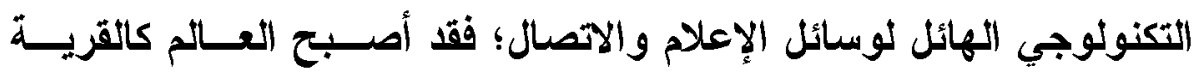

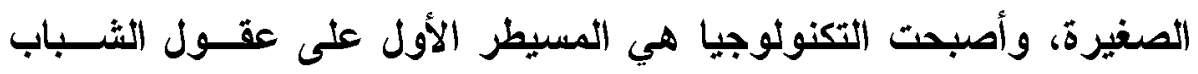

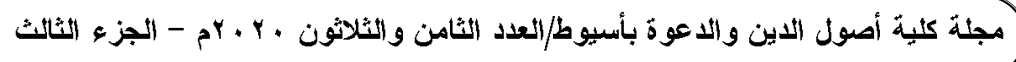


والمؤتر الفاعل عليه.

وقد قمتُ بربط موضوع الأمن الفكري” بوســيّة الإســلام واعتدالــهـ

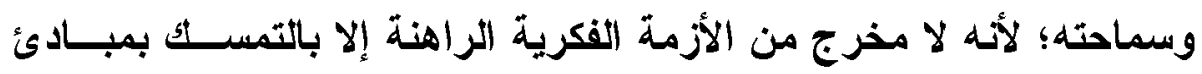

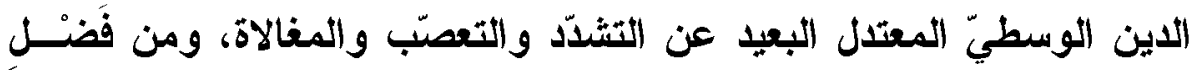
الله على أمتنا الإسلامية أن ميزها بميزة لم تكن لأمـة من الأمم السابقة، ألا

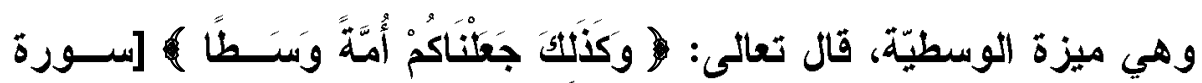
البقرة من الآية: بـ؛]]، ومن المتعارف عليه أن لفظ (الوسطيّة) لفظ كبير ومتعدد المعاني، ويثمل أكثر من مدلول، والمتأمل في تفسير هذا اللفظ يجد

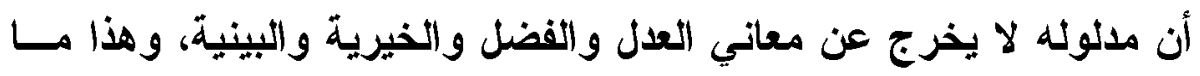
سيتضح في ثنايا البحث.

هذه هي حقيقة الإسـلام التي أخبر بها القرآن الكريم والســنة النبويــة المطهرة، دين حنيف وسطي معتدل، ينبذ التثدد والتطرف والمغالاة، قـال

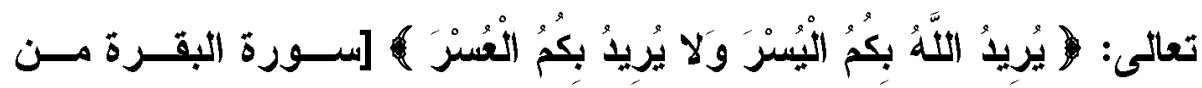

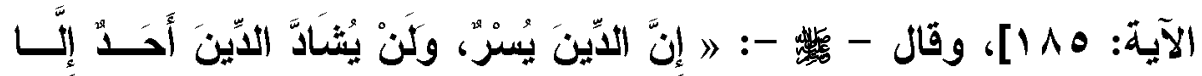
غَلَبَهُ .... (1) (1) لكن ابتُلينا ببعض المرتزقة الجهلاء الذين يحاولون تشــويه صــورة الاين الوسطيّ المعتدل؛ وذلك بنفي صفة الوسطيّة والاعتدال عنه، وإضفاء

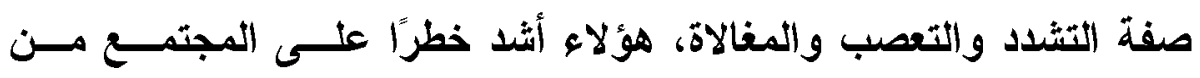

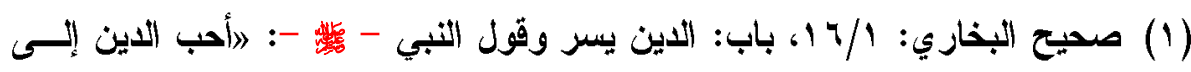

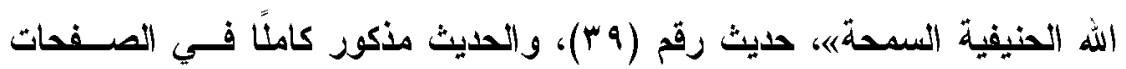
القادمة. 
غيرهم، فيجب التصدي لهم وبيان ضعفهم وكذبهم وافتــرائهم، والتحـــير منهم ومن أفكارهم الهدّامة التي تسعى لهـم مبادئ الاين الوسطيّ الحنيف، واستبدالها بأخرى ما أنزل الله بها من سلطان.

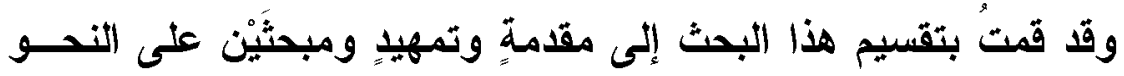

المقدمة: وفيها أهمية الموضوع ومضمونه.

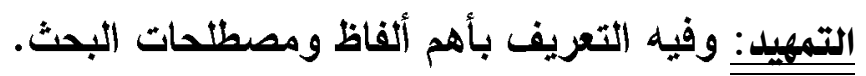
والمجحث الأول: في الأمن الفكري؛

المطلب الأول: الأمن الفكري في الإسـلام. المطلب الثاني: أهمبة الأمن الفكري. المطلب الثالث: أسباب الاتحر اف الفكري. المطلب الرابع: وسائل حماية الأمن الفكري. المبحث الثاني: جعلته للحسيث عن وسطية التشريع الإسلامي في تحقيق الأمن الفكري. ثم الخاتمة: وفيها أهم النتائج والتوصيات.

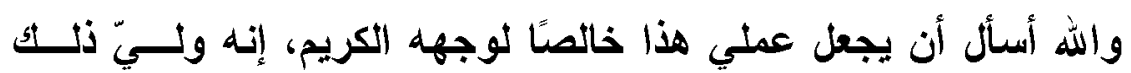
والقادر عليه. - مله. 


\section{تمهيد: تعريف هصطالمات البمث:

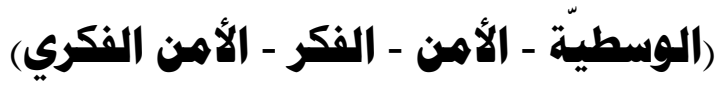 \\ أولًا: تعريف الوسطيّة:}

الوسطيّة في اللفة: كلمـة (وسط) في اللغذة تثمل عدّة معسـان مُتثاربــة الالالة؛؛ وذلك على النحو التالتي:

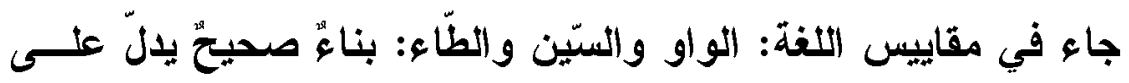
العدل والنّصف. وقال ابن منظور: ووسط الثيء وأوسطه: أعدله. وتأتي لفظة (وسط) بالثتح والسكون: فتأتي بالفتح بمعنى التوسيُّ فئي الثشيء، قال الجوهري في الصحاح (وسنَط) : الثشيء بين الجيد والـــرديء؛ وتأتي - بالقتح أيضًا - صفة بمعنى خيار وأفضل وأجود، فأوسط الثــيء

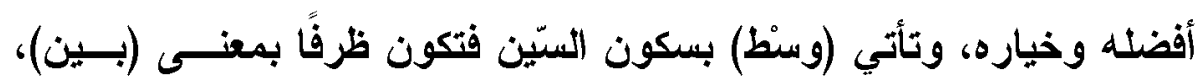
تقول: جلست وسنط القوم أي: بينهم. وكيفما تصرفت هذه اللفظة نجدها لا تخرج في معناها اللغـوي عـن معاني العدل و الفضل والخيرية والبينية وما شابه ذلتك(1).

(1) انظر في معاني (الوسط): معجم مقاييس اللغة لابن فارس: 1/1 • 1 مادة: (وسط)،

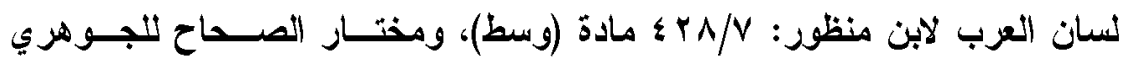

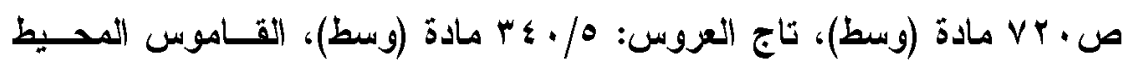

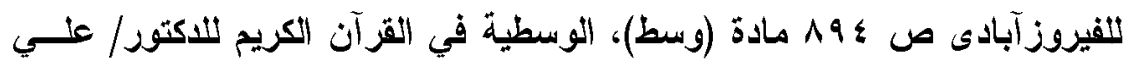

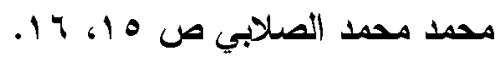


الوسطيّة في اصطلاح الفقهاء: ورد لفظ (الوسط) في الثرآن الكريم فـي

أكثر من موضع على التحو التالي:

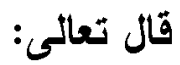

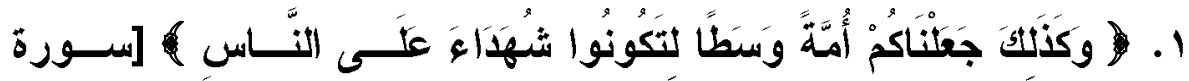

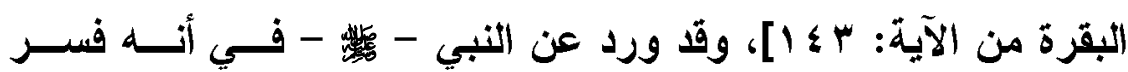
الوسط في هذه الآية بالعدل (1)، وقال الإمام الزرازي - هيَّه، - في تفسير

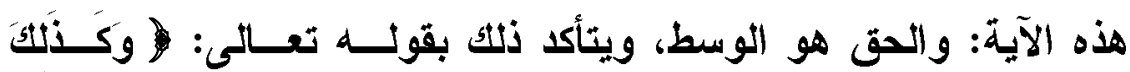

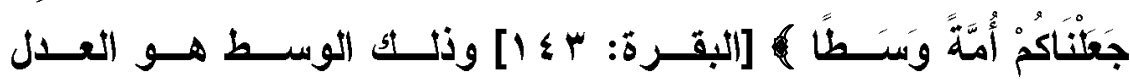

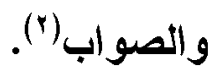

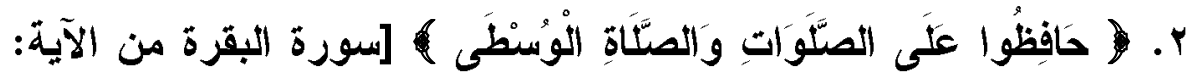

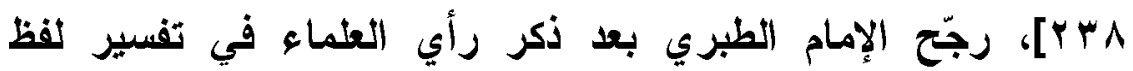
(الوسطى) أن المقصود بالصلاة الوسطى هي صدلاة العصر؛ لتوسطها الصلوات المكتوبات الخمس، وذلك أن قباتها صلاتين (الصبح والظهر)، وبعدها صلاتين (المغرب والعشاء)(ّ)، فالوسط هنا بمعنى البينيّة أي الوسط بين الثبيئين.

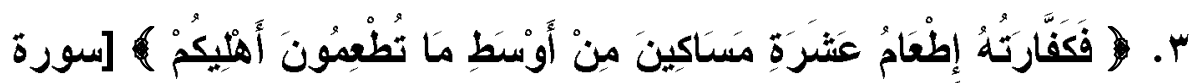
المائدة من الآية: 9 ــ].

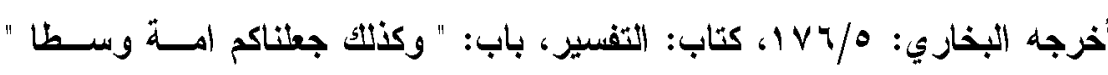

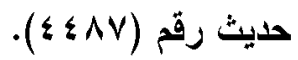

$$
\begin{aligned}
& \text { تفسير الرازي: } \\
& \text { تفسير الطبري: به/r }
\end{aligned}
$$

\subsection{9}

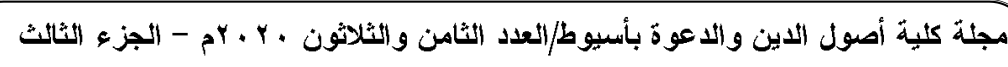


تعددت أقوال المفسرين في تفسير لفظ (أوسط) الوارد في هذه الآيـــة

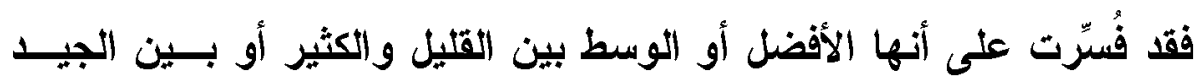

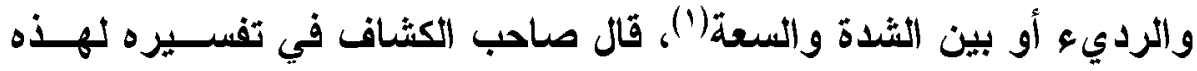

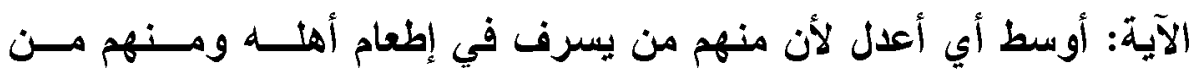
يقتر (").

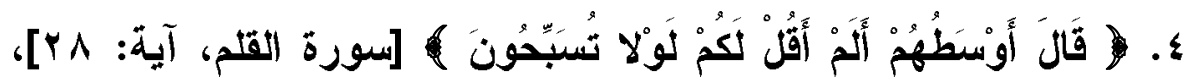

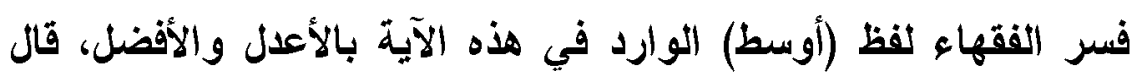

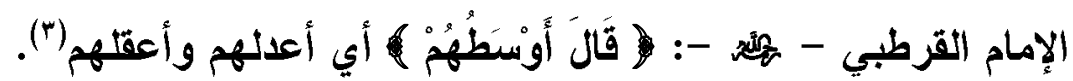

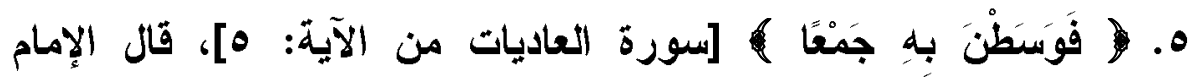

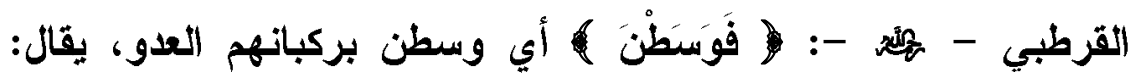
وسطت القوم: أي صرت وسطهم(\&)، يقصد وسطهم في المكان .

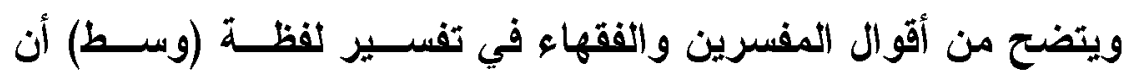
مدلوثها لا يخرج عن معاني العدل والفضل والخيرية والبينية(ه).

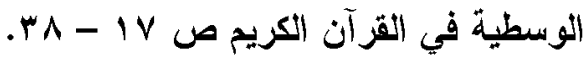

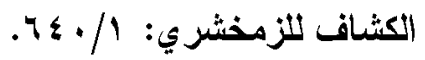

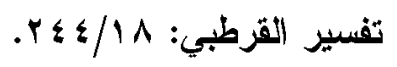

$$
\begin{aligned}
& \text { تفسير القرطبي: • ب/ • 14. } 14
\end{aligned}
$$

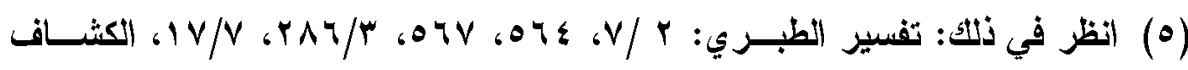

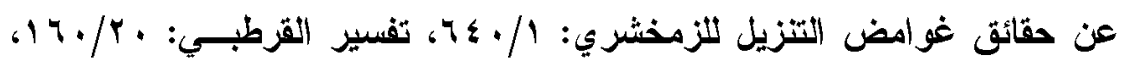

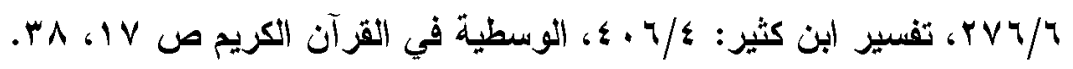

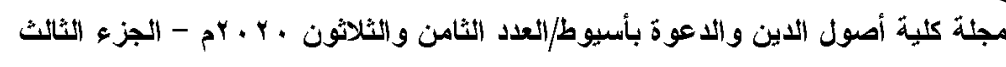




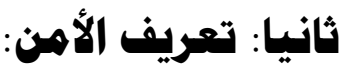

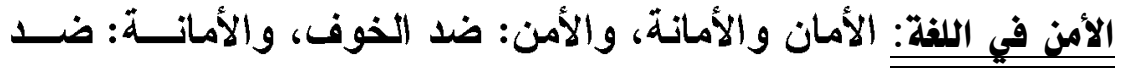

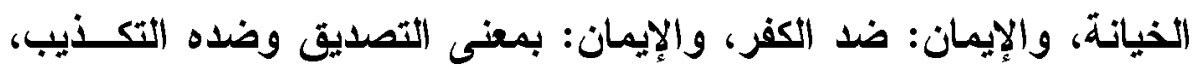

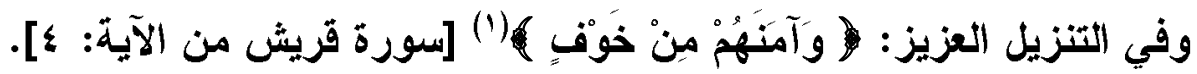

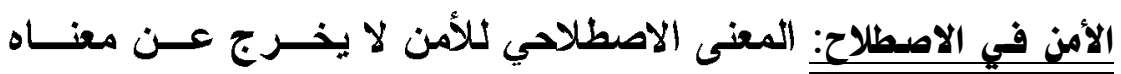

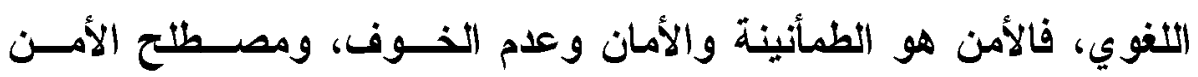

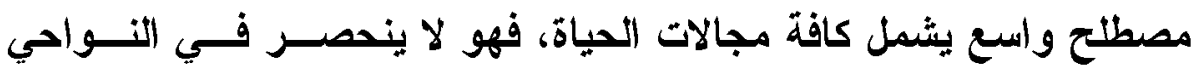

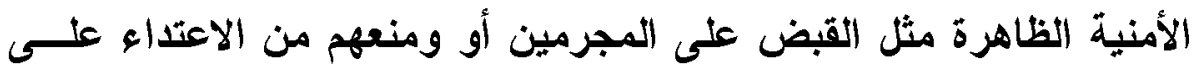

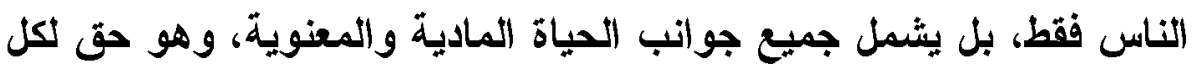

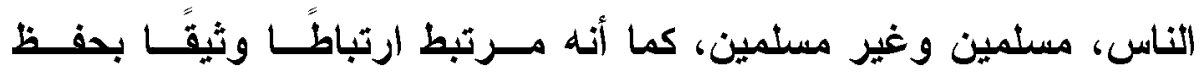
الضرورات الخمس؛ وهي الاين والنفس والعقل والعرض والمال.

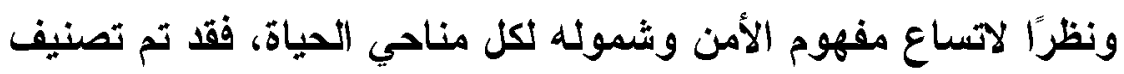

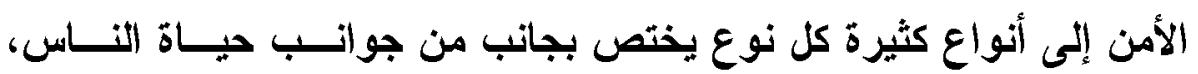

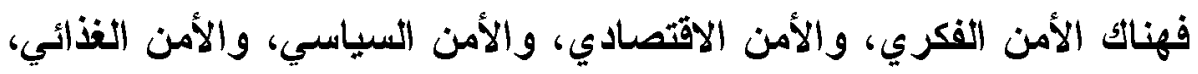
والأمن الجنائي، والأمن الاجتماعي ل... وغير والأنها.

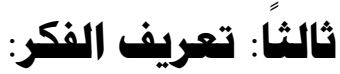

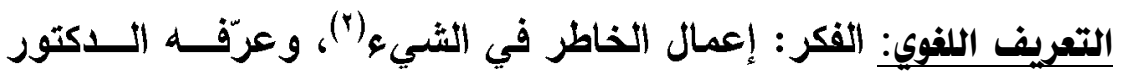
عبد الله الجربوع(r) بقوله: الفكر اسم جنس يطلق على الأفكار الحاصلة من

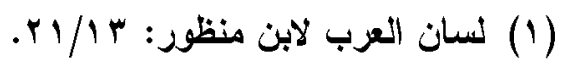
r) (T) رئيس قسم العقيدة بالجامعة الإسلامية بالمدينة المنورة.

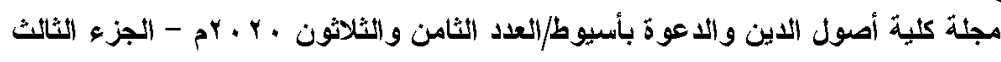


وظيفة التفكير والتعقل والنظر التي أودعها الله تعالى في قلوب الناس(').

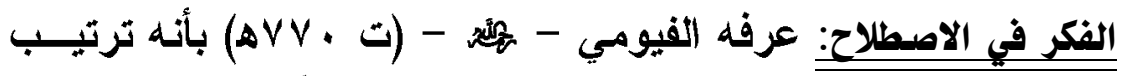

أمور في الذهن يتوصل بها إلى مطلوب يكون عثمًا أو ظنَّاُ (r).

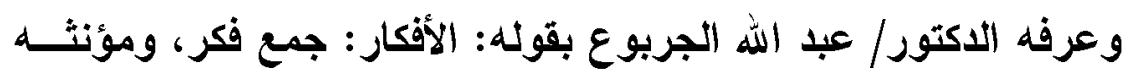
فكرة، وير اد به معنيان: الأول: الفعل الذي تقوم بـ النفس عند حركتها في المعقولات، وهــــه هي عملية التفكر والنظر. والثاني: يطلق على المعقولات نفسها، أي المعقولات والمعسـاني التـي تتتج عن تفكر البشر وتأخذ شكل عقيدة أو مبدأ يؤمن به، فتتكـون منـــهـ العقائد والتصورات البثرية المصدر، وتكون باعثة ومؤثرة على الســلـوك، وهذا هو المعنى المراد، ويلذخل في ذلك عقائد ومفاهيم الأديـان البثــرية

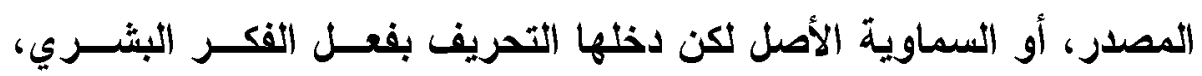

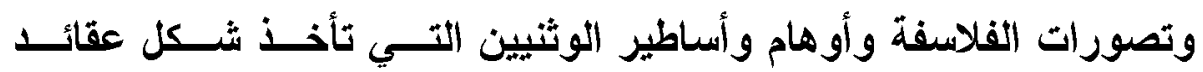
وقناعات وتصورات معتبرة، ولا ياخل فيه عقائد وشرائع الاين المحفــوظ لأتها ليست نتائج فكر بشري بل هي وحي إلهي (r).

(1) أثز الإيمان في تحصين الأمة الإسلامية ضد الأفكار الهـامــة للـدكتوز / عبـــ الله

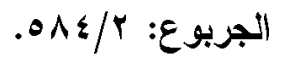

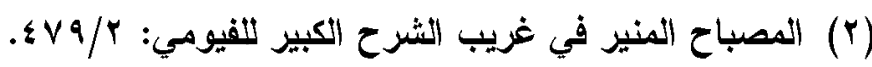

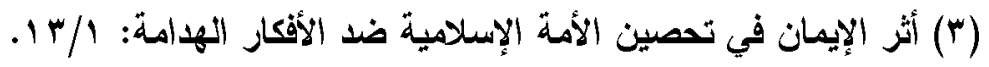




\section{رابعاً: تعريف الأهن الفكري:}

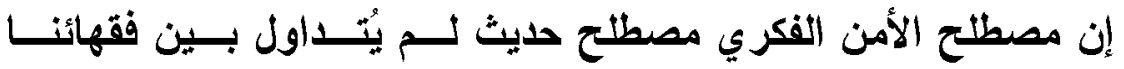

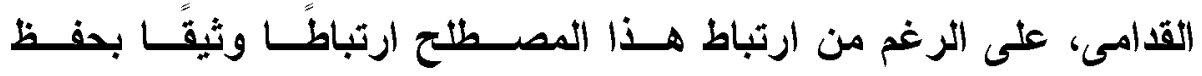
الضرورات الخمس الأي هو من أهم مقاصد هذه الثريعة الغزاع، فالمتأمل

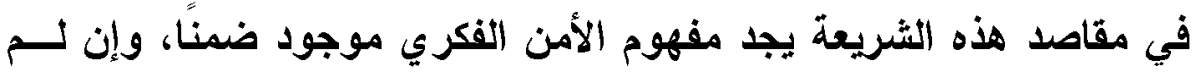

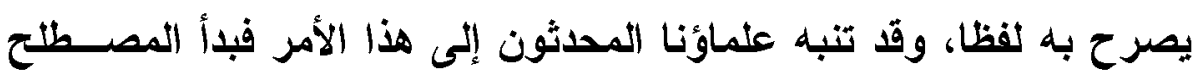
يظهر ويُشاع وينتشر بين العلماء وتتحدد ملامحه، وبدأ العلماء بالتأصــيل

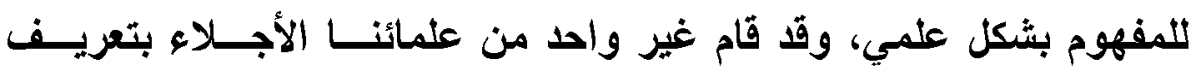

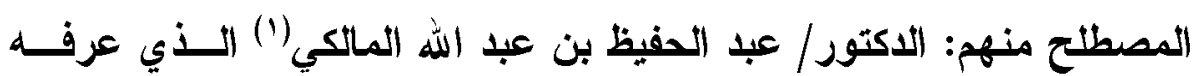
بقوله: الأمن الفكري هو سلامة فكر الإنسان من الاتحراف، أو الخروج عن الوسطيّة والاعتدال، في فهمه للأمور الاينية والسياسية والاجتماعية، مما يؤدي إلى حفظ النظام التعام والأمن والطمأنينــة والاســتقرار فــي الحيــاة السياسية والاقتصادية والاجتماعية وغيرها من مقومات الأمن الوطني ().

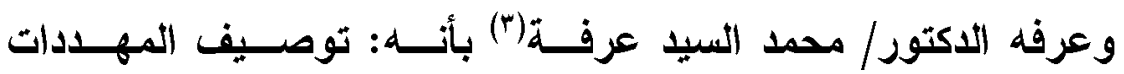

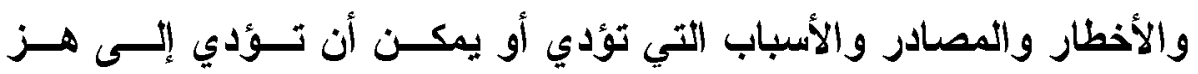
القناعات الفكرية، أو الثوابت التعقية، أو المقومات الأخلاقية والاجتماعيــة

(1) أستاذ بجامعة نايف العربية للعلوم الأمنية . (1)

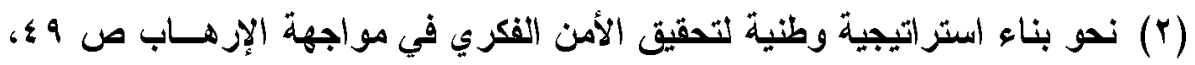

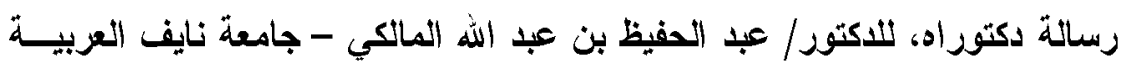

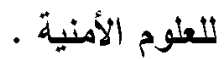
(r) أستاذ القانون الاولي بكلية الحقوق - جامعة المنصورة.

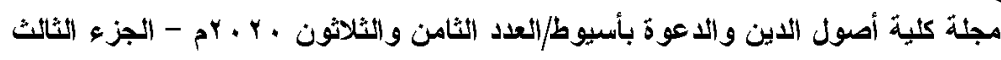


والاينية للأمن الوطني ('). وعرّته الاكتورة/ هانم محمد عوض(r) بأنه: تحقيق الاستقرار العقدي والأخلاقي والسلوكي والاجتماعي، وإيجاد الوسائل للوقاية مـن غزوهــــا،

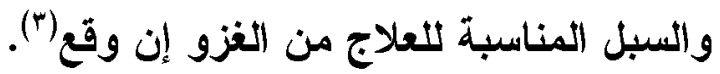

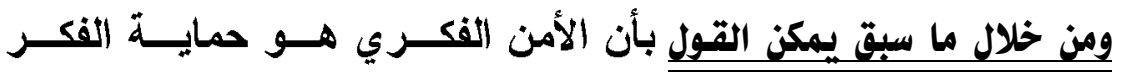
الإتساني من الاتحر اف، وإيجاد سبل الوقاية من هذا الاتحر اف عند وجوده.

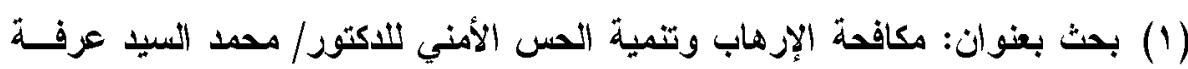

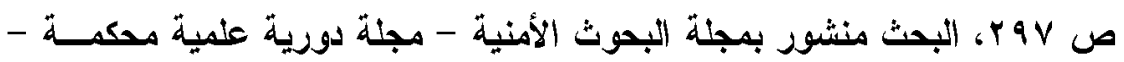

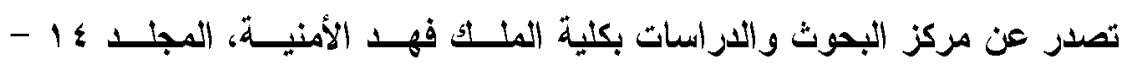

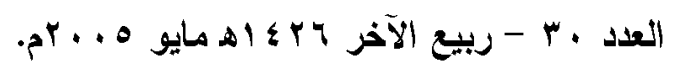

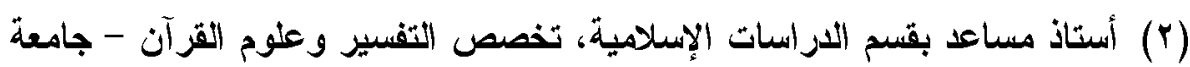
الملك خالا. بحث بعنوان: وسائل القزآن الكريم في تحقيق الأمن الفكري للاكتورة/ هانم محمد

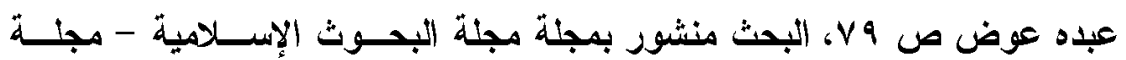

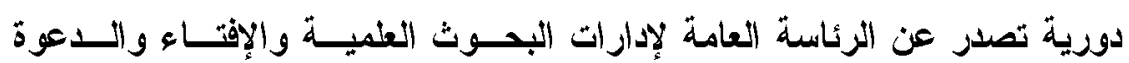

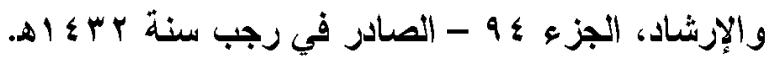

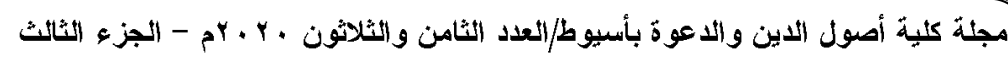




\section{المبحث الأول \\ في الأهن الفكري

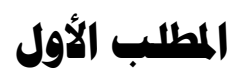

الأهن الفكري في الإسلام

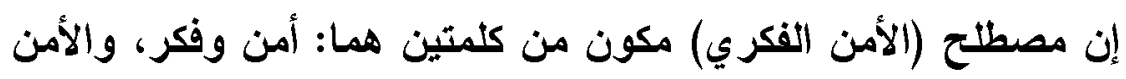

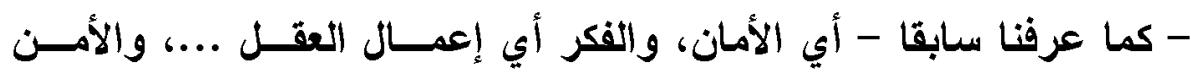

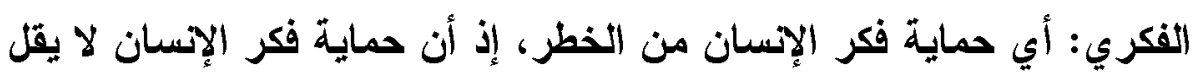

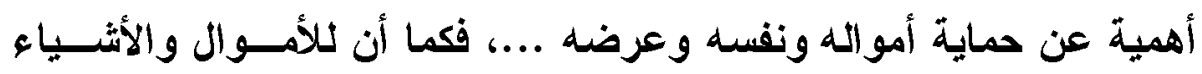

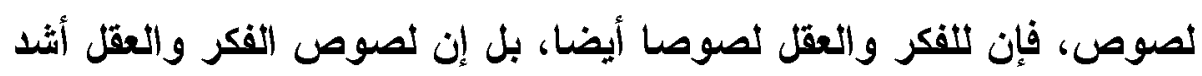

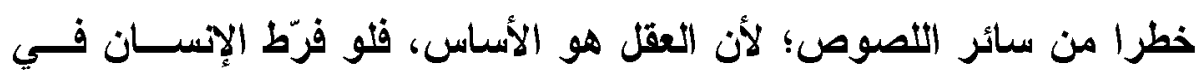

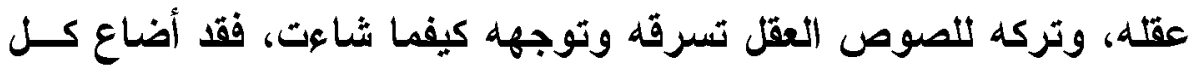

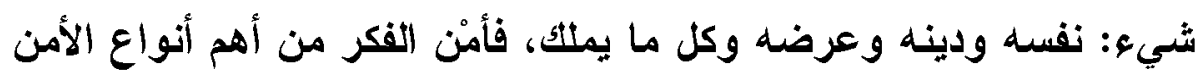
التي يجب المحافظة عليه، وحمايته من كل ما يثوهله أو يؤذيه.

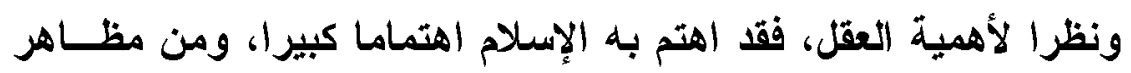

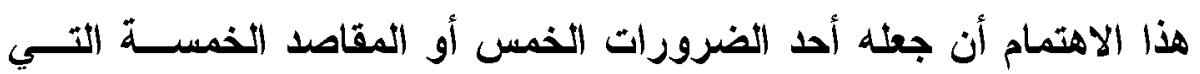

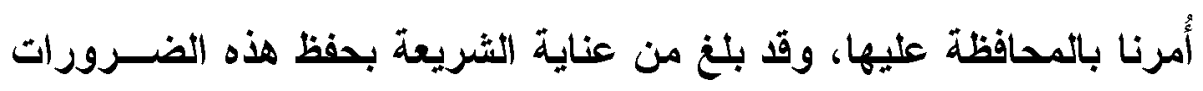

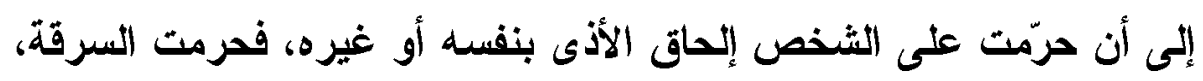

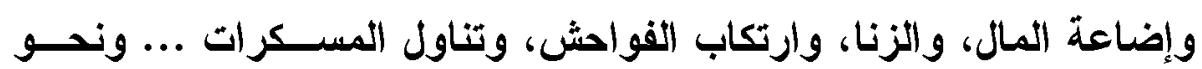

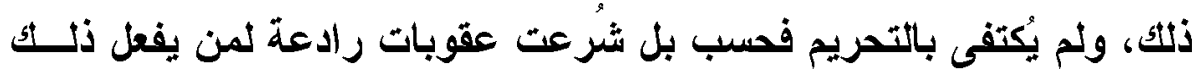

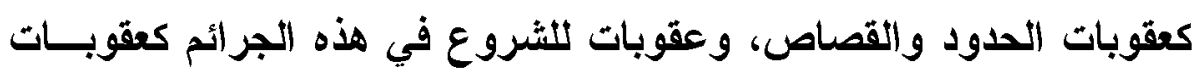

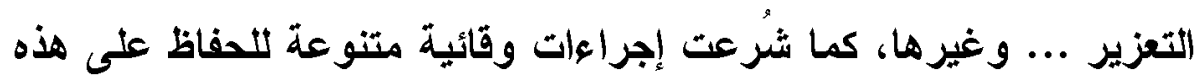




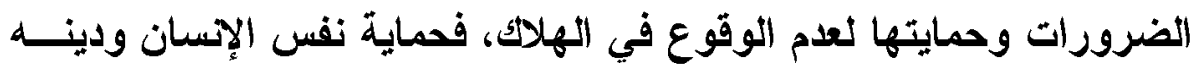
وعقله وعرضه وماله، من أبرز الاهتمامــات فـي الثــريعة الإســلامية،

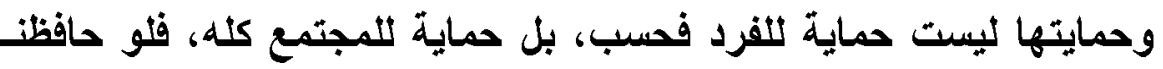
على هذه الضرورات فقا حافظنا على المجتمع بأكمله.

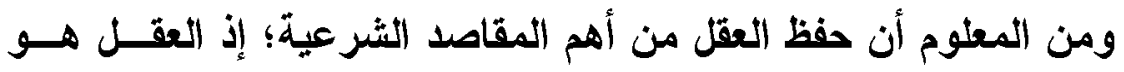
المتحكم الرئيس في حياة الإنسان، فبه بفكر، وبه بزن الأمسـور فيسـتطيع التقرقة بين ما هو نافع وما هو ضار، وبين ما هو خير وما هو شر، وبين ما هو جميل وما هو قبيح، وبه يدرك حقائق الأمور وخباياها، لذلك أمرنــا الله تعالى بالمحافظة عليه، فحرم الاعتداء عليه بما يضره حتى يكون فـي

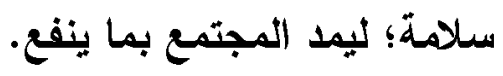
وتظهر قيمة العقل وأهميته حينما حرّم الله تعالى الخمر وكل مـــا هــو

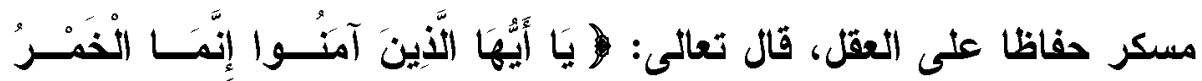

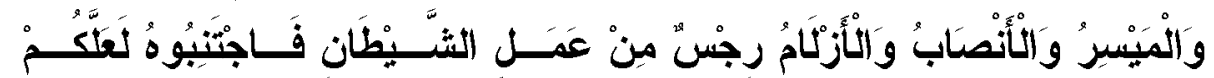

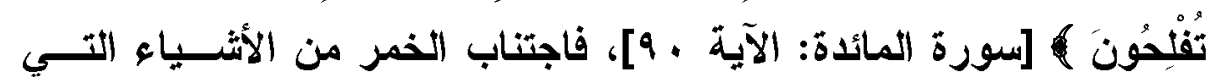
تضمن لإِنسان الفلاح.

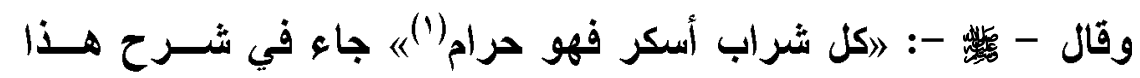
الحديث: أنه إذا أسكر الثراب فقد وجب اجتنابه لنجاسته، وحرم اســتعماله في كل حال، ولم يحل شربه(؟)؛ لأنه يضر بالعقل.

(1) أخرجه البخاري في صحيحه: 1N/1ه، باب: لا يجوز الوضوء بالنبيذ، ولا المسكر،

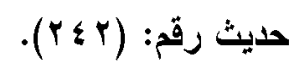

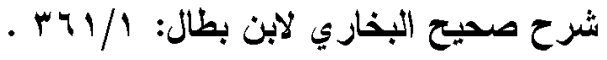


وقد أطلق سلفنا الصالح على الخمر اسم "أم الخبائث"؛ لأتها مفتاح كل شر، فقد روى البيهزي في سنته قول سيدنا عثمان بن عفــان، رضــي الله عنه: "اجتنبوا الخمر، فإنها أم الخبائث، فإنه كان رجل ممن خلا قبلكم يتعبد ويعتزل الناس، فعلقته امرأة غوية، فأرسلت إليه جاريتها فقالت: إنا ندعوك أنك لشهادة، فذخل معها وكلما دخل بابا أغلقته دونـه، حتى أفضى إلــى امـــرأة وضيئة عندها غلام وباطية خمر، فقالت: إني والله ما دعوتثك ثشهادة، ولكن دعوتلك لتثع علي، أو تقتل هذا الغلام، أو تشرب الخمر، فسقته كأسا، فقال: زيبوني، فلم يزم حتى وقع عثيها وقتل النفس، فاجتنبوا الخمــر، فإنهــا لا

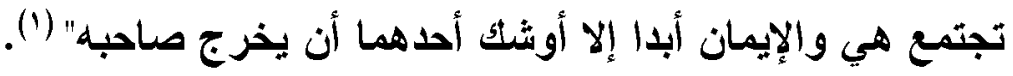
وفي هذا الأثر نلاحظ قول سيدنا عثمان بن عفان - مئه - أن الخمر لا تجتمع هي والإيمان أبلا، والإيمان هنا أي الأمن سواء أكان أمن اجتماعي، أم اقتصادي، أم فكري، أم سباسي، أم ديني ... أم غير ذلتك من أنواع الأمن

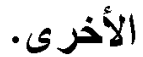

كما نلاحظ أنه مع غياب العقل ارتكبت الفواحث من قتل وزنا وغيرها، فالعقل إذن هو الميزان الأي بموجبه يزن الإنسان الأمور كلها، فيسـتطيع التمييز بين ما ينفعه وما يضره. وعلى الرغم من أن مصطلح الأمن الفكري لم يكن شائعا كمسمى لفظي بين فقهائنا القدامى، إلا إنها مصطلح قديم المدلول، فقد كان سلفنا الصــالح يعملون دوما على ســلامة عقــولهم، وصـــونها مــن أي أذى أو ضــرر،

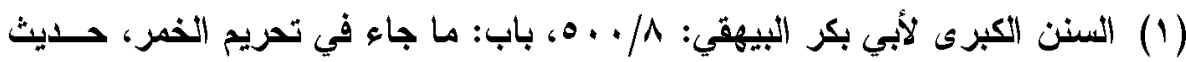
رقم (IVrra) 
وحمايتها مما يلوثها أو يشوه أقكارهم، والقرآن الكريم ملــيء بالقصــص

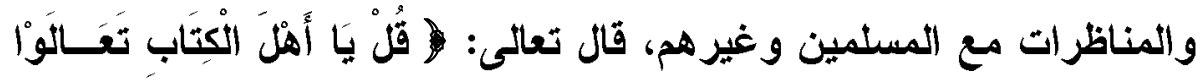

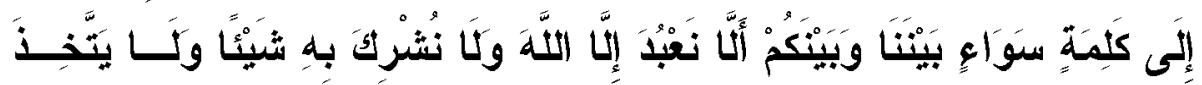

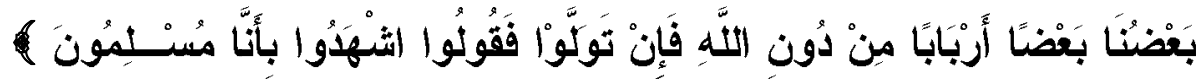
[سورة آل عمران آية: ؛ ؟]، جاء في تفسير هذه الآية: قل يا محمد لأهـلـل

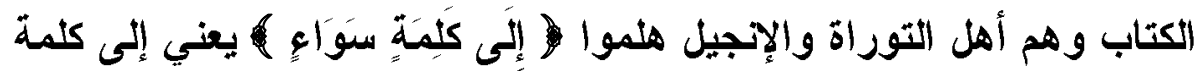
عدل هي أن نوحد الله تعالى ولا نشرك به شيئا، فإن أعرضوا عما دعوتهم إليه من الكلمة العواو، فلم يجيبوك إليها، فقولوا أيها المؤمنون للمتــولين عن ذلك: اشهدوا بأنا مسلمون(")، فناظر المسلمون أهل الكتاب في جو من الحرية والأمن الفكري السليم البعيا عن الغلو والتطرف والتثدد.

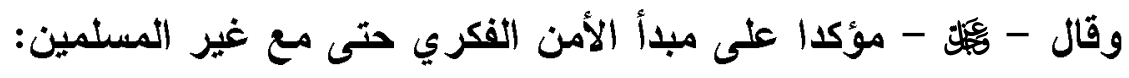

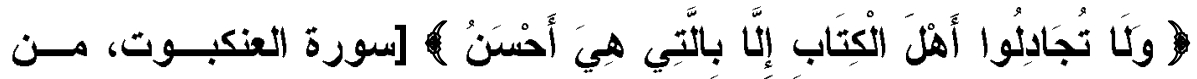
الآيـة: جـ؛]، أي لا تجادئوا أهل الكتاب إلإبالجميل من القول، وهو الــدعاء إلى الله بآياته، والتنبيه على حجبه (r).

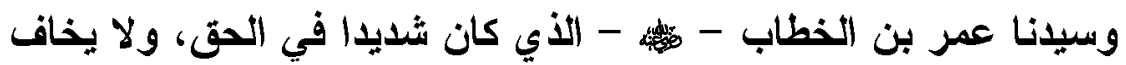
فيه لومة لائم، حينما جاءه قدامة بن مظعون مستبيحًا شرب الخمر مستدًّا

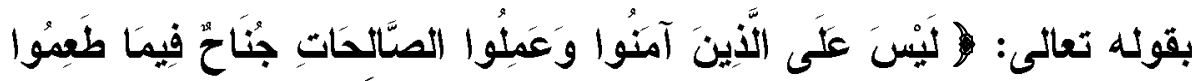

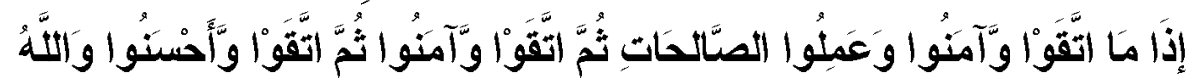

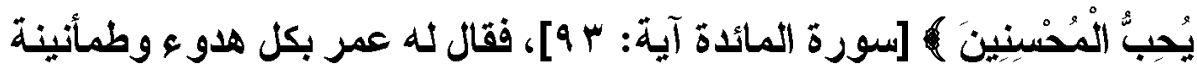

$$
\begin{aligned}
& \text { تفسير الطبري: ه / }
\end{aligned}
$$

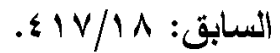


وسماحة: "أخطأت التأويل، إن اتقيت الله اجتبت ما حرم الله عثيك"(1). هكذا كانت المناظرات بين الحق والباطل؛ وهكذا كان تصــرف ســلفنا الصالح مـع من يريد أن يتثف أفكارهم بأوهام وتأويلات خاطئة للنصــوص الشر عية. ومما يؤكد حماية سلفنا الصالح للأمن الفكري، ونبذ ما يعرف بالإرهاب

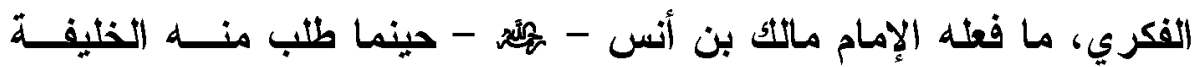
العباسي (أبو جعفر المنصور) - مئّة - أن يحمل الناس على العمل بكتابه (الموطأ)، وأن ينسخ نسخا ثم يبعث بها إلى كل مصر من أمصار المسلمين، ويأمرهم أن يعملوا بما فيه لا يتعدون إلى غيره، ويدعون ما سوى ذلتك من هذا العلم المحدث؛ لأن أصل العلم رواية أهل المدينة وعلمهم، فما كان من

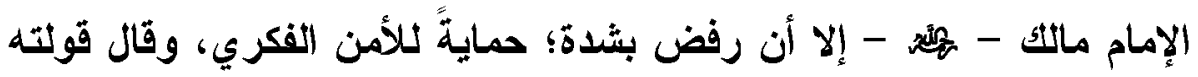
الثهيزة: " با أمير المؤمنين، لا تفعل، فإن الناس قد سبقت إليهم أقاويــل، وسمعوا أحاديث، ورووا روايات، وأخذ كل قوم بما سبق إليهم، وعملوا به،

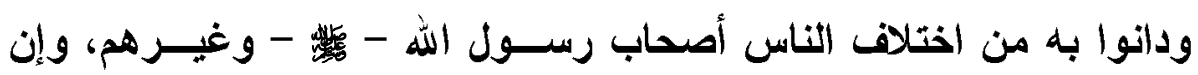

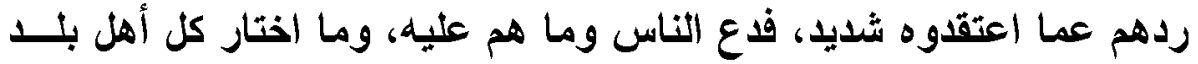

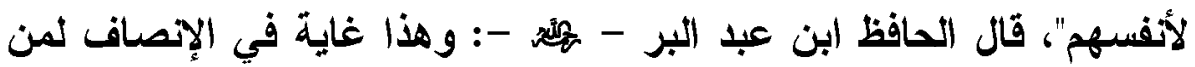

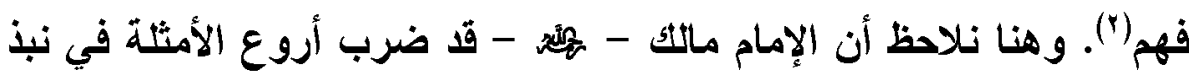
الإرهاب الفكري، والحجر على الناس في أفكارهم ومعتقداتهم.

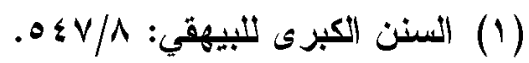

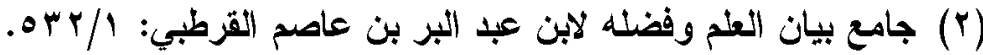




\section{الاطلاب الثاني

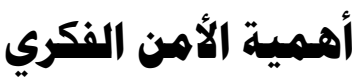

تعتبر الحاجة إلى الأمن الفكري حاجة ماسة؛ وذلك ثلأسباب الآتية: ا. يعتبر الأمن الفكري ركيزة هامة وأساسية في حياة الثعوب، ومقياســا لتقلام الأمم وحضارتها على مر العصور، فهو سبيل من سبل بلوغ الأمم

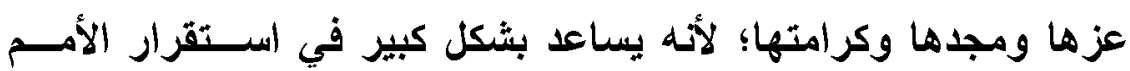
وبالتالي فهو يعمل على ازدهارها وتقدمها في جميع المجالات، ويجعل

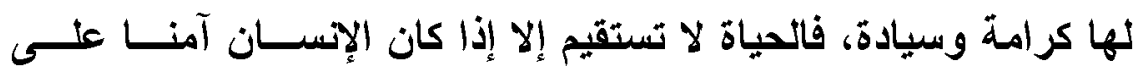
نفسه، وأهله، وماله، وكل ما بخصه، واستقامة الحياة بالنسبة للإِسان متوقفة على أمنه الفكري. r. إن الأمن الفكري هو الأي يحمي المجتمعات ويحفظها من الوقوع فـي

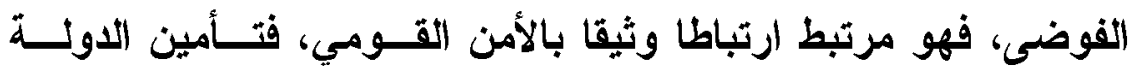
والحفاظ على قوتها الاقتصادية والاجتماعية والعسكرية و العياسية ... وغيرها لا يتحقق كليا إلا بتحقيق الأمن الفكري، فحماية الأمن الفكري

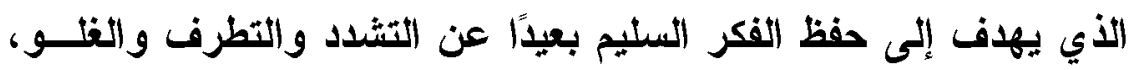
إنما يمثل بعدا استراتيجيا للأمن القومي، لأنه من المعلوم أن مسن أراد

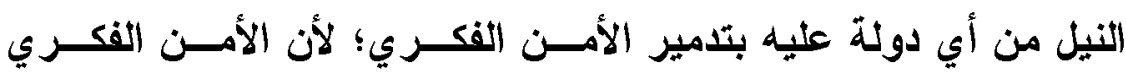
المحرك الرئيس في قوة الدول واستراتيجيتها، والحفاظ عليه يعد حفاظا على الأمن الثومي. r. يعد الأمن الفكري من أهم سبل الوقاية من الاتحر افات الفكرية، فــنحن الآن أصبحنا في مجتمع مفتوح، وأصبح العالم كالقرية الصغيرة؛ بسبب الأب 
التطور التكنولوجي الهائل في وسائل الاتصال المختلفة، وأصـبح مــن

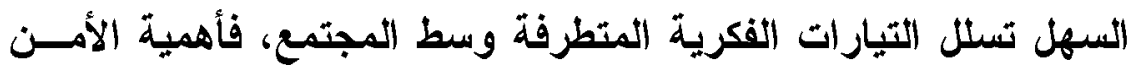

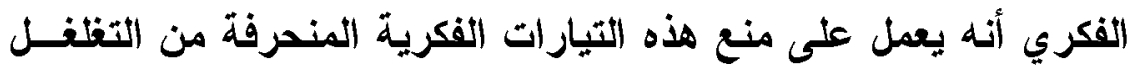

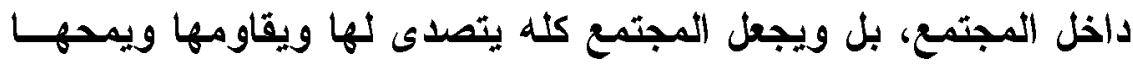

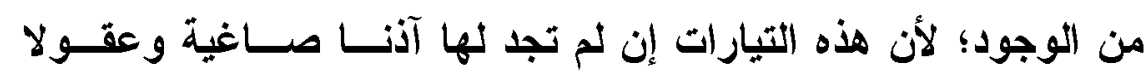
منصتة فستتلاثى للأبد.

ـ. إن الأمن الفكري يحمي المجتمعات من الإرهاب والجرائم، فحماية عقول

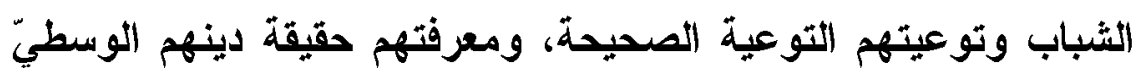
البعيد كل البعد عن التطرف والتثند والمغالاة، يساعد في القضاء على الانحر اف الفكري.

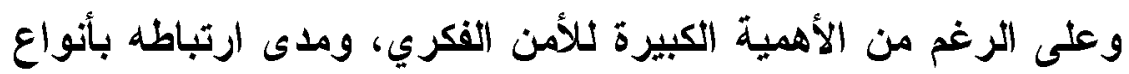

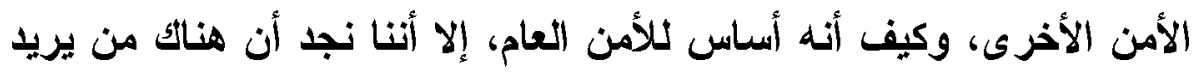

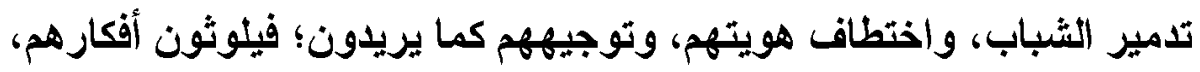
ويسيطرون عليهم، ويزرعون باخلهم الأفكار الهـامة التدميرية، التي تأكل

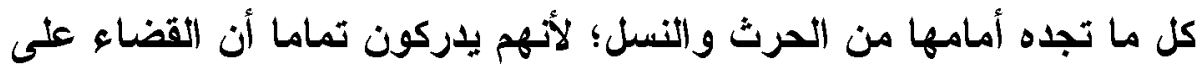
أي بلا والنيل منها يكون عن طريق تدمير عقول الثباب، وسرقة أفكارهم واستبدالها بأفكار أخرى موجهة تخدم فكرهم المتطرف عن الهدّاّم.

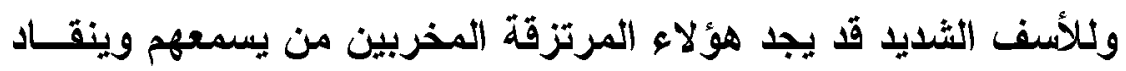

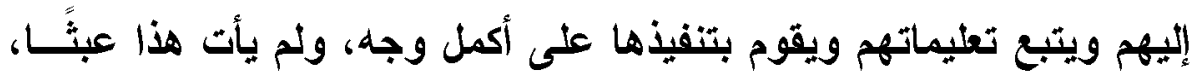

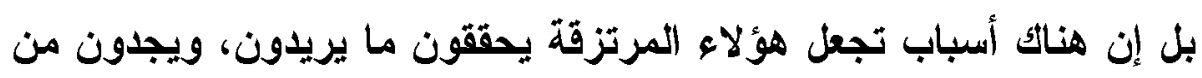
يبحثُون عنهم، وهذا ما يسمى بالاتحر اف الفكري. 


\section{الإطلب الثالث}

\section{أسباب الانشراف الفكري}

مما لا شك فيه أن الاتحر اف الفكري هو مكمـن الثــرور، ومصـــر الإرهاب والفساد عثى مر العصور، فمنه تنطلق الأقكار الهـامة التي تــدفع الناس نحو التخريب والتدمبر، فإذا صلح الفكر اندفع الناس إلى الإصــلاح

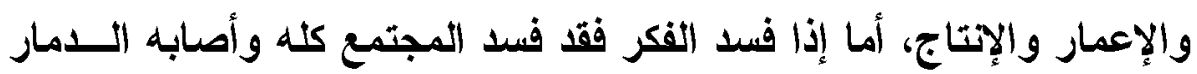
و التخريب - والعياذ بالله - فكل المصائب والانتكاسـات تأتي من الاتحــراف الفكري، وأسباب الاتحراف الفكري كثيرة ومتنوعة منها: أســباب دينيــة، وأسباب اجتماعية، وأسباب تربوية، وأسباب اقتصادية، وأسباب سياسـية ... وغيرها، وقد أوجزت هذه الأسباب في النقاط التالية: 1. انتشار فوضى الفتاوى العثوائية، وهؤلاء المنتسبين إلى الدين، الـــنين يثوهون أسماعنا ليل نهار بفتاوى فوضوية لا علاقة لها بالداين، نابعة من هوى أنفسهم؛ لتخدم أفكار هم ومعتقداتهم ونواياهم السيئة، وهؤلاء

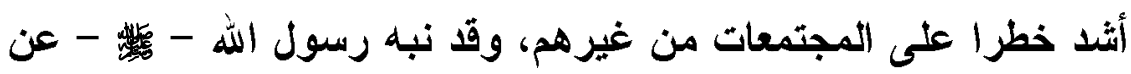

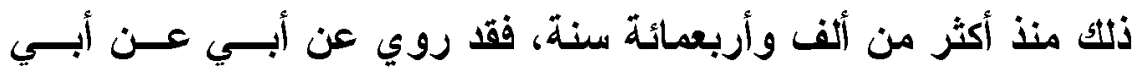

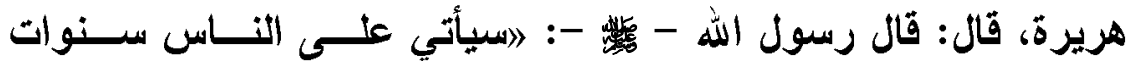

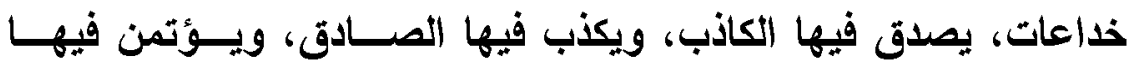

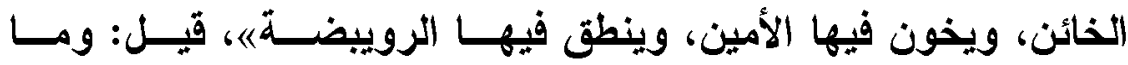

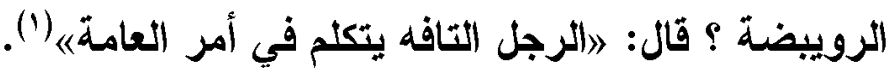

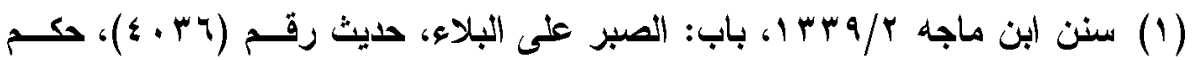

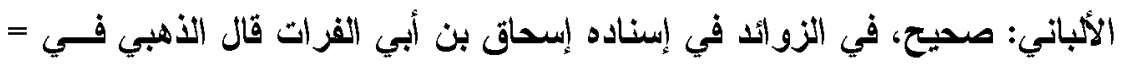

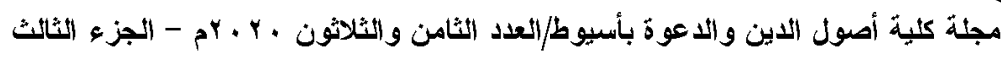




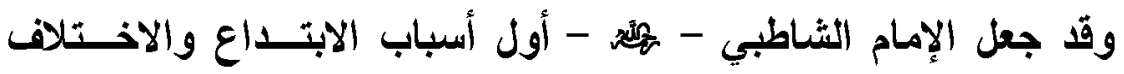
المذموم المؤدي إلى تفرق الأمة وتمزقها أن يدعي الإنسان أنه مــن أهـل الإنل

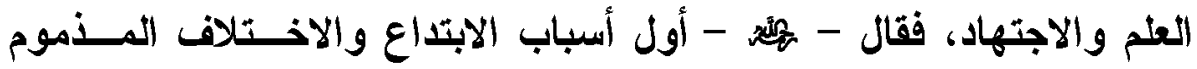

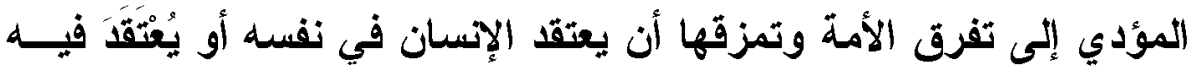

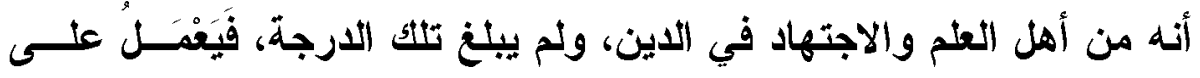

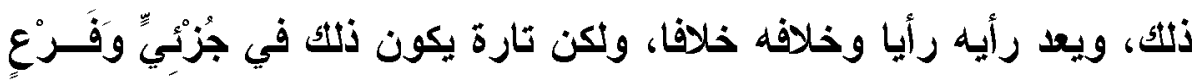

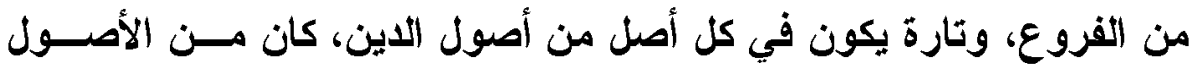

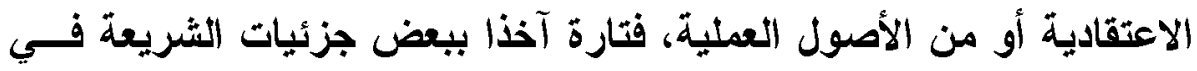

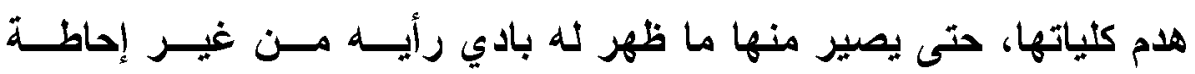

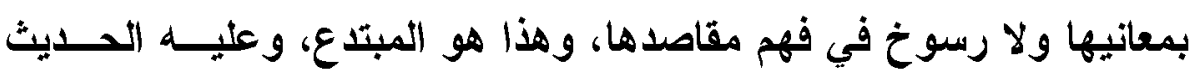

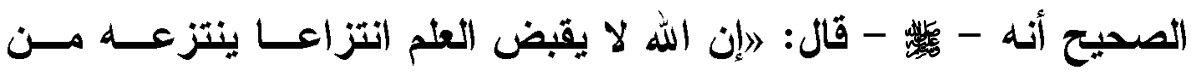

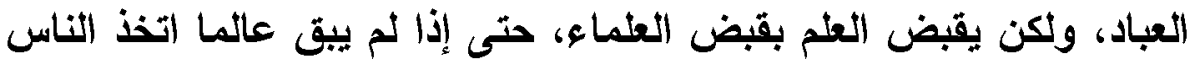

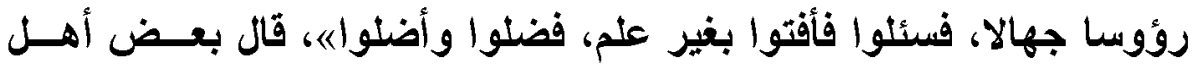

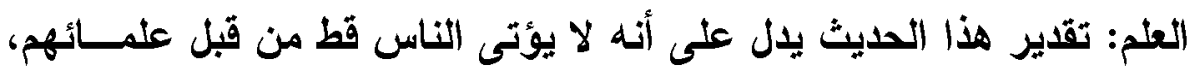

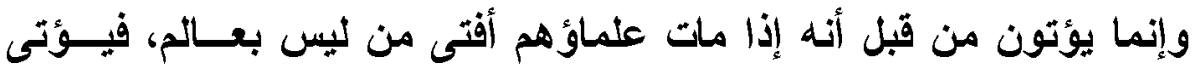

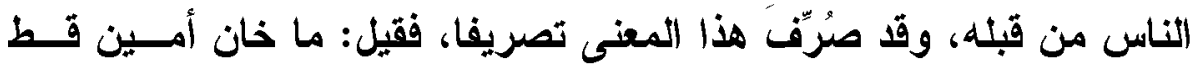

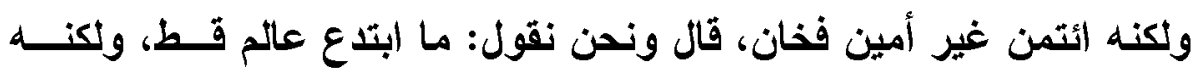

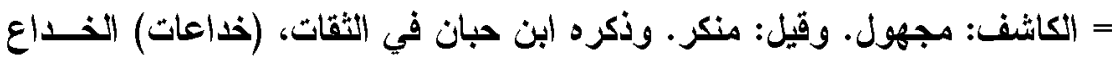

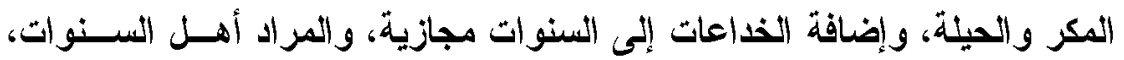

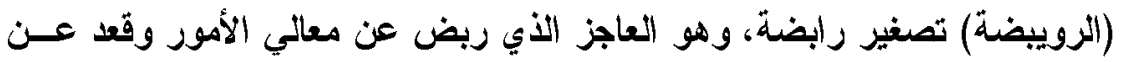

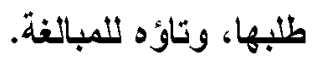

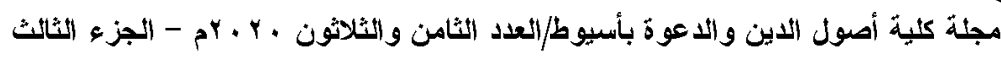




\section{استقتي من ليس بعالم (1).}

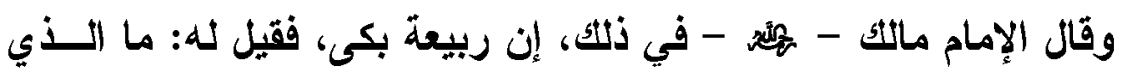

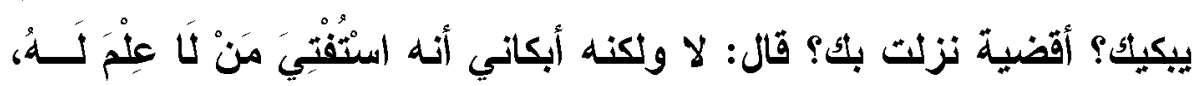

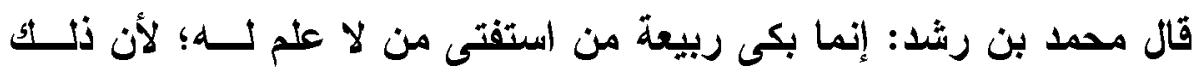
مصيبة في الاين، وهي أعظم من المصيبة في المال(r).

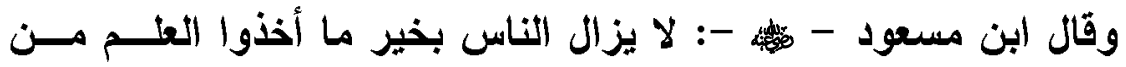

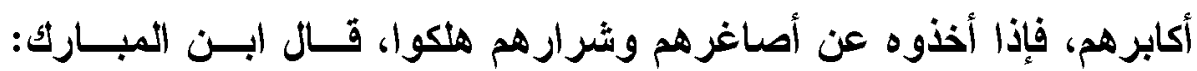

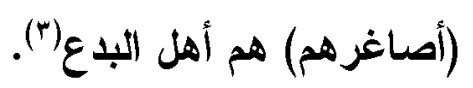

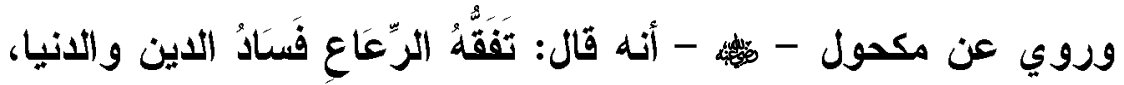

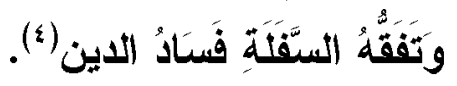

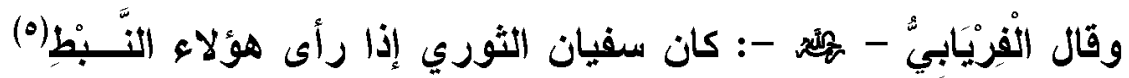

يكتبون العلم تغير وجهه، فقلت: يا أبا عبـــ الله! أرالك إذا رأيسـث هــؤلاء يكتبون العلم يثتد عليك، قال: كان العلم في العرب وفي سادات الناس، وإذا

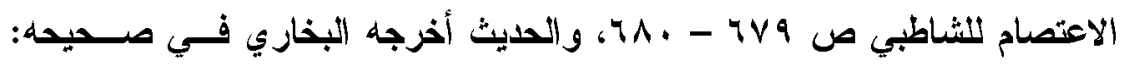

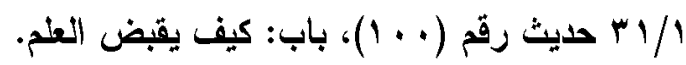

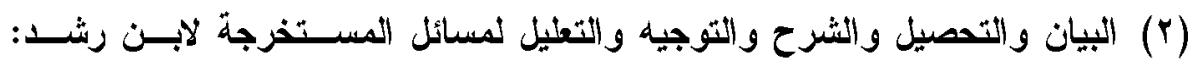

$$
\begin{aligned}
& .1 r-11 / 1 \mathrm{~V}
\end{aligned}
$$

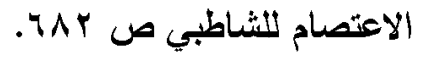

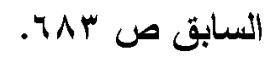

(ه) النبط: الماء الأي ينبط من قعر البئر إذا حفرت، والجمع أنباط ونبوط، والاستنباط:

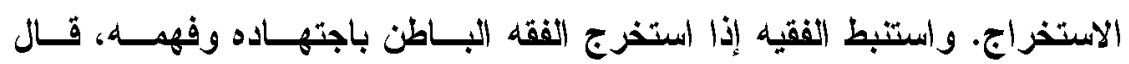

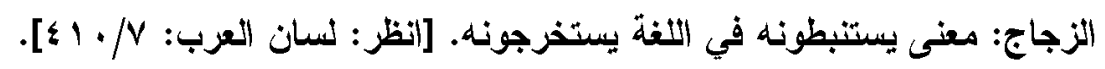

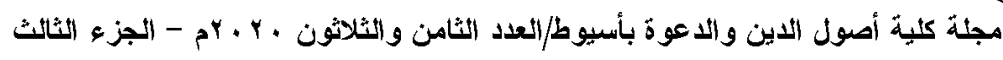




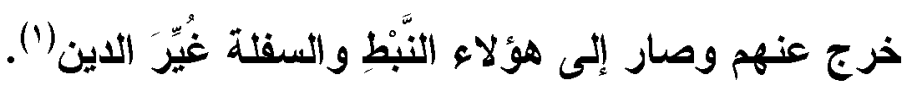

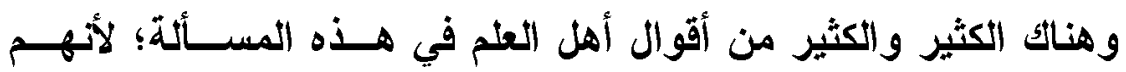
يدركون مدى خطورتها على المجتمع، فالفتوى بغير علم قد تحرم حلالا أو هن تحل حراما، والناس بطبيعتها تميل إلى أهل الاين، فيكون خطر هؤلاء على بلى بلى المجتمع أثند خطرا من الغزو الخارجي؛ لأن الغزو الخارجي معلوم للجميع،

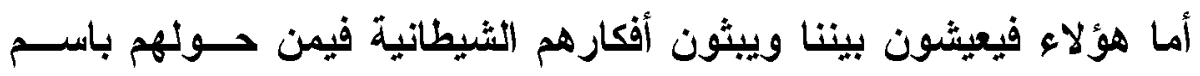
الاين دون أن يشعر بهم أحد، فهم بذلك أثثد خطرا عثـى المجتمــع مــن فئن غير هم. r. من أسباب الاتحراف الفكري أيضا: الفهم الخــاطئ لــبعض نصــوص الاين، فأصبح الجميع مفسرين، وكل مفسر يفسر كما يريد، وعلى هواه

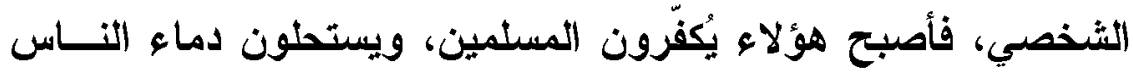
وأموالهه، ويقومون بالتدمير والتخريب تحت مسمى الإصدلاح وإقامـــة شرع الله، وشرع الله بريء منهم ومن أفعالهم؛ لأن شرع الله لا يدعو

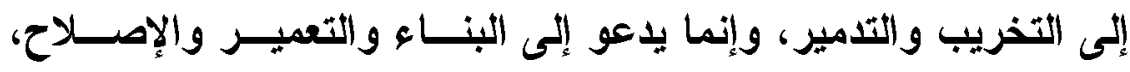

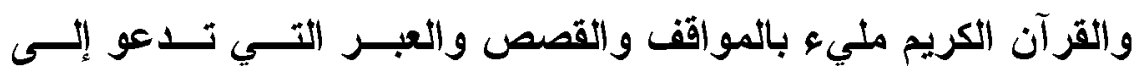

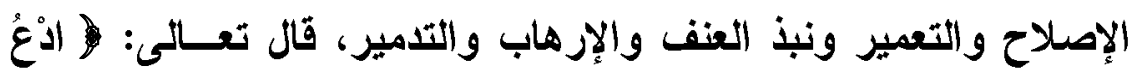

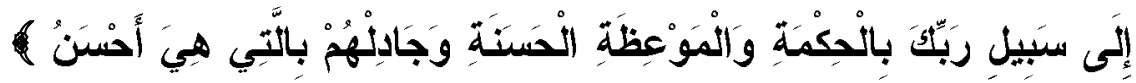

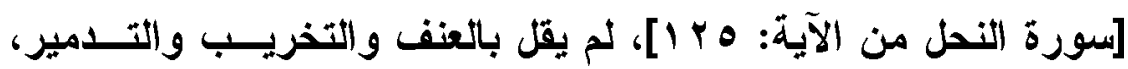

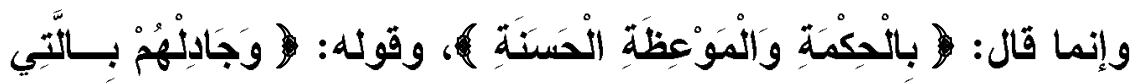

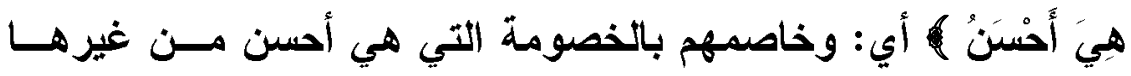


وهي أن تصفح عما نالوا به عرضك من الأذى (')، وقال تعـالى عنـى

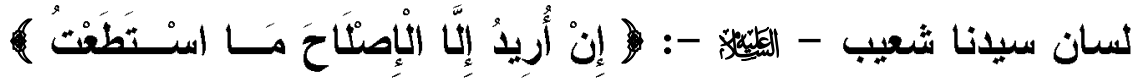

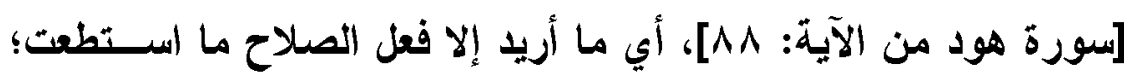
لأن الاستطاعة من شروط الفعل (r) .

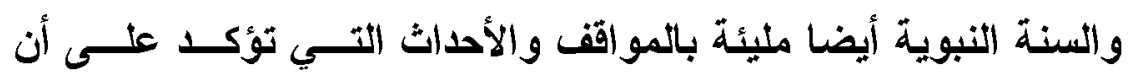

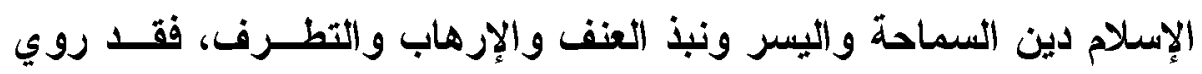

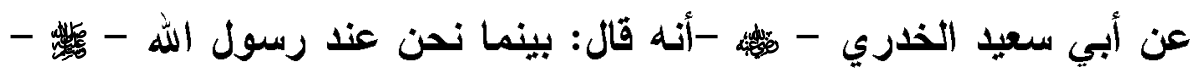
وهو يقسم قسما، أتاه ذو الخويصرة، وهو رجل من بني تميم، فة فــال: يــا

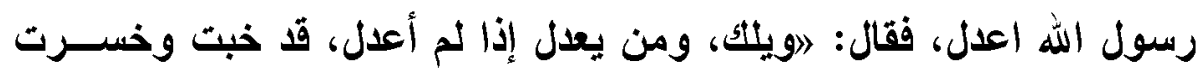

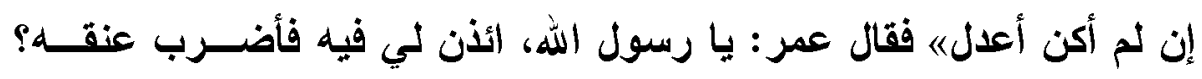

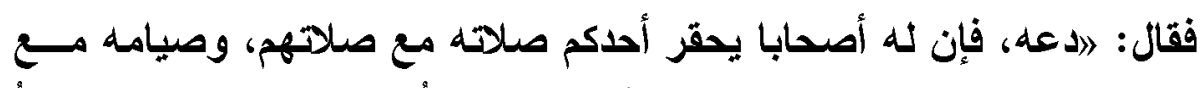

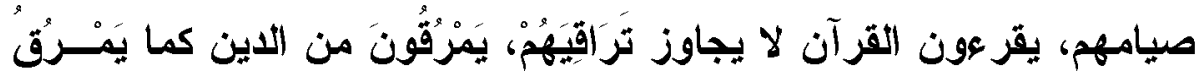

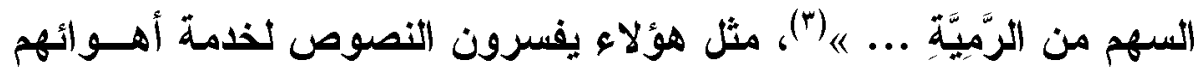
وأفكارهم الخاطئة، فيكفروا هذا، ويستحلوا دم هذا، ويجيزوا سرقة أمسـوال هولئ

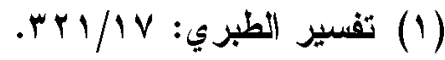

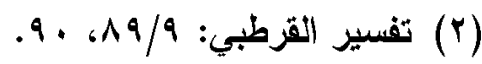

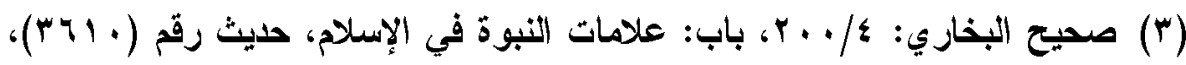

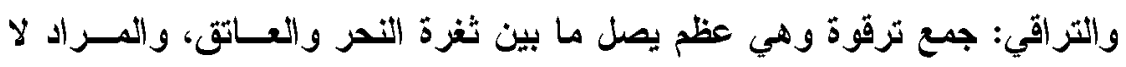

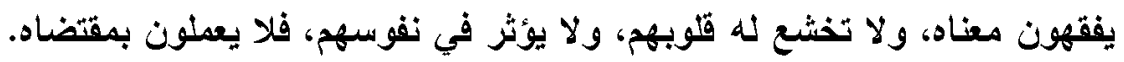

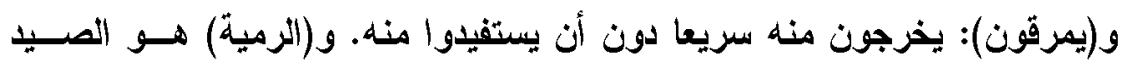

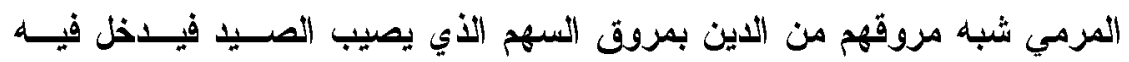

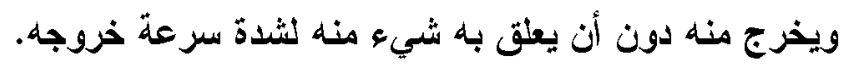


هذا ... وغير ذلتك، كل هذا تحت شعار الاين، وتفسيرهم الخــاطئ لــبعض النصوص، ومثل هوُلاء إنما بشوهون صورة الاين، والاين بـريء مــنهم ومن أفعالهم .

r. الاعتماد على بعض التصوص وترك بعضها، فمن المعثــوم أن مــنهج

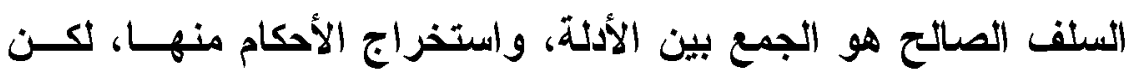
هؤلاء المرتزقة يعتمدون على بعض التصوص التــي تخــــم أفكـارهم

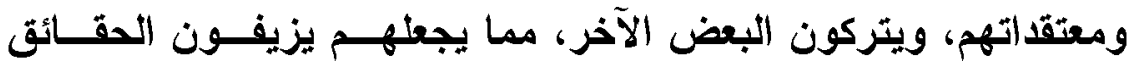
ويوهمون التاس بأن ما يعتقدونه هو الدين الصحيح، وما دونه تضليل، وقد ورد في السنة بإسناد حسن عن عمرو بن شعيب عن أبيه عن جده -

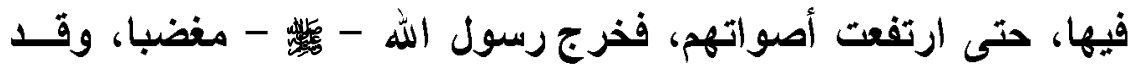
احمر وجهه، يرمبهم بالتراب، ويقول: 》 مهلا يا قوم، بهذا أهلكت الأمم

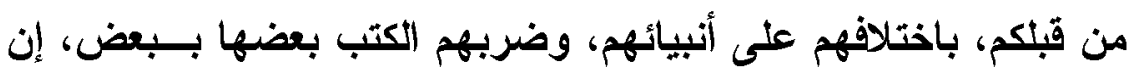
القر آن لم ينزل يكنب بعضه بعضا، بل بصدق بعضه بعضا، فما عـرفتم

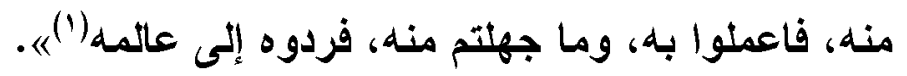
؛. التثدد في الأحكام، والإسراف في إطلاق التحريم في الفتــاوى؛ وهـــا التحريم المبالغ فيه خلق نوع من الكبت عند بعـض التــــاس، وســاهم بشكل كبيز في انحراف أفكارهم، فالاين سمح بعيد كل البعد عن التشدد والتعصب والمغالاة، والأدلة على ذلك كثيرة ومتعـددة، قـال تعسالى:

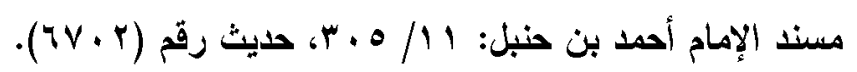




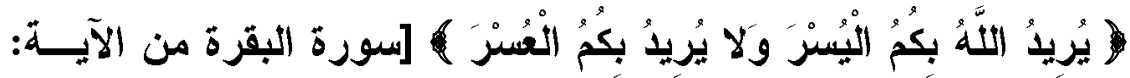

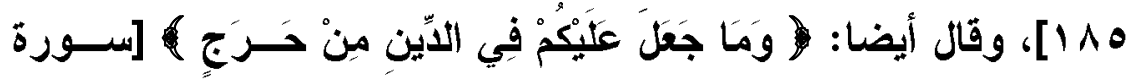

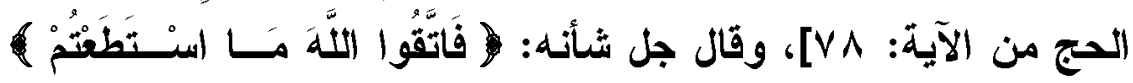

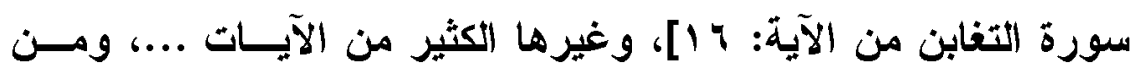

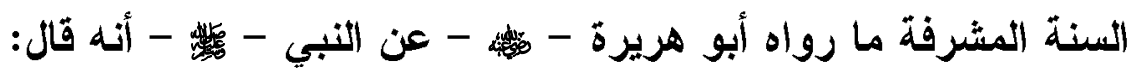

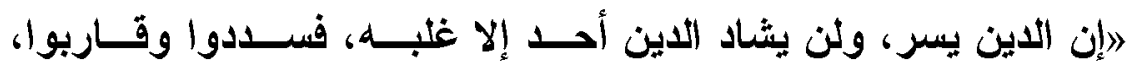

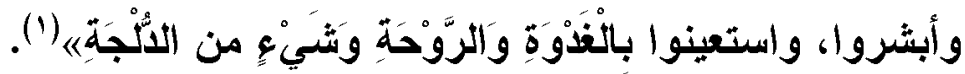

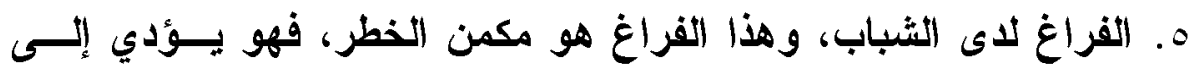

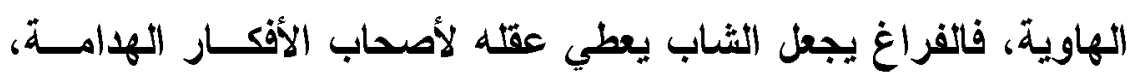

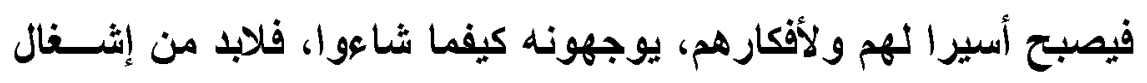

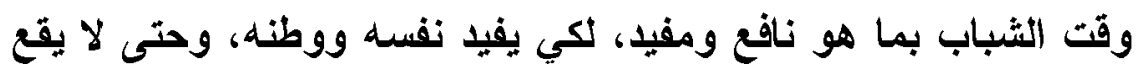

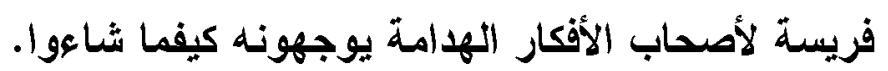

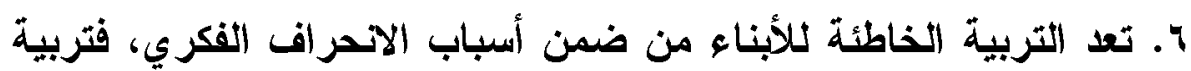

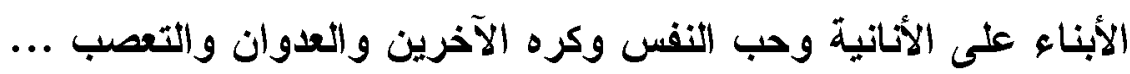

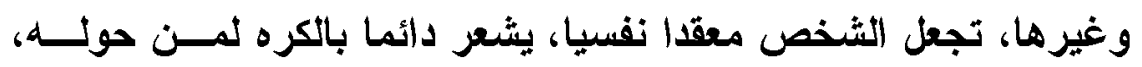

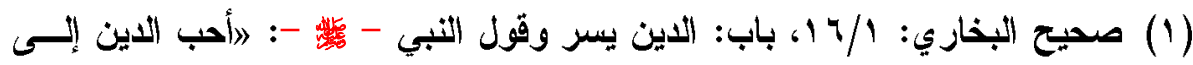

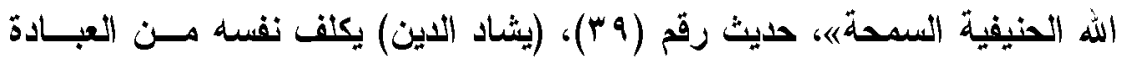

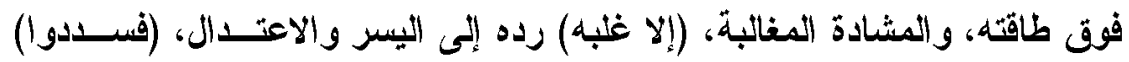

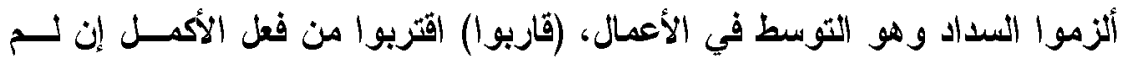

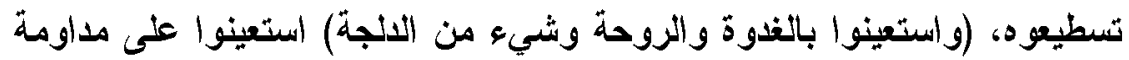
العبادة بإيقاعها في الأوقات المنثطة كأول النهار وبعد الزوال وآثر آلخر الليل.

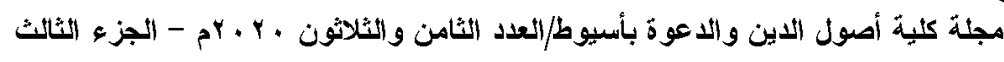


يرفض قبول الر أي الآخر ...، هذه التتشئسة السيئة تعد أساس الاتحر اف الفكري؛ لأن الثخص بهذه الصفات يكـون لايـــه الاســتعداد الكامـلـ لاتحراف أفكاره وتوجهها التوجيه السبئ، خاصة إذا كاتت هذه الأفكــار المنحرفة تتوافق مع البيئة التي نشأ فيها، وهذه التربية الخاطئة بالطبع بعيدة كل البعد عن التربية الإسلامية الصحيحة، فالإسلام لا ياعو إلـى الأنانية أو كره الآخرين أو التعصب أو العدوان ...، بل إن الإسدلام دين

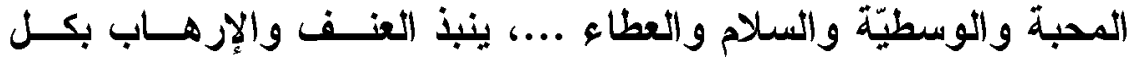
أتثكاله ووسائله، دين سهل بسيز بعيد عن التثندد والتعقبد، جعـل الله

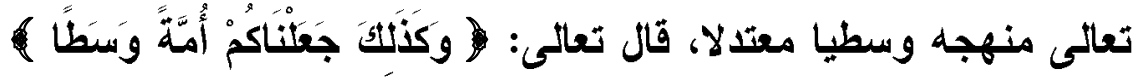
[سورة البقرة من الآية: بـ 1 ]، وسطا في العقيدة والعبادة والمعاملــة

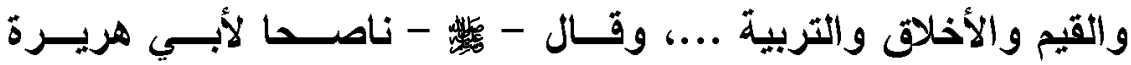
-

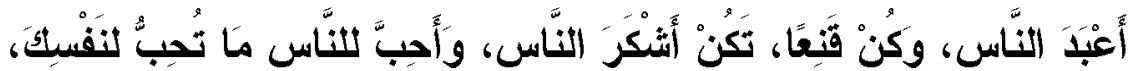

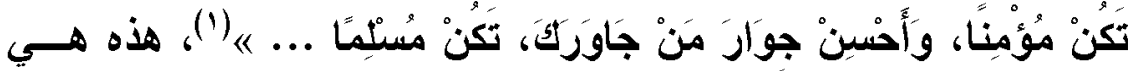
التربية الإسـلامية التي يلعو إليها الإسلام، بعيدة عن الـبغض والكــره والحقد والأذى.

V. من أسباب الاتحر اف الفكري أُبضا: غياب الرقابة الاجتماعيــة، فغيــاب الرقابة الاجتماعية يعد من أهم أسباب الاتحراف الفكري، فالعـالم الآن أصبح قرية صغيرة، والمجتمع أصبح مفتوحا دون قيود أو حدود، وترك

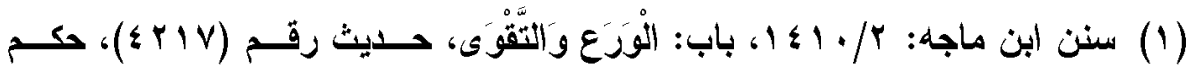
الألباني: صحيح إن مصن

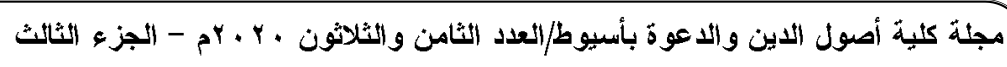


التشه دون مراقبة يجعله أسبرا لأصحاب الأفكار الكهامــة، يوجهونــهـ كيفما شاعوا.

ᄉ. أيضا الفقر والبطائة والظروف الاقتصادية والاجتماعية السيئة من أهم أسباب الاتحراف الفكري؛ وذلك لأن هذه الظروف قا تُضعف الاتتمــاء الوطني لاى الثباب، مما يجله بيحث عن مصدر آخر لتحسين ظروفه المعيثية السيئة، فيستغل هؤلاء المرتزقة هذه الظروف ويبدعون فـي هي تخريب عقول هؤلاء الثباب، فيحرضونهم ضد أوطـانهم، ويزرعـون باخثهم الكره و الحقد لأوطانهم، مستخلين الفوارق بين الطبةــات فــي المجتمع الواحد، ومن المتعارف عليه أن هذه الظروف العيئة هي أحد العوامل الأساسية في الانحر اف الفكري والسلوكي. 9. كثرة الصراعات السباسية والطائفية والقبلية في البلد الواحد؛ مما يجعل الثباب يتجهون لمن بعتقدون أنهم الملاذ والملجأ، فيرتمون في كنفهم، وهؤلاء يبدعون في استقطابهم وتوجيههم كيفما شاعوا. • ا.الاستخدام الخاطئ لوسائل الاتصال الاكتروني، فنحن الآن أصبحنا أمسام ثورة تكنولوجية هائلة، وتقدم اتصالي غير مسبوق، وقد يستفل هؤلاء المرتزقة سهولة الاتصال فيقتحمون عالم الثباب ويبثون أفكارهم الههامة بكل سهولة، وللأسف قد يقنعون بعض هؤلاء الثباب بأساليبهم

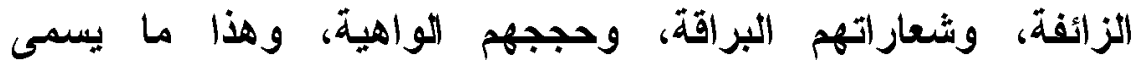
بـ "الإرهاب الاككتروني"، وهذا النوع من الإرهاب أُثد انواع الإرهاب خطورة، لأنه ياخل كل بيث وفي أي وقت دون رقابة، فأصبح من السهل السيطرة على عقول الشباب عن طريق هذه الوسائل. 
هذه هي أسباب الاتحراف الفكري الأي يؤدي إلى تـــمير المجتمعسات

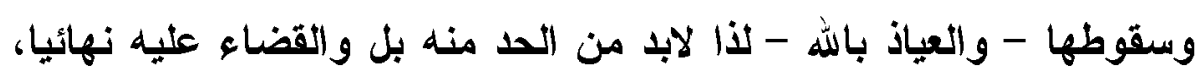

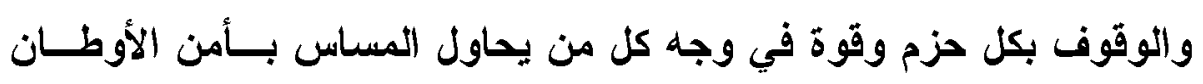
واستقرارها، وهذا لا يتأتى إلا بعلاج أسباب هذا فئ الانحراف، وحماية العقول

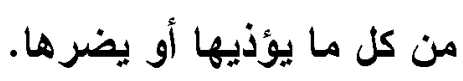




\section{الإطلب الرابع \\ وسائل هماية الأهن الفكري}

إن منافذ الغزوو الفكري واسعة وكبيرة، أوسع مــن أن تــــ بـالطرق

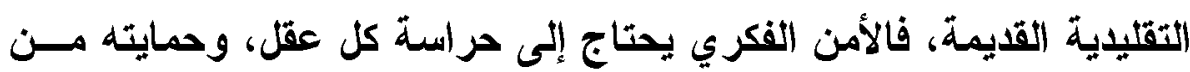
الاختراق قدر الإمكان، والتعلاج الناجح للاتحر اف الفكري يكمن فـي عــلاج أسبابه ودوافعه، وذلتك على النحو التالي: 1. أصبحت الآن الحاجة ماسة إلى تصحيح بعض المفاهيم الخاطئــة التــي انطبعت في أذهان الكثيرين عن الثريعة الإسلامية، فالثريعة الإسلامية ليست عبادات فقط أو معاملات فقط أو حدود فقط ... وإنما هي كيـان كامل لا يتجزأ، ونظرية شاملة لكل مناحي الحياة عبــادات ومعــاملات

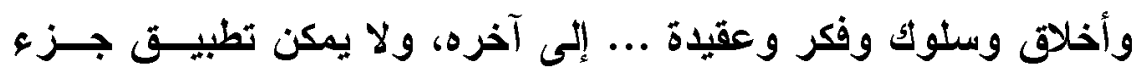

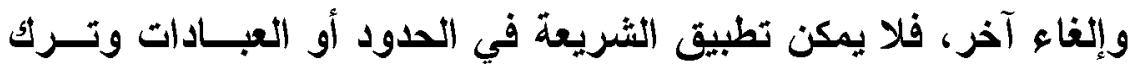

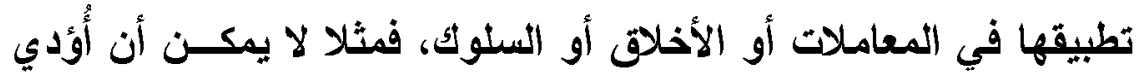
جميع العبادات من صلاة وصوم وزكاة وحج، ولم تتهني هذه العبـادات

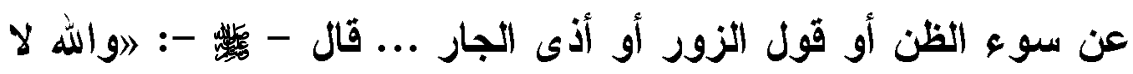
يؤمن، والله لا يؤمن، والله لا يؤمنه قيل: ومن با رســول الله؟ قــال:

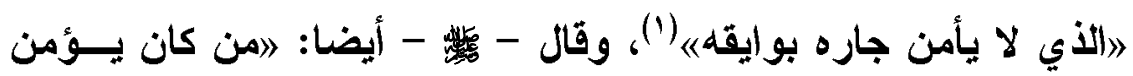

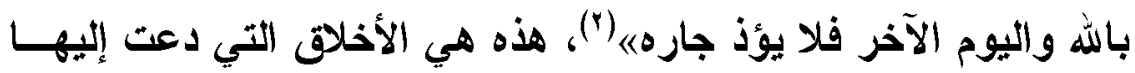
(1) صحيح البخاري: 1/ • 1، باب: إثم من لا يأمن جاره بوايقه، حليث رقم (7 1 + 7)،

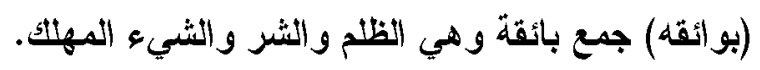

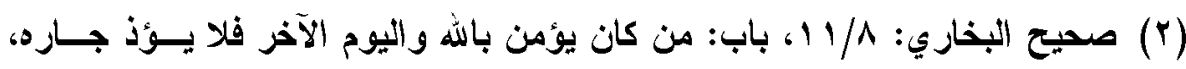

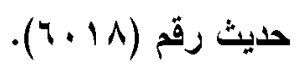


الشريعة الإسلامية، فالمقصود من العبادات تهذيب النفس وصدلاح السلوكى، فالتعبادة التي لا تنهي عن فعل الفحشاء والمنكر فليس لله حاجة بهــا؛

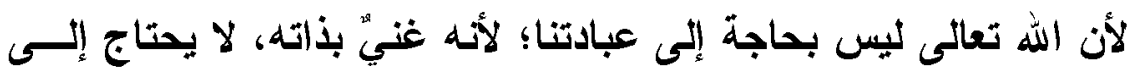
شيء مما في الوجود بل كل ما في الوجود في احتياج مستمر إلبيه، قال

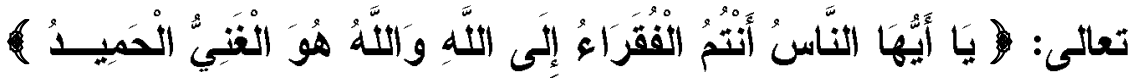
[سورة فاطر آية: ه 1]]، جاء في تفسير هذه الآية: يا أيها الناس أنـتم هـئ أولو الحاجة والفقر إلى ربكم فإياه فاعبدوا، وفي رضاه فسارعوا، يغتكم

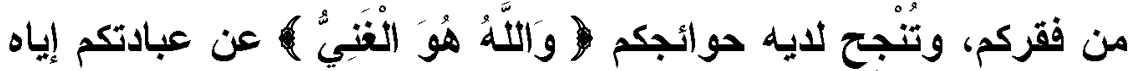

وعن خدمتكم، وعن غير ذلتك من الأثثياء؛ منكم ومن غيركم( ('). كذلك الصوم الذي لا ينهى عن الفحشاء والمنكر فليس لله حاجة في أن

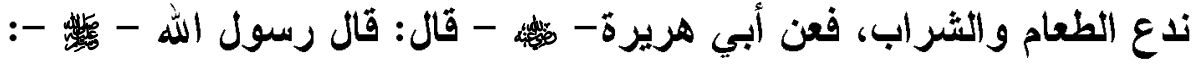

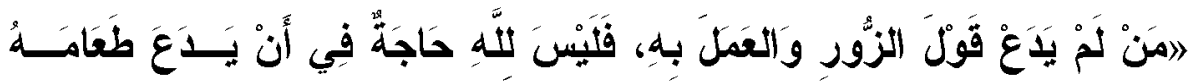

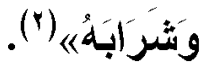

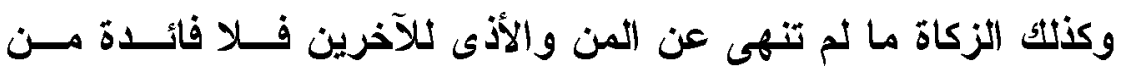

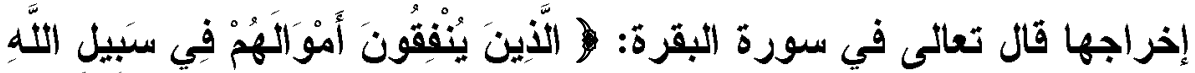

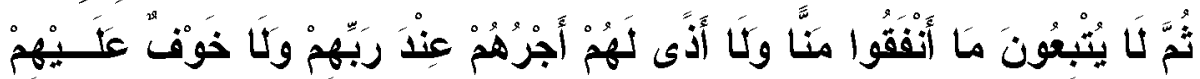

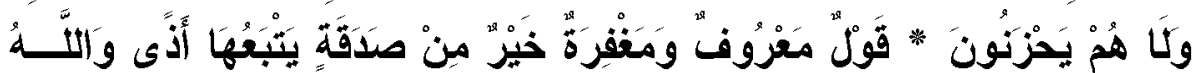

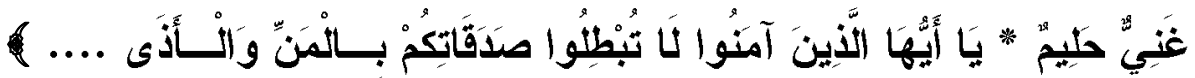

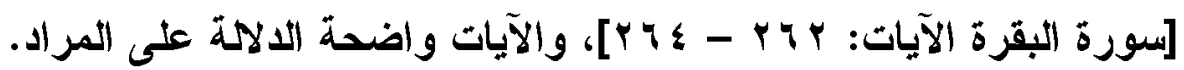

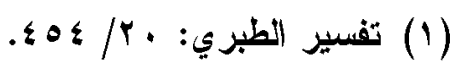

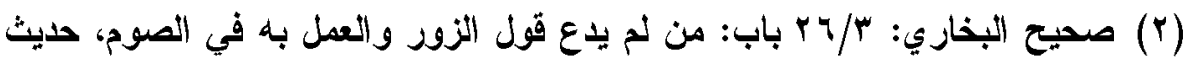

$$
\text { رقم (19.r) (19) }
$$


وأيضا الحج الأي لا ينهى عن الفحثاء والمنكر فليس الله حاجة بـه،

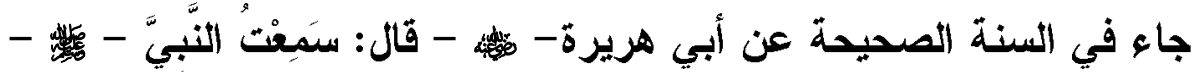

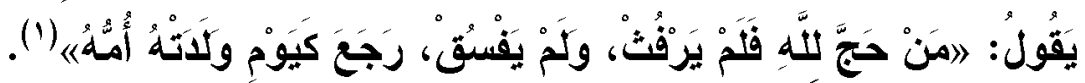

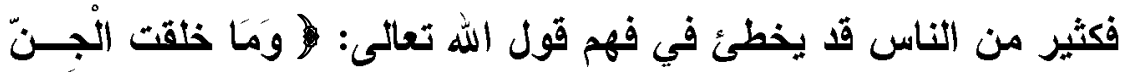

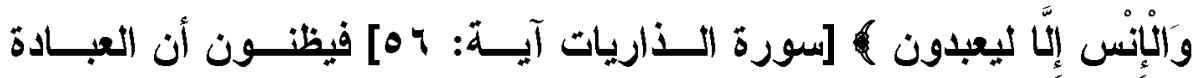
مقتصرة عثلى الصلاة والزكاة والصوم والحج والأكر فقط، ويعتقدون أنهــم إن فعلوا هذه الأثياء فقط فإنهم بذلك أقاموا الإســلام واتبعــوا تعليماتــه، والحقيقة غير ذلتك فالتبادة ليست مقصورة عثى إقامة هذه الثشعائر فحسب،

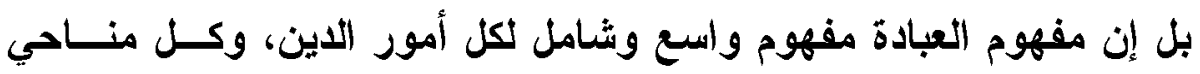
الحياة، فالإتسان يجب عليه أن يكون عبلا لله في كل وقت وفي كل مكـــان، وليس في أوقات أداء العبادات المعروفة التي لا تستغرق إلا وقتا قليلا مسن حياة الإنسان. وقد فطن شيخ الإسدلام ابن تيمية - هئهة - إلى المعنى الحقيقي للعبادة فقال: العبادة هي اسم جامع لكل ما يحبه الله ويرضاه من الأقوال والأعمال

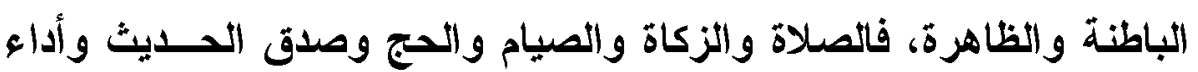
الأمانة وبر الوالدين وصلة الأرحام والوفاء بــالعهود والأمسـر بـالمعروف والنهي عن المنكر والجهاد للكفار والمنافقين والإحسـان للجـار واليتـيم

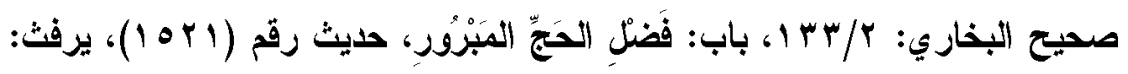

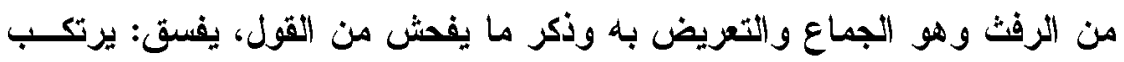

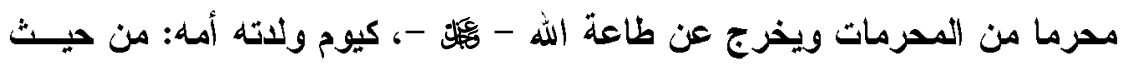
براعته من اللنوب. 
والمسكين وابن السبيل والمملوك من الآدميين والبهائم والـــعاء والـــكر و القراعة وأمثال ذلك من العبادة، وكذلك حسب الله ورســـله، وخثــية الله

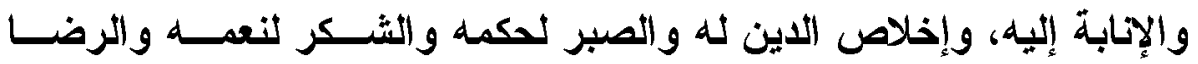
بقضائه والتوكل عثيه والرجاء لرحمته والخوف من عذابه وأمثال ذلتك هي

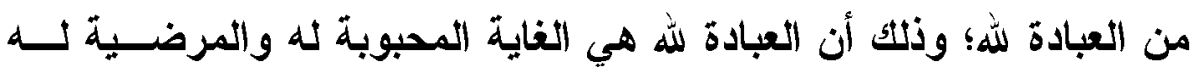
التي خلق الخلق لثها'). فالثشريعة الإسـلامية كيان كامل متكامل، كل جزء فيها مكمـل ثلآخــر، فأداء العبادات لابد وأن يكون مقرونـا بـالأخلاق والســلوكيات الإســلامية الطيبة، التي تلدعو إلى التواد والتــراحم والتعــاون والحــب والعطـاء ... وغيرها من الأخلاق الإسدلامية الراقية. ومن أمثلة الفهم الخاطئ لبعض نصوص الاين قوله تعالى في ســـورة

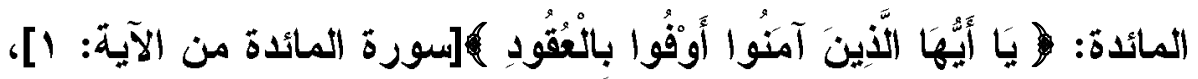
قد فهم بعض الناس أن المقصود بالعقود هنا هي العقود التجارية فقط، لكن الحقيقة أن هذا لفظ شامل لكل العهود التي بين العبد وربه، جاء في تفسيز السعدي: هذا أمر من الله تعالى لعباده المؤمنين بما يقتضيه الإيمان بالوفاء بالعقود، أي: بإكمالها، وإتمامها، وعدم نقضها ونقصها، وهذا شامل للاعقود التي بين العبد وبين ربـه، من التزام عبوديته، والقيام بها أتم قيام، وعـدم

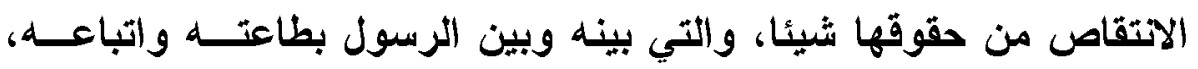
والتي بينه وبين الو الاين والأقارب، ببزهم وصلتهم، وعدم قطيعتهم، والتي بينه وبين أصحابه من القيام بحقوق الصحبة في الغتى والفقــر، واليســر 
والعسر، والتي بينه وبين الخلق من عقود المعاملات، كـالبيع والإجــارة، ونحوهما، وعقود التبرعات كالتهبة ونحوها، بل والقيام بحقوق المسلمين التي هي

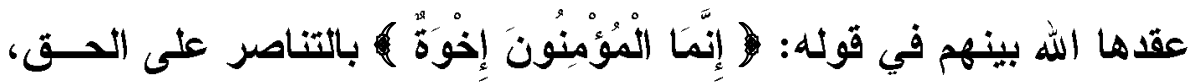
والتعاون عليه والتآلف بين المسلمين وعدم التقاطع، فهذا الأمسـر شــامل

لأصول الاين وفروعه، فكلها داخلة في العقود التي أمر الله بالقيام بهاء"). ولكي يتم هذا التصحيح لابد من الفهم الاقيق لفايات ومقاصد تشــريع

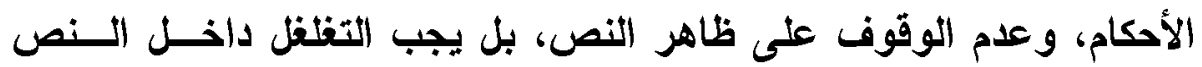
والإحاطة بأسباب النزول، ومحاولة فهم مناسبة كل قول، ولقد برع ســلفنا الصالح في ذلك فلم يقفوا عند ظاهر النص بل تغلغلوا داخله وداروا حوله، فقهموا مقاصد التثريع وغاياته النبيلة، مثال ذلتك عندما احتج مانعوا الزكاة

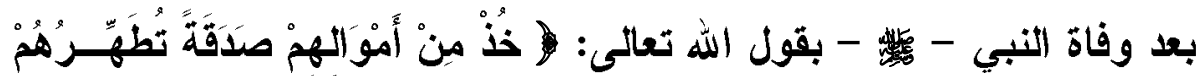

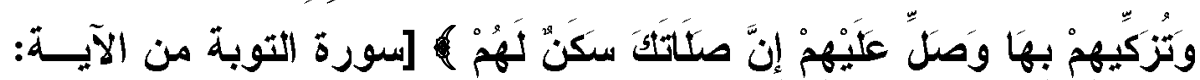

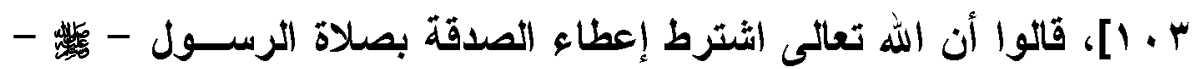

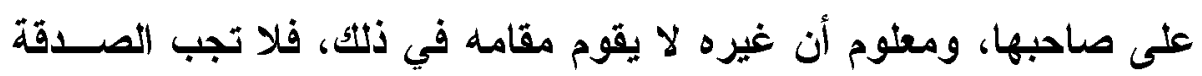
لعدم وجوده - كئد - ولم يقف الصحابة - رضوان الله عليهم - عند ظاهر النص بل تغلظوا داخله، وردوا هذا التأويل الباطل عثى أصحابه وأفهموهم

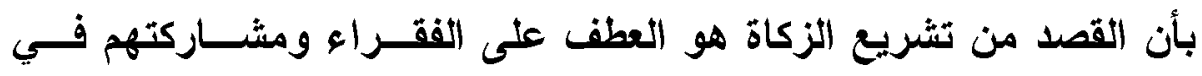
شعورهم ...، هكذا تعامل سلفنا الصاتح مع النصوص، ذم يقفوا على ظاهر النص بل فهموا المقصود من التص وتوصلوا إلى غاياته وأهدافه فهـادوا

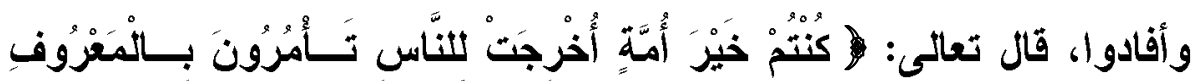

(1) تفسير السعدي المسمى ص M 1 (1) 


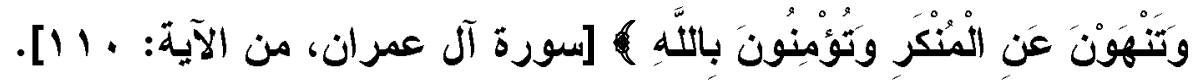

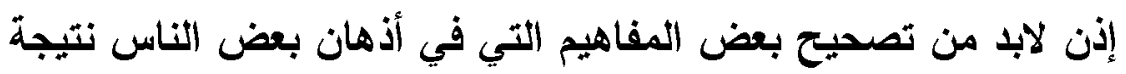

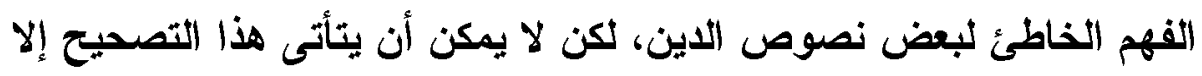

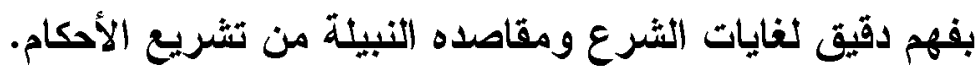

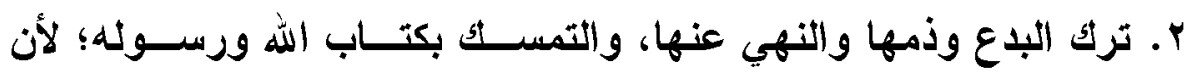

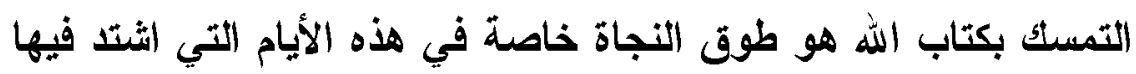

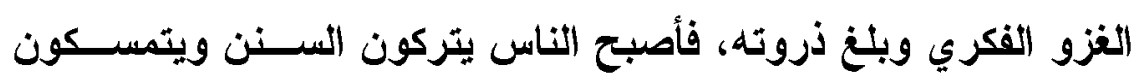
بالبدع والخرافات التي ما أنزل الله بها من سلطان، فضاعت داعت معالم الداين

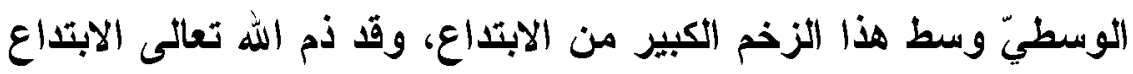

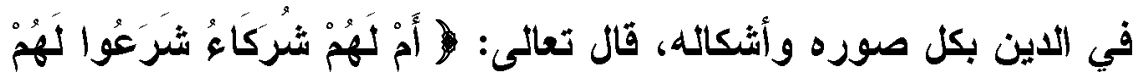

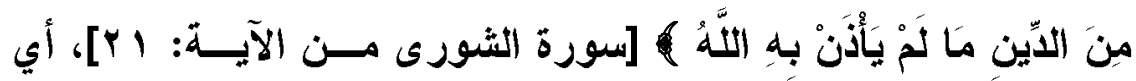

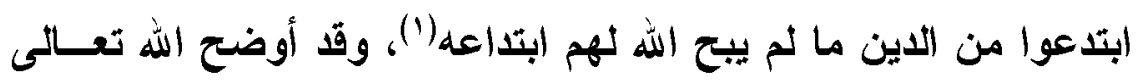

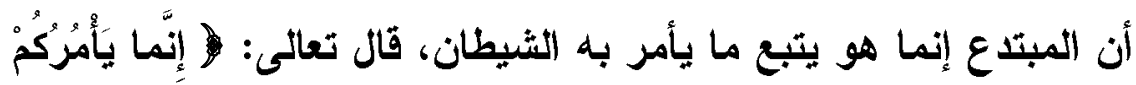

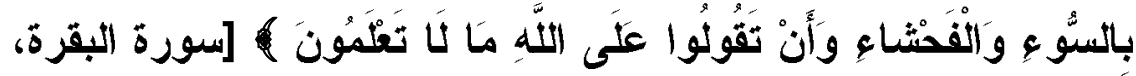

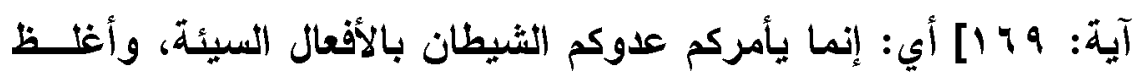

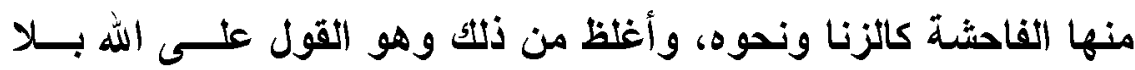
علم، فيدخل في هذا كل كافر وكل مبتدع أيضا(").

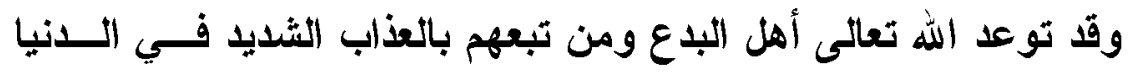

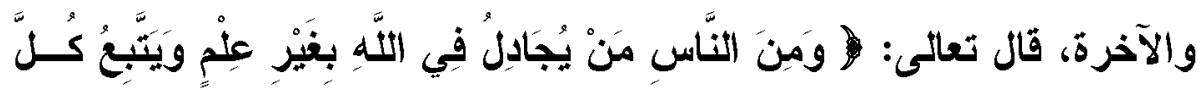

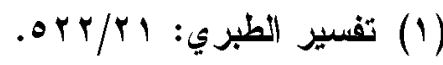

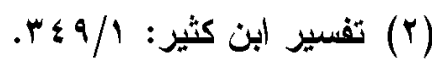

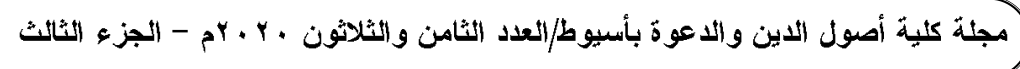




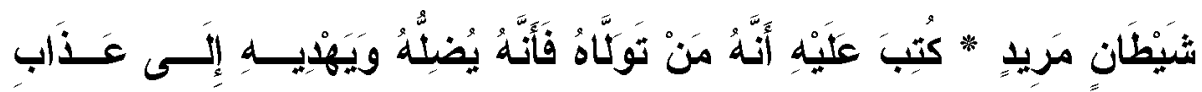

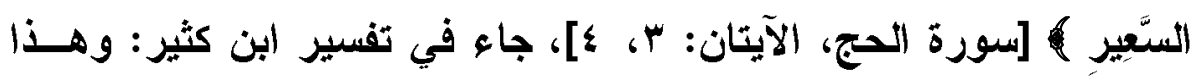

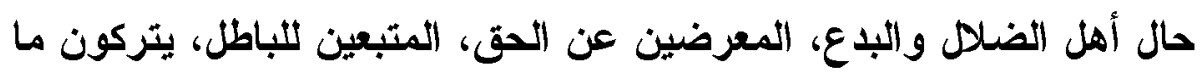

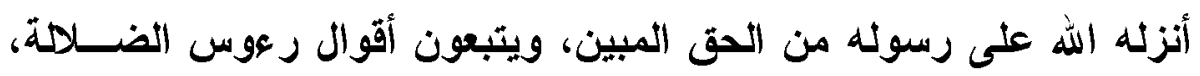

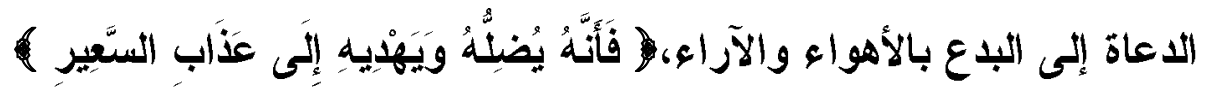
أي: يضله في الانيا ويقوده في الآخرة إلى عذاب السعير (').

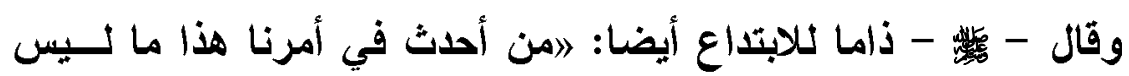

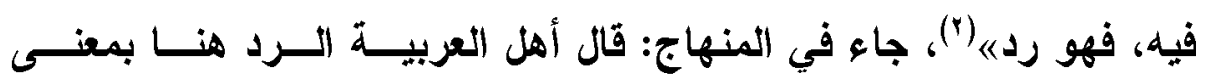

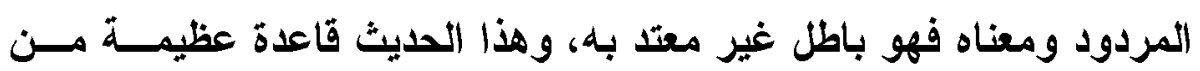

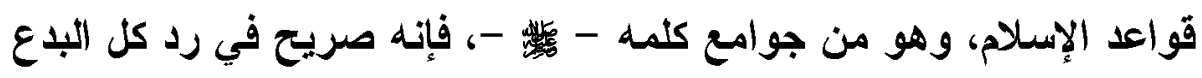
والمختر عات (").

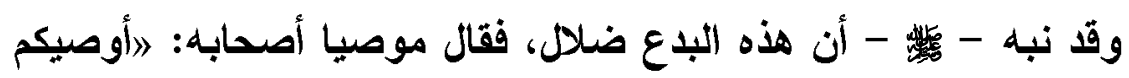

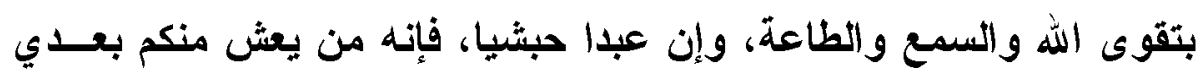

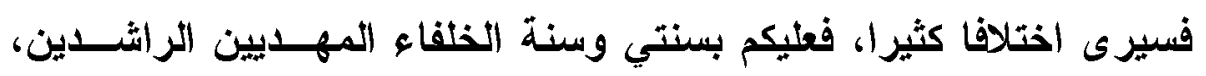

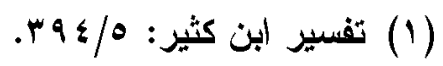

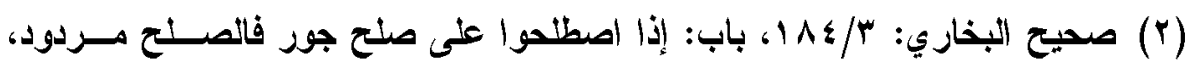

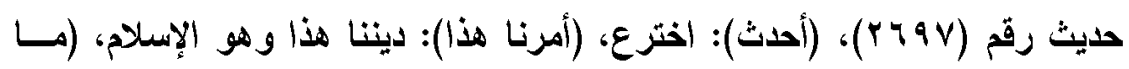

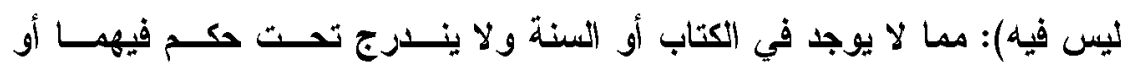
يتعارض مع أحكامها، (رد) باطل ومردود لا يعتد بهابه.

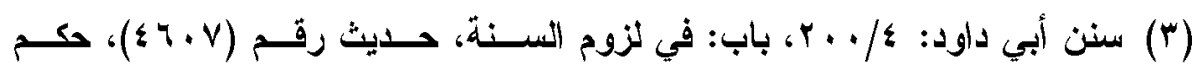
الألباني: صحيح. الي دلرد:

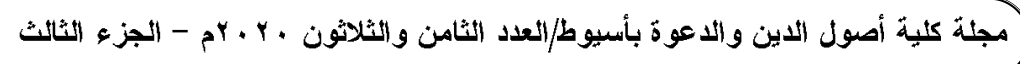


تمسكوا بها وعضوا عليها بالنواجذ، وإياكم ومحدثات الأمسـور، فــإن كـلـ

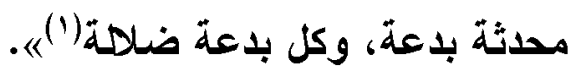

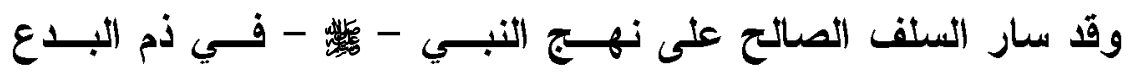

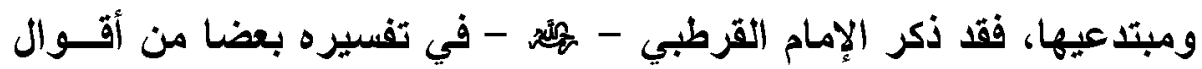

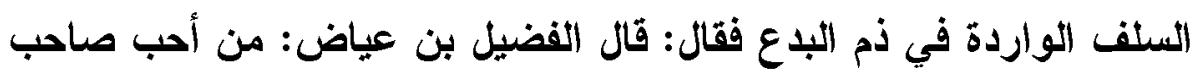

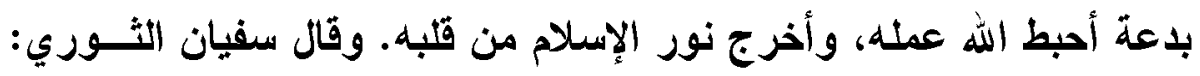

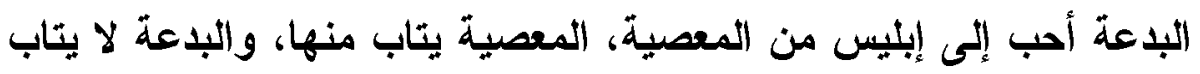

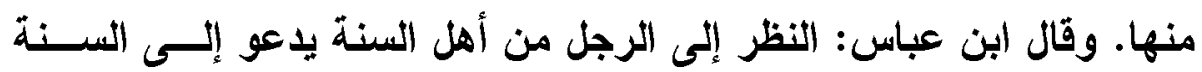

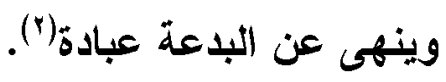

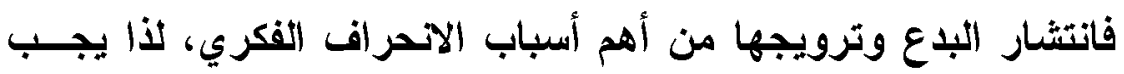

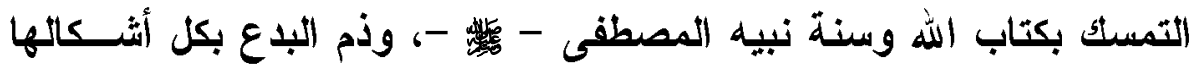

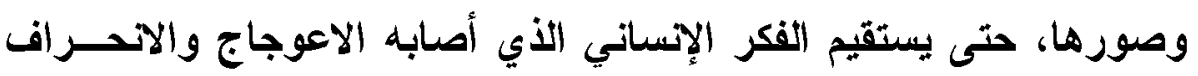

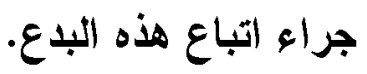
r. التحري في الفتاوى، والقضاء على فوضى الفتاوى العثوائية التي كلي كئي

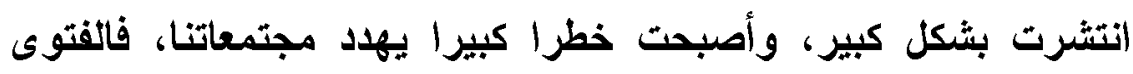

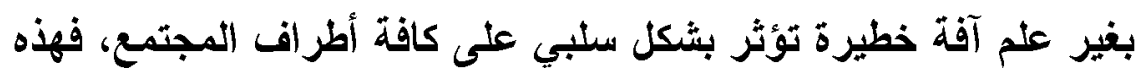

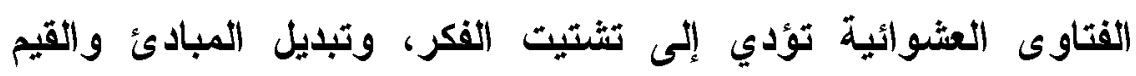

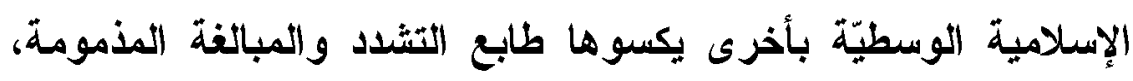

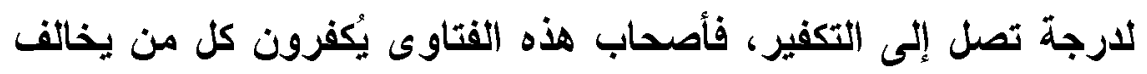

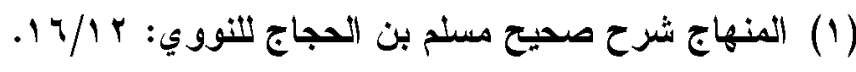

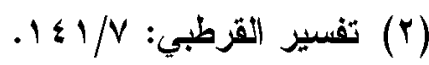

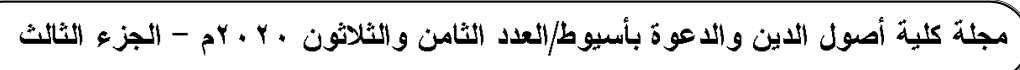


تعليماتهم، ويستطون دمائهم، وييثون هذه الأفكار العدوانية الهامة

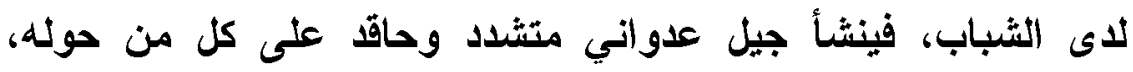

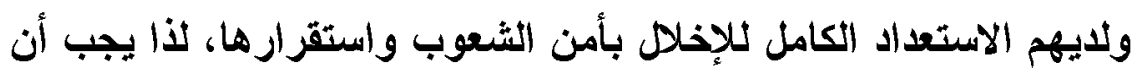
تقف الدولة بكل أجهزتها في وجه هؤلاء للقضاء على هذه الفوضى لإنى

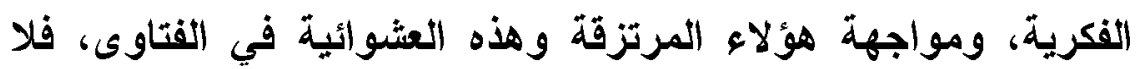

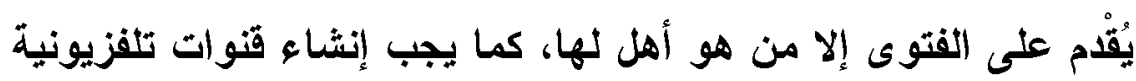

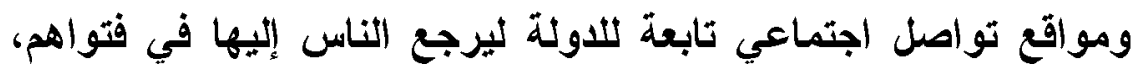

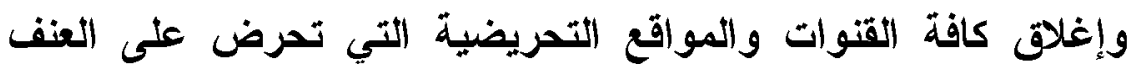

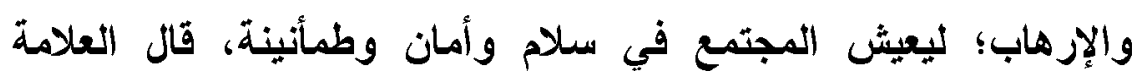

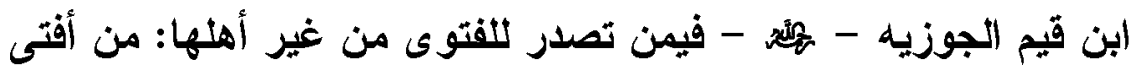
الناس وليس بأهل للفتوى فهو آثم عاص، ومن أقره من ولاة الأمور

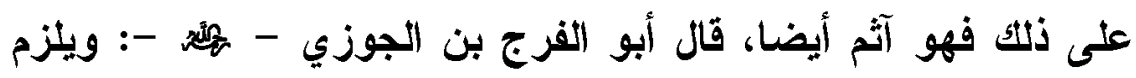

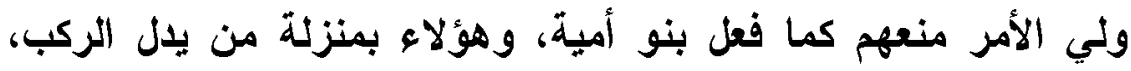

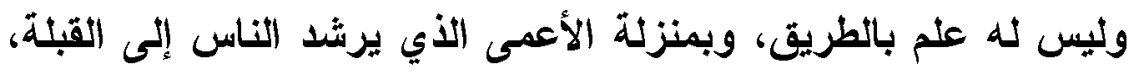

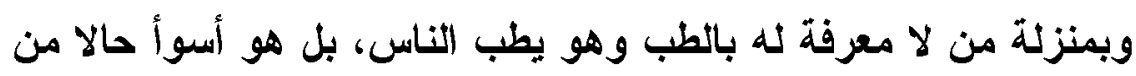

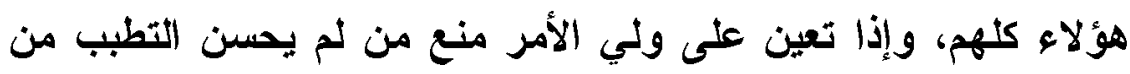

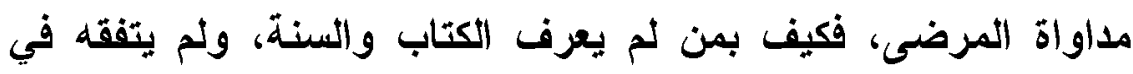
الداين؟|"). ع. تربية الأبناء تربية إسلامية صحيحة، وهذا هو دور الأسرة في مواجهة

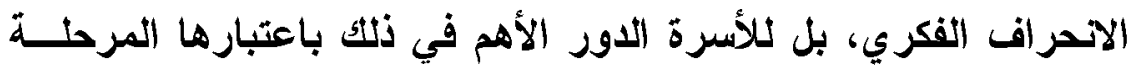

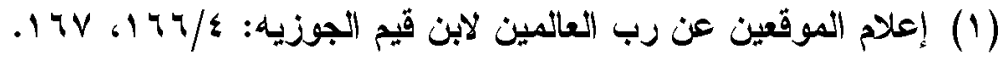

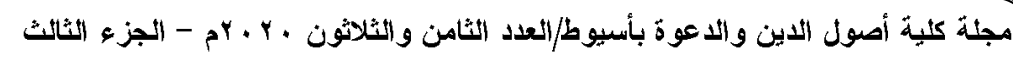


الثربوية الأولى والأساسية في حياة الإنسان، فعـن طريقهــا تتكـون الثخصية المستقبلية للفرد، ومنها يكتسـب الفــرد عاداتـهـه وتقاليــده

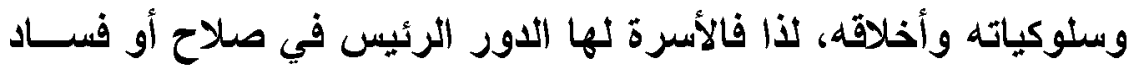

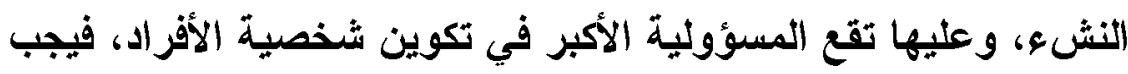

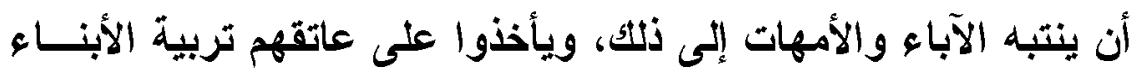
تربية إسلامية صحيحة بعيدة عن الكره والحقد والتعصب والعنف، وذلتك

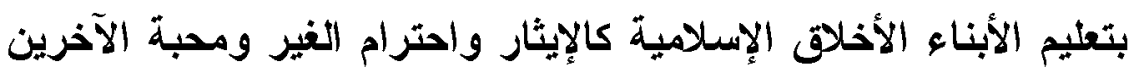

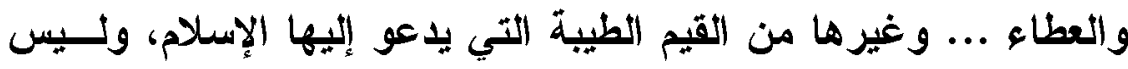

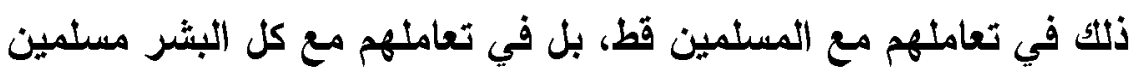

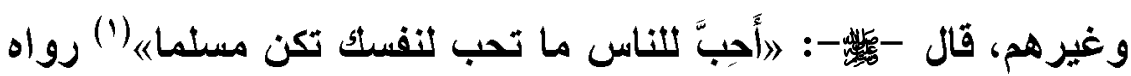
الترمذي، لم يقل للمسلمين فقط، وإنما قال للناس جميعا، كما يجب تربية

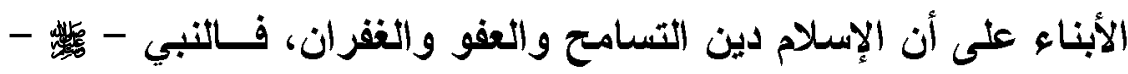

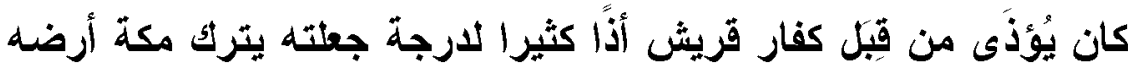

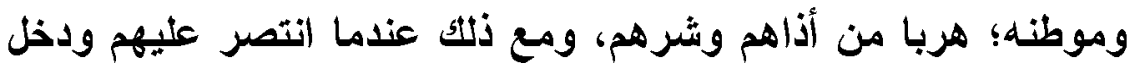

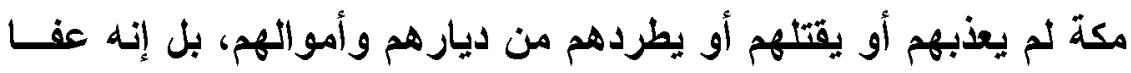

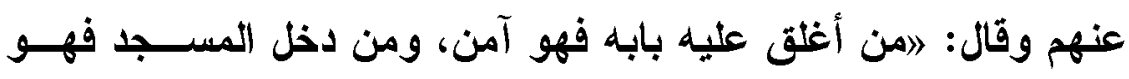

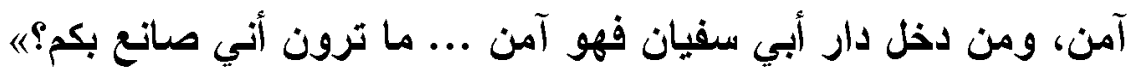

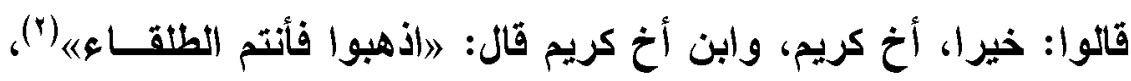

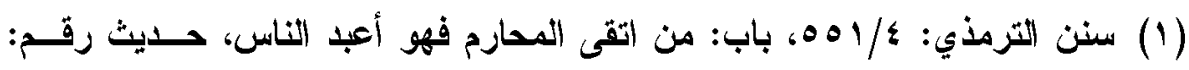

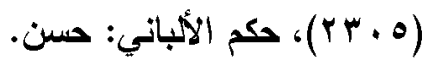

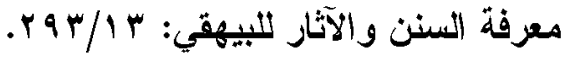

\section{$11 \%$}

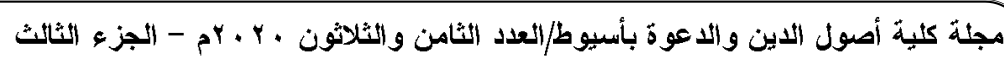


فقد سـامحهم وعفا عنهم، واحترم فكرهم، وعاشوا ســويا فـي أمسـان وسدلام تحت مظلة الإسلام.

كما يجب تربية الأبناء على أن الإسـلام دين الأمن والسـلام والرحمــة، وليس دين العنف والخوف والترهيب، فقد دعا الإسلام إلى السلم حتى مـع

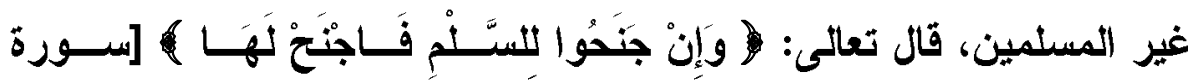
الأُفال: من الآيةة: 1 ب]، أي: وإن مالوا إلى مسالمتثك ومتاركتثك الحرب، إما بالاخول في الإسـلام، وإما بإعطاء الجزية،، وإما بموادعة، ونحو ذلتك مسن

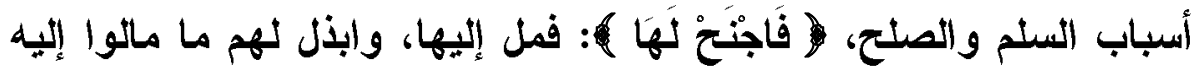

من ذلتك وسئلوكه (1).

ولمِمَا لا يكون الإسدلام دين السـلام والأمن وتحيته في الانبا هي السدلام، وفي الآخرة جعل الله تعالى تحية أهل الجنة أيضــا الســلام، قـال تعـالى:

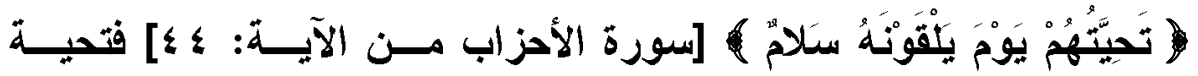

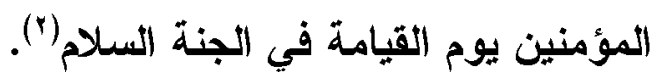

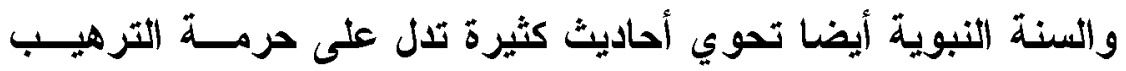
والترويع والتخويف حتى ولو على سبيل المزاح أو الإشسارة أو النظر، فعن

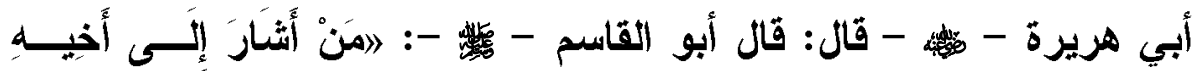

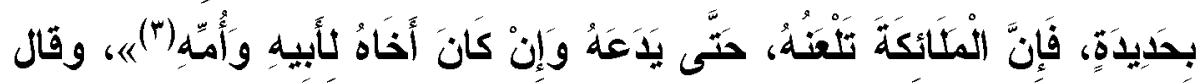

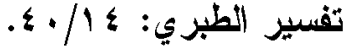

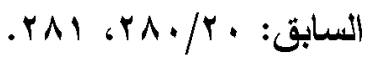

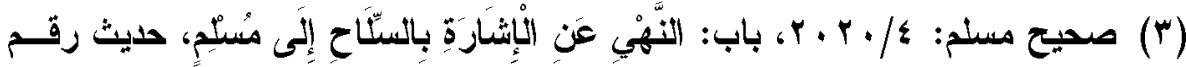

$$
.(r+1 Y / 1 \text { (ro) }
$$




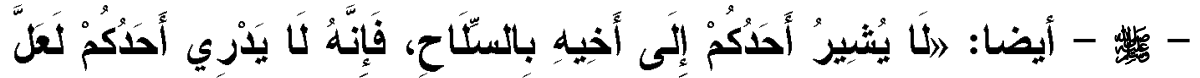

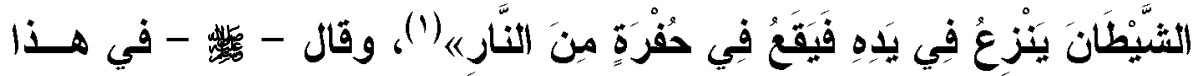

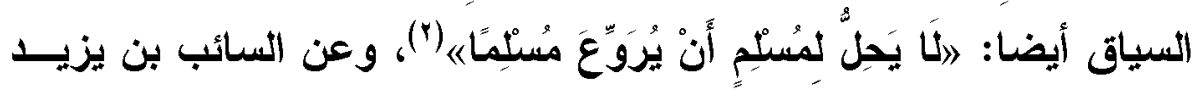
-

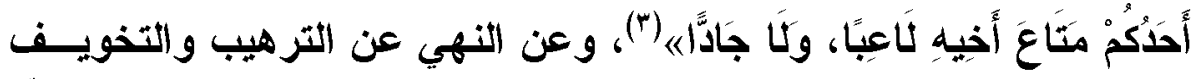

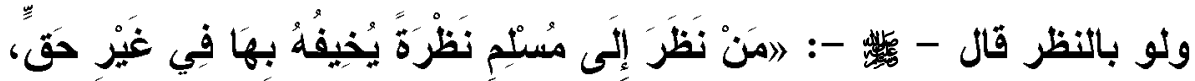

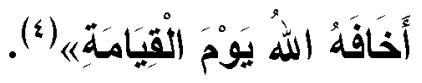

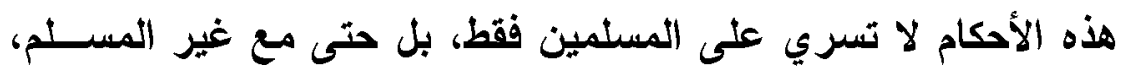

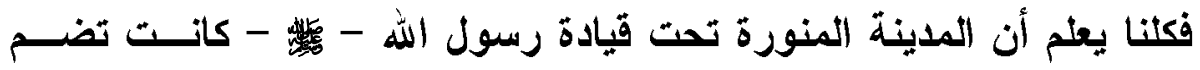

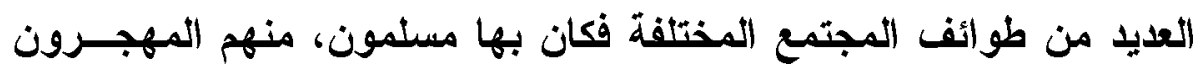

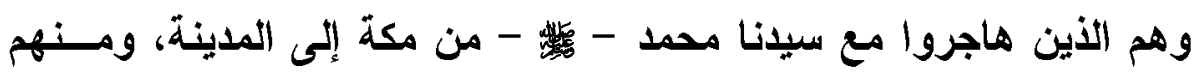

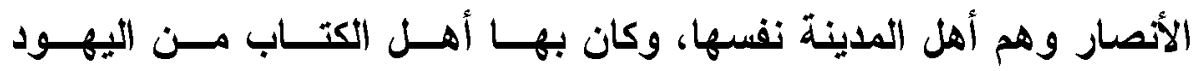

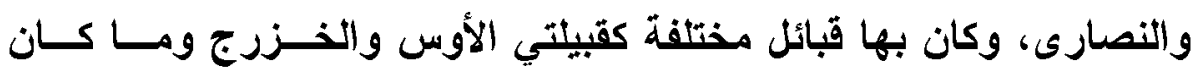

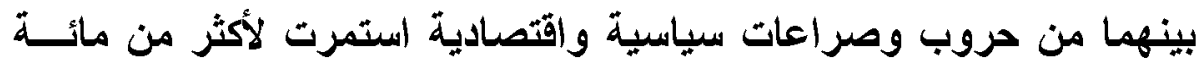

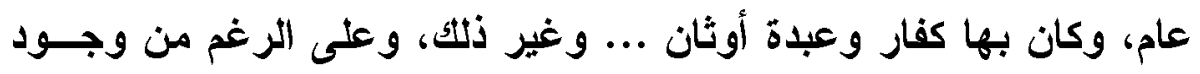

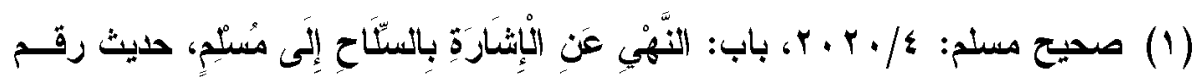

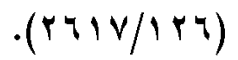

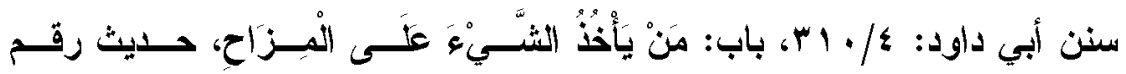

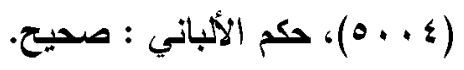

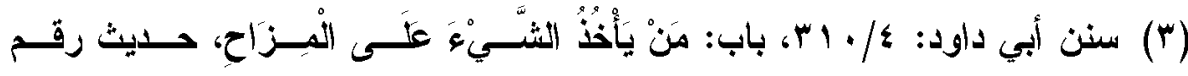

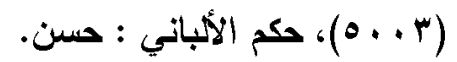

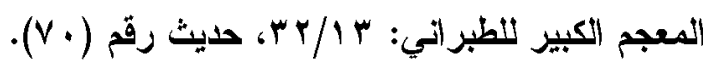

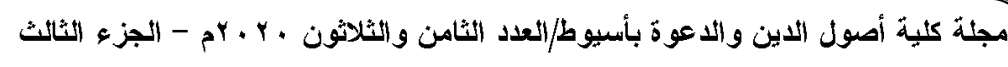


كل هذه الطوائف على اختلاف دياناتهم وهويتهم وعاداتهم وطباعهم، فة ــــ عاث الجميع تحت مظلة الإسدلام في سلام وأمان، دون تخويف أو ترهيب، وضربت المدينة المنورة في ذلك الموقت أروع الأمثئة في تطبيت الأخــلاق

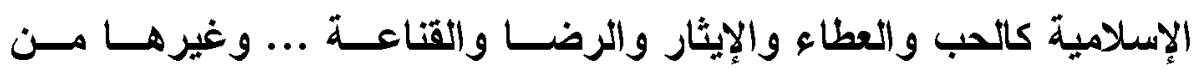

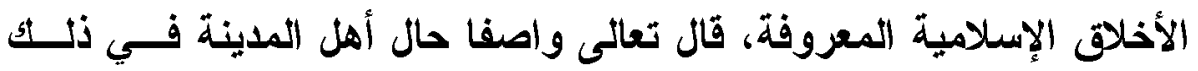

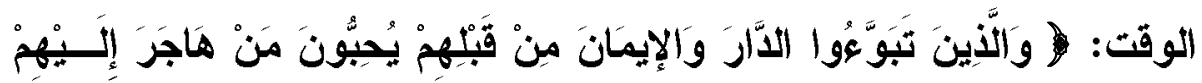

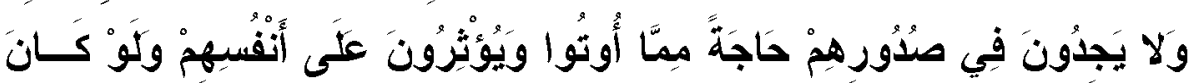

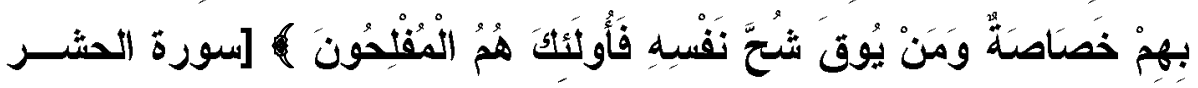
آية: 9]، جاء في تفسير الطبري: بصف الله تعالى الأنصار الأين تبــوّعُوا

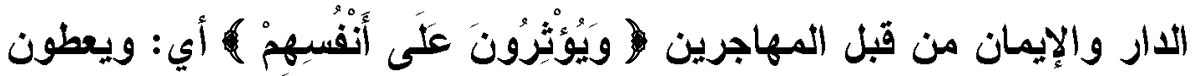

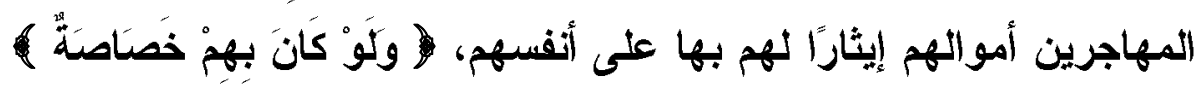
أي : وثو كان بهم حاجة وفاقة إلى ما آثزوا به من أموالهم عثى أنفسـهم،

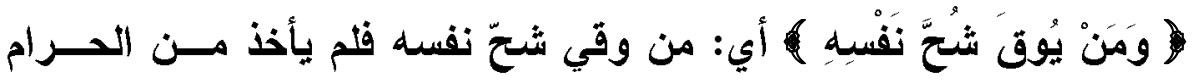

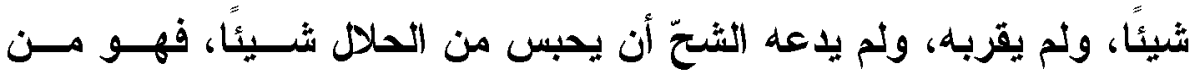
المقلحين (') أمبين هذا هو الإسلام الوسطيّ، وهذه هي الأخلاق الإسدلامية البعيدة كل البعد عن الاتتقام والغل والحقد والعدوان، فيجب تربية النشء على هذه الأخلاق

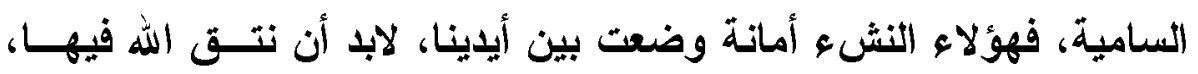
لأنتا كلنا مسؤوثون أمام الله تعالمى عن هذه الأمانة، وقا نبه رسولنا الكريم -

$$
\text { تفسير الطبري: TAV - r }
$$


الأي على الناس راع، ومسئول عن رعيته، والرجل راع على أهل بيتــه،

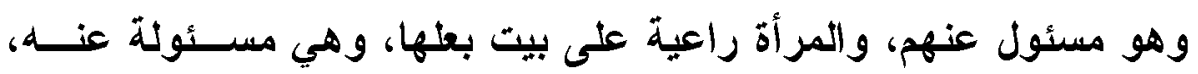
والعبد راع على مال سيده، وهو مسئول عنه، ألا فكلكم راع، وكلكم مسئول

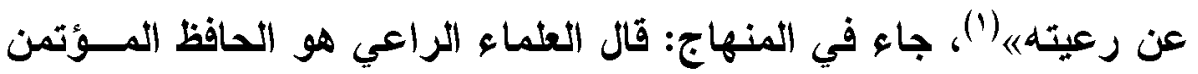

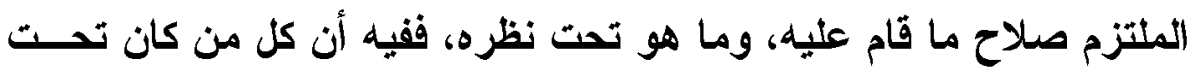
نظره شيء فهو مطالب بالتعل فيه، والقيام بمصالحه فـي دينــه ودنيــاه

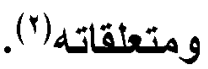

فيجب تربية الأبناء على ما بحفظ لهم دينهم ودنياهم، وتعليمهم تعاليم

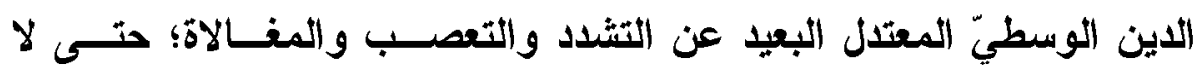
يكونوا فريسة سهلة في بـ أصحاب الأقكار الههامة بشكلونهم كيفما شاعوا.

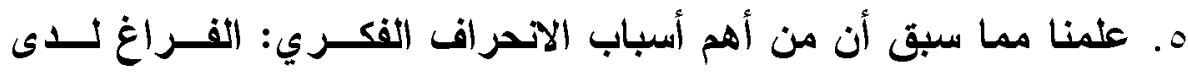
الشباب، - وكما قلنا سابقا - أن الفراغ لابى الثباب هو مكمن الخطر،

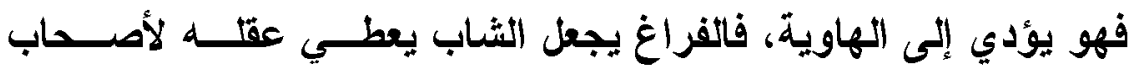

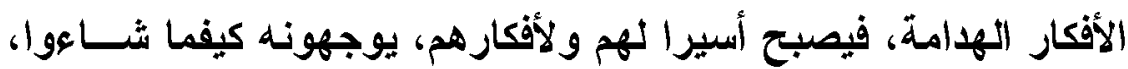
فلابد من إثغال وقت الشباب بما هو نافع ومفيد، وذلت عـن طريستق انثاء المشروعات وتثغيل الثشباب، وإنثاء التوادي والمنتديات، وعمل ندوات ومحاضرات وورش عمل؛ ثشخل وقت فراغهم؛ وتعريفهم وسطية الإسلام واعتداله، وتوضيح مساوئ التثدد والغلو؛ حتى لا يقعوا فريسة

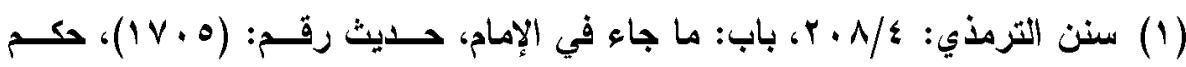
الألباني: صحيح.

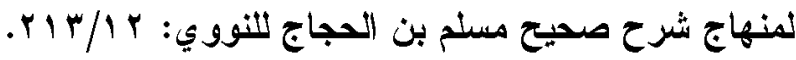




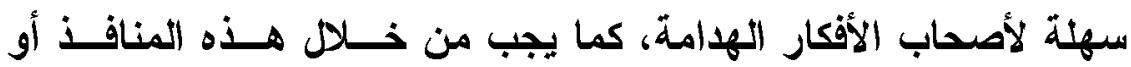
المشروعات تعريف الثباب خطورة الاتحر اف الفكري والتحذير منــه، وزرع روح الاتتماء وحب الوطن بلاخلهم، وجعهم في حالة اسـتعداد تام لصد أي غزو خارجي فكري كان أم غيره، وتعويدهم علــى تحمـل

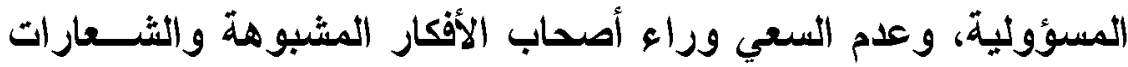
البراقة الزائفة، وإن أظهر أهلها الخير والصلاح؛ لأن هؤلاء لا يريدون إلا تدمير البلاد، وهم يعون تماما أن تدمير أي بلا يتم عن طريق تدمير فكر شبابها، فيقتحمون عالمهم وهم يرتدون ثوب الصدلاح، مما يســـل عليهم مهمة جذب الثباب إليهم، لذا يجب ألا نترك عقول شبابنا تتـأثر بهذه الفئة المغرضة الضايلة، ويجب توعيتهم بهــــا الخطــر الفكـري، والعمل دوما على صون أفكارهم من الأذى؛ لأن الحروب الآن لم تصبح حروبا عسكرية فقط، لكن هناك حروبا فكرية وحروبا نفسية وحروبــا معنوية، هذه الحروب أثثد خطرا على المجتمع من الحروب العسكرية، فعلى الشتباب أن يعي هذا، ويعي أننا نعيش في عصدر تعـددت فيـهـ التحديات الفكرية والعقدية، وأصبح الفزو الفكري أثثد خطرا من الفزو العسكري، فعلى الثشباب أن يحصنوا فكرهم ويحتاطو المـا يتثة فــوه مــن معلومات؛ خثية أن تؤثر بالسلب على أفكـار هم، فيصــبحون أســرى لأصحاب الأفكار الهـامة، حفظ الله شبابنا وبلادنا.

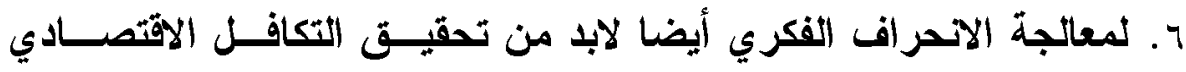
والاجتماعي في المجتمع، فـالفقر والبطالــة والظــروف الاقتصــادية

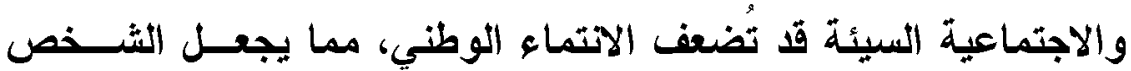


يبحث عن مصدر آخر لتحسين ظروفه المعيثية السيئة، فينساق وراء هؤلاء المرتزقة الأين بستخلون هذه الظروف ويبدعون فـي تخريسب

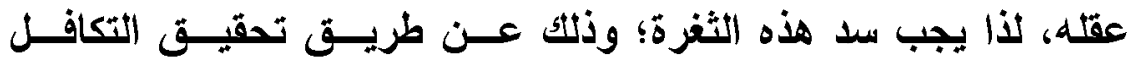
الاقتصادي بين أبناء المجتمع، ومحاولة القضاء علــى الفقــر، وفــي الحقيقة إن القضاء على الفقر والظروف الاقتصادية والاجتماعية السيئة لا يتأتى إلا باتباع تعاليم الإسـلام، فقد نص الترآن الكريم على ضــرورة

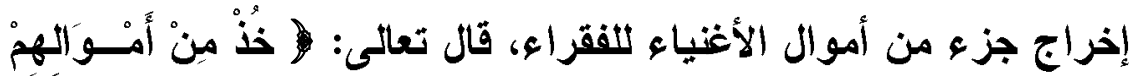

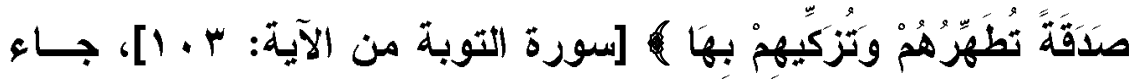
في التفسير الوسيط للزحيلي: قال جماعة من الفقهاء: المسراد بهـــه الآية: الزكاة المفروضة، فيكون الضمبر عثى هذا الرأي شامـلا جميـع التناس ...، والمعنى: خذ أيها التبي ومن بعدك من الحكام مــن أمــوال هؤلاء التائبين وغير هم صدقة مقدرة بمقدار معين، تطهــرهم مــن داء البخل والطمع والأنوب، وتزكي أنفسهم وتطهرها بهــا، وتنمــي بهــا

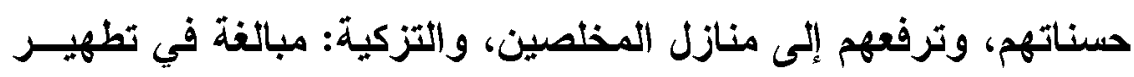
المال وزيادة فيه، أو بمعنى الإنماء والبركة في المال، أي إن الله تعالى يجعل النقصان الحاصل بسبب إخراج قدر الزكاة سببا للإنماء|(').

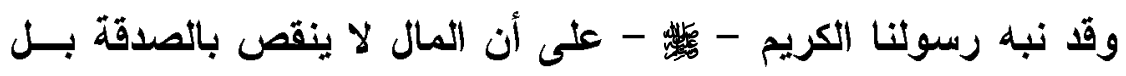

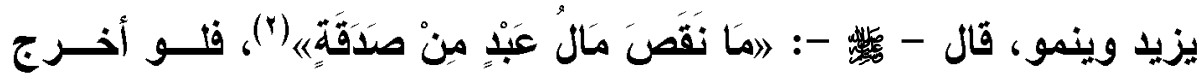

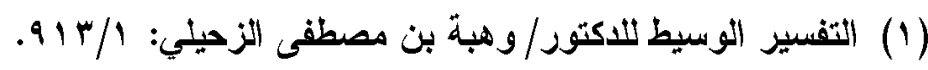

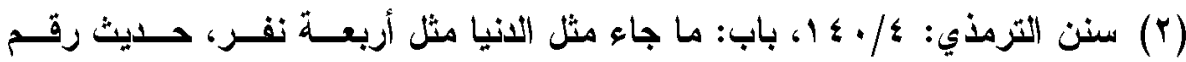

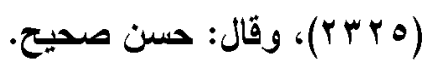


الأغنياء زكاة أموالهم بحق لحدث التكافل الاقتصادي بين أبنــاء المجتمـع الواحد، ولقُضِيَ على الفقر، وتحسنت أحوال الناس المعيشية، لكن ما يحدث للأسف عكس ذلتك، فقد أصبحنا في مجتمع طغت عليه النظريات المادية بكل

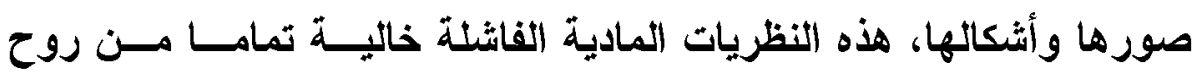
التكافل والمودة، فكل ما يهمها الفرد فقط دون التفكير في الجماعة، فخلقت نوع من الأنانية وحب الذات، وكان من نتائجهــا أن زادث الفجــوة بـين

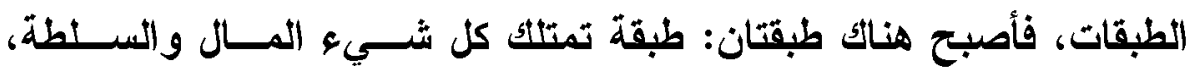
وطبقة لا تمتلك شيء، فأصبح الغني يزداد غنا، وكلما ازداد غِنا كلما ازداد بخلًا، وأصبح الفقير يزداد فقرا، وكثما ازداد فقرا كلما ازداد حقدا وغلا على بلى كل من حوله، هذه الأثثياء خلقت جيلا معقدا ساخطا على أوضاع مجتمعه، ناقما عثلى كل من حوله، وقل بستغل أصحاب النفوس الضعيفة هذه الثغرة، ويقومون باستقطاب هؤلاء الثباب مستفلين ما يمرون بــه مــن ظـــروف

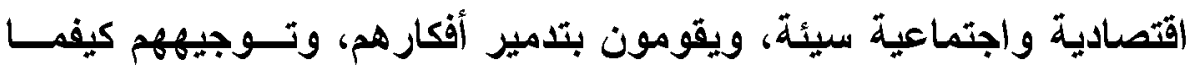
شاءوا، وهذا خطر كبيز يلمر الثُعوب والمجتمعات، وقا نبه القرآن الكريم إلى عدم جعل الأموال في يد الأغنياء فقط دون الفقراء فقال جـلـ شــأنه:

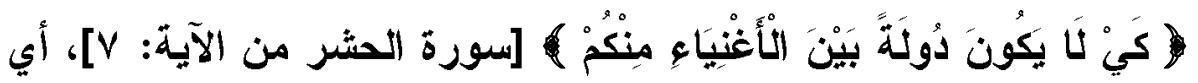
كي لا يكون الفيء الذي أفاء الله على رسوله من أهل القرى دولية ينتفع به الأغنياء دون الفقراع(1)، وفي ذلتك من الفساد والضرر ما لا يعلمــهـ إلا الله تعالى، فلو اتبعنا ما أمر الله به، وأحسنا تطبيق النظام الإسـلاهي في تـــاول المال وفي طريقة كسبه وإنفاقه، لحدث التكافل الاقتصادي والاجتماعي الأي 
نبحث عنه، ولزالت الفوارق بين الطبقات، واتتهى الفقر، وبذلك نكون قـــ قمنا بسد ثغرة هامة أمسام أصحاب الأفكار المنحرفة، فلا يستطيعون السبطرة على عقول شبابنا، بل إن هذا يقوي روح الاتتماء بـين الثــباب فيصــبح

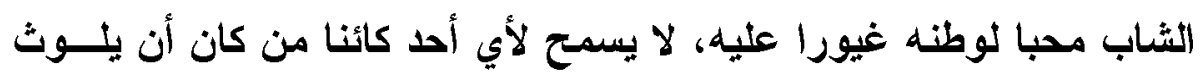
أقكاره أو يثوهها، ويقف في وجه كل من تسول له نفسه المساس بــأمن

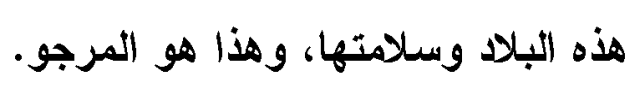

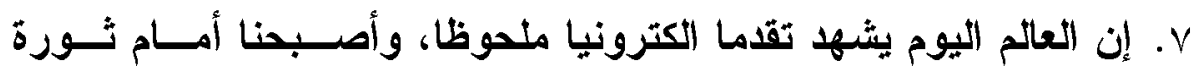

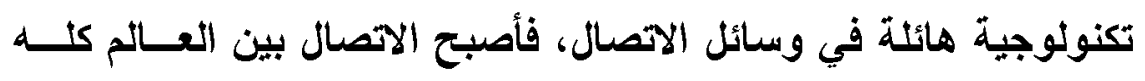
سهلا ويسيرا، وكما يقول العلماء: أصبح العالم كالقرية الصغيرة بسبب التقدم الغير مسبوق في وسائل الاتصال، وهــــا مـــا يســيه علمــاء

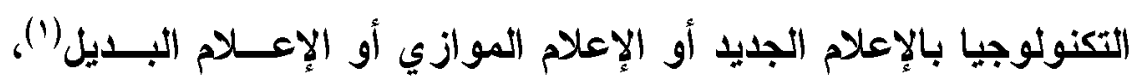
وهو يختلف عن الإعلام التقليدي في أنه سريع الاتتثــار، ولا يمكـن السيطرة عليه إذ ليس له ضابط أو رابط، هذا الإعلام متاح في أي وقت وأي مكان ولأي شخص، ويمكن من خلاله نشر شـــايُعات وأكاذيـبـ لا صحة لها وتنتثر بسرعة البرق انتشار النار في الهثيم.

(1) الإعلام الجليد Mew Media أو الإعلام الرقمي Media Digital هو مصسـلح

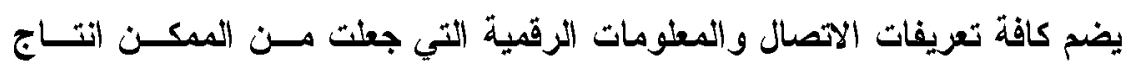

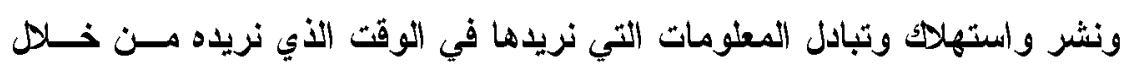

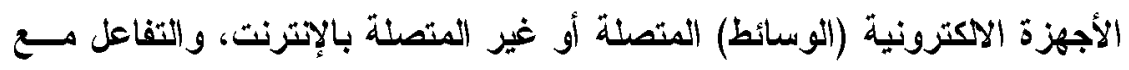

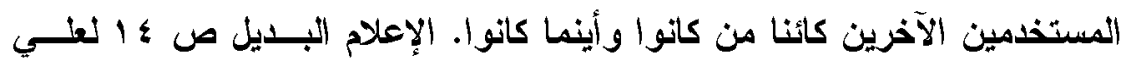

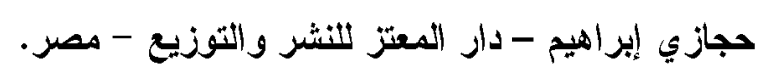

\section{9}

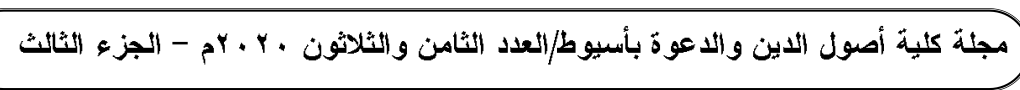


كل هذا الكم من المعلومات الخاطئة والأكاذيب التي نطالعها يوميا على عثى مواقع التواصل الاجتماعي تحدث بلبلة وفوضى في المجتمعات، وكثيرا مـــا

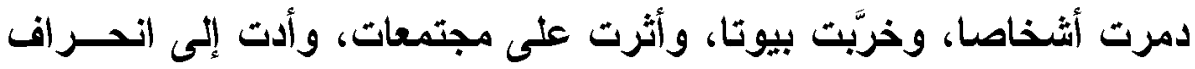
شعوبها، دون أن يكون هناك حساب أو عقاب لناشــري هــــه المعلومـــات الخاطئة والثائعات الكاذبة ... هذا النوع من الإعلام غير المنضبط الذي لا يصعب السيطرة عليه، أخطر على المجتمع من أي أخطار أخرى، فهناكك من

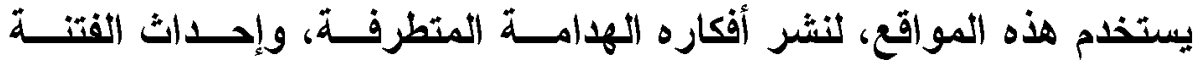
والفوضى بين فئات المجتمع، وهذا يفرض عثلينا عبئا كبيرا تجاه اســتخدام

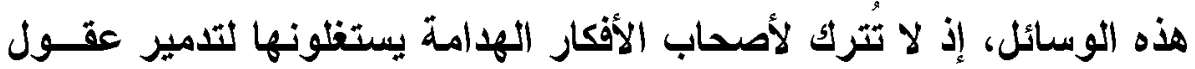
أبنائنا، فنحن بحاجة إلى تقتين وتنظيم هذا الإعلام الموازي، حيث إن تقتينه وتتظيمه ليس صعبا أو مستحيلا، خاصة لأهل الاختصاص من العلماء فــي هذا المجال، فيجب عليهم الإفادة من هذه الوسائل واستغلالها في معالجــة

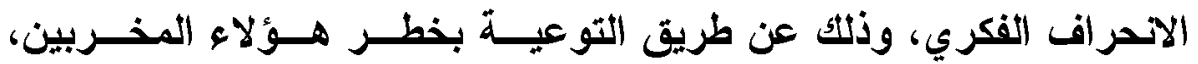
والتحذير منهم وممن يتبعهم، ونشر مبادئ الاين الوسطيّ الحنيف البعيـــ عن التثدد والتعصب والمغالاة، خاصة وأن هذه الوسائل أثتبت فعاليتها في التأثير على المتثلي بثكل كبيز، فيجب التعامل معها بحذر شديا، ومحاولة حجب أو إزالة كل ما يحاول أن يدمر عقول شبابنا، أو ينشر الأخبار الكاذبة ليُحدث الفوضى والبيلبة في البلاد. ^. تعزيز مبلأ الاتتماء وحب الوطن لاى الشباب، فالاتتماء يجعل الثخص

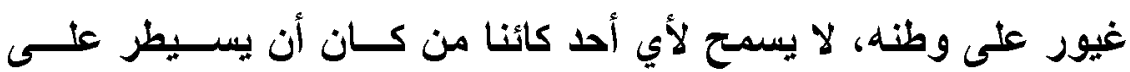
أقكاره أو يوجهها، والاتتماء وحب الوطن مطلب شرعي، فقد أمسر الله 
تعالى المؤمنين بالتمسك والوحدة وعدم التفرقة، لأن في الوحدة قــوة

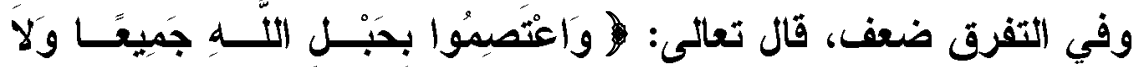

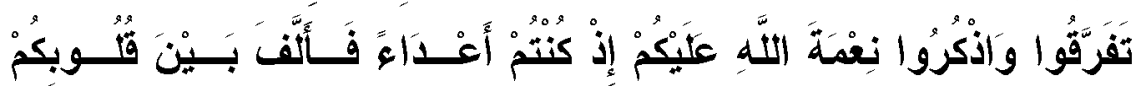

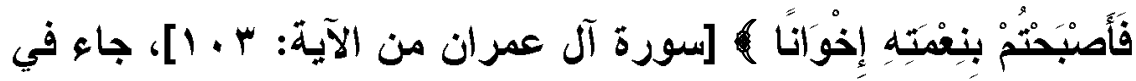

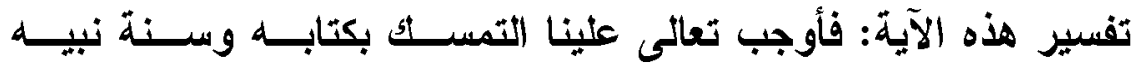
والرجوع إليهما عند الاختلاف، وأمرنا بالاجتماع على الاعتصام بالكتاب والسنة اعتقادا وعملا، وذلك سبب اتفاق الكثمة وانتظام الثتات الـــي يتم بـه مصالح الانيا والاين، والسـلامة من الاختلاف، وأمر بالاجتمــاع

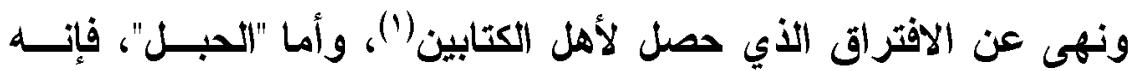
السبب الأي يوصل بـه إلى البُغية والحاجة، ولذلكت سمي الأمان "حـبلا"،

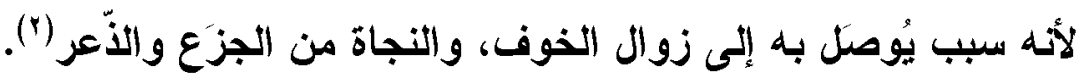

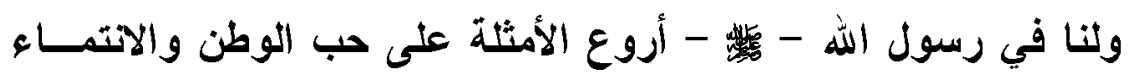
إليه، فكلنا يعلم أذى أهل مكة له، وإجباره على الخروج منها، وعلى الرغم

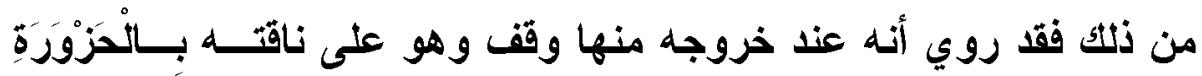

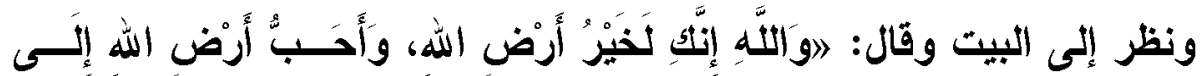

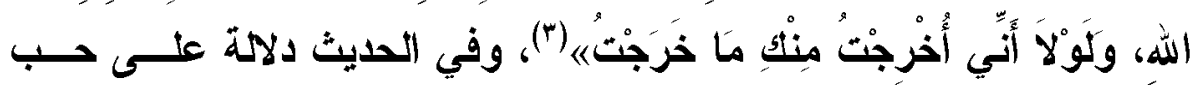
الوطن والاتتماء إليه مهما قسى أهله.

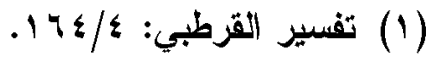

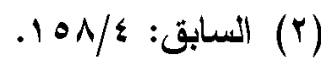

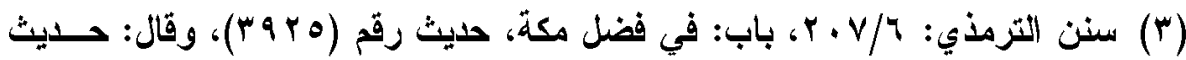
حسن صحيح غريب، الحزورة: موضع بمكة. 


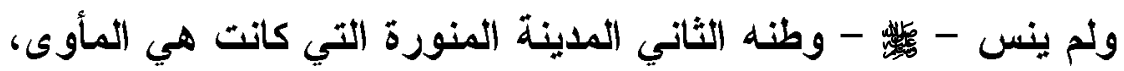

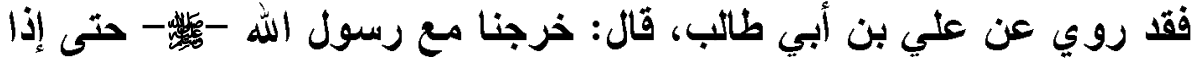

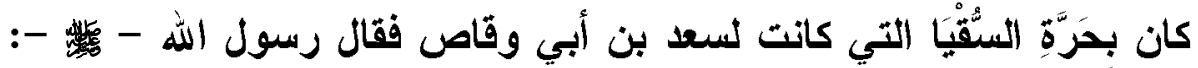

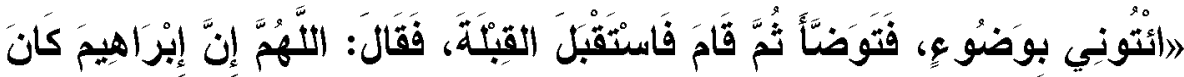

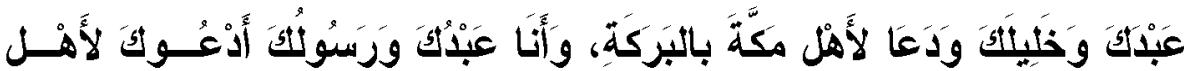

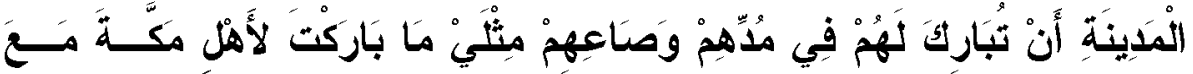

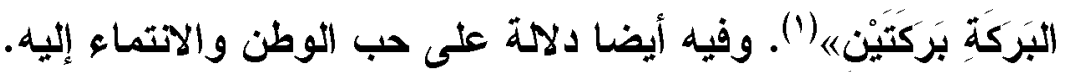
كذلتك من أسباب تعزيز مبدأ الاتتماء وحب الوطن: طاعة ولي الأمر في

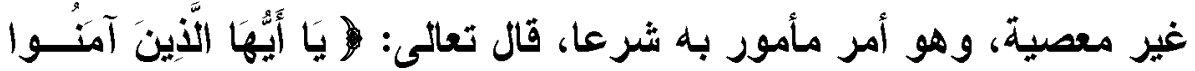

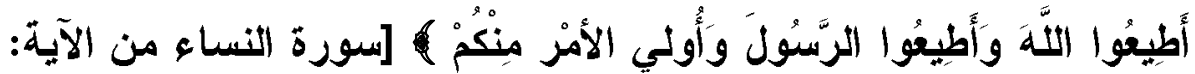

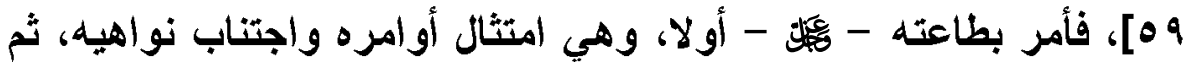

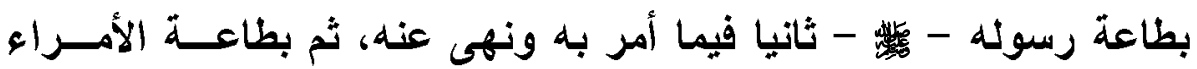

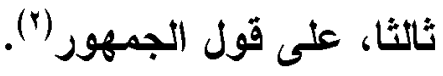
فمن المعروف أن طاعة ولي الأمر في غير معصية الله دليل على حب ألى الوطن والانتماء إليه، وتفويث الفرصة عثى أعداء الإسـلام من إيقاع الفرقة بين صفوف المسلمين. لذا يجب على كل الجهات المعنية في كل البلاد أن ينموا هذا الثـــور لاى أبناء المجتمع، حتى بصبح المجتمع كله كالنسيج الواحد أو كالبنبـان

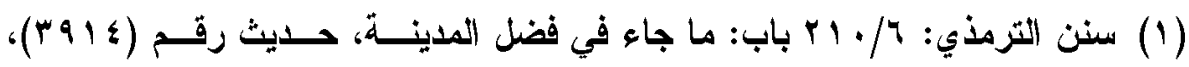

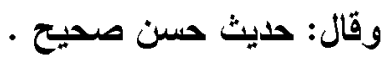

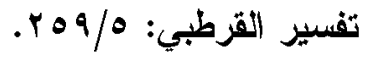

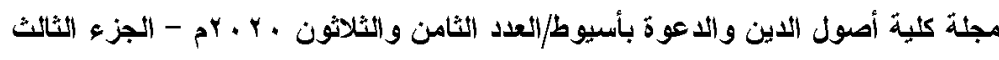


المرصوص يقوي بعضه بعضا .

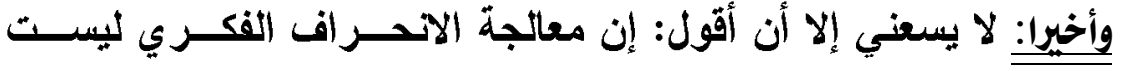

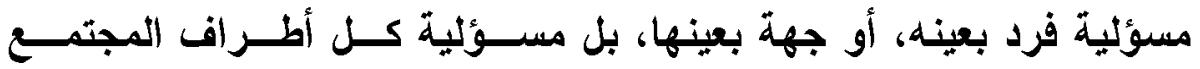

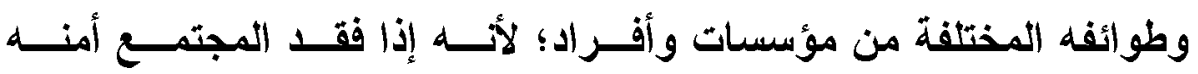
وسيطرت عليه الفوضى سيؤثز ذلتك سلبا على مؤسساته، وإذا أصاب الخلل

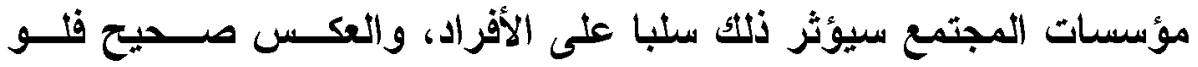
أصاب الأفراد الاتحر اف الفكري فسوف يؤثر ذلتك على مؤسسات المجتمــع بأكمله، ويكون من نتيجة ذلتك انتشار الفوضى والخــوف وعـــم الأمـــان، وتتحول البلاد الهادئة المطمئنة إلى غابات تحوي حيوانات مفترسة شرسة، تنهش كل ما تراه أمامها من الأخضر والبابس، وحتى لا تحدث هذه الكارثة - والعياذ بالله - علينا جميعا كأفراد ومؤسسات الوقوف في وجه كل مسن يحاول أن يدمر العقول، ويسيطر عليها ويوجهها كيفما شاء، ولا يتأتى ذلك إلا باتحاد الجميع يدا واحدة، ويعلم كل منا دوره، ولا يجوز التقليل من شأن أحد، فكل منا له دوره المؤثر في هذه المعركة التي يجب أن نتتصر فيهــا، حتى تعيش المجتمعات في سلام وأمان وطمأنينة، وذلك على النحو التالي: المجتمـع اللدولي: عليه أن ينبذ الإرهاب الفكري وجميع أنواع الإرهـاب لهاب

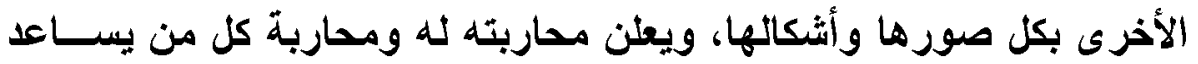
هذه العصابات المجرمة التي تهدف إلى تدمير الثُعوب وخر ابها. قادة البلاد: عليهم مسؤلية عظيمة في مواجهة هذا الانحراف، فهُم

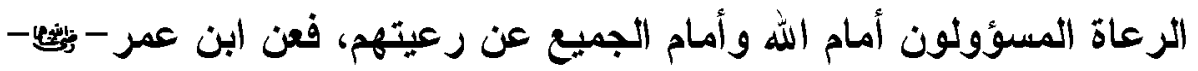

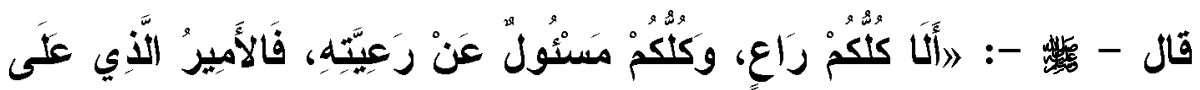




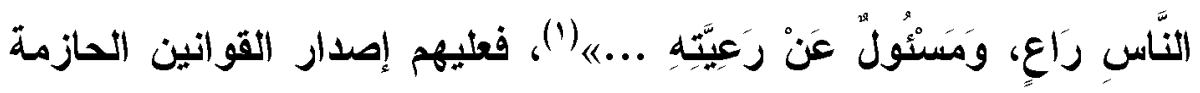
الصارمة ضد كل من يحاول زعزعة أمن واستقرار البلاد، وعثيهم أن بنهوا أي خلافات طائفية داخل المجتمعات، ويجعلوا طو ائف المجتمع كالجسد الو احد الأي إذا الشتكى منه عضو تداعى له سائر الجسد بالحمى، فيعملوا على اجتماع الصفوف وتوحيد الكلمة؛ حتى يستطيعوا أن يقفوا في وجه الأعداء ويهزمو هم بإذن الله؛ لأن في الاتحاد قوة وفي التفرق ضعف، فأبناء المجتمع أمانة في أبديهم، عليهم حمايتهم وتوجيههم وتذليل الصعاب أمامهم حتى يشعروا بالأمن والأمان داخل مجتمعاتهم، وحتى يحموا عقوثهم من الاتحر اف.

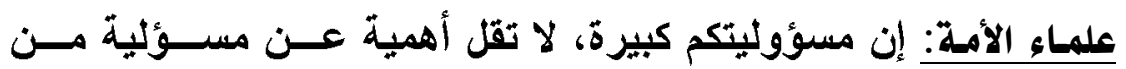
سبقكم، فعليكم مسؤلية توضيح وسطية الاين وعدم تثدده، وبيان سماحته

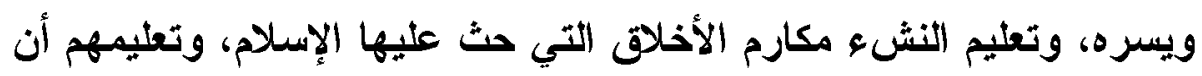
حب الوطن والانتماء إلبه واجب ديني ومطلب شرعي، وتحذيرهم من أعداء

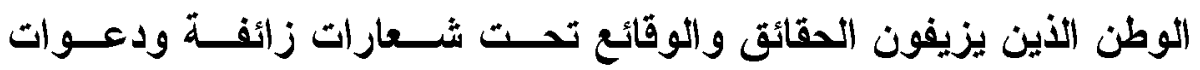
مغرضة؛ لتحقيق أهداف وضيعة لا تريد إلا تدميز المجتمعات وهدم كيانها،

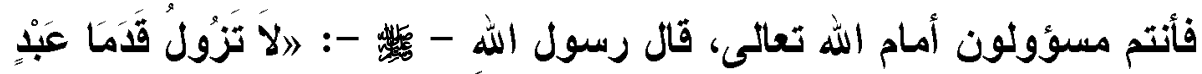

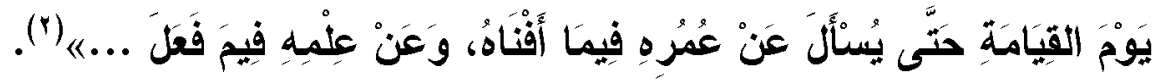

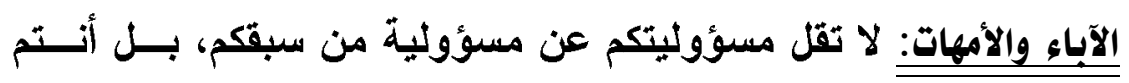

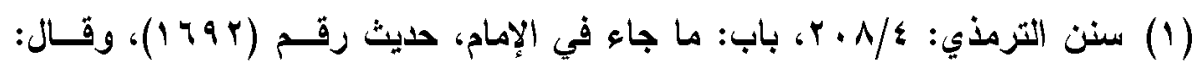
حيث حسن صحيح.

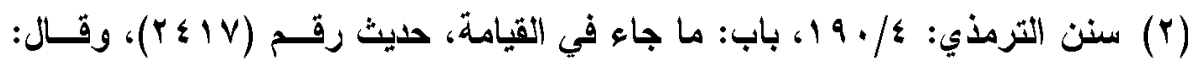
حيث حسن صحيح.

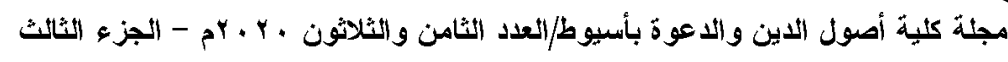




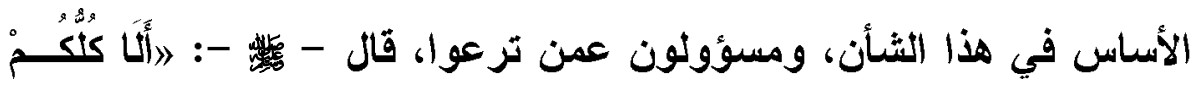

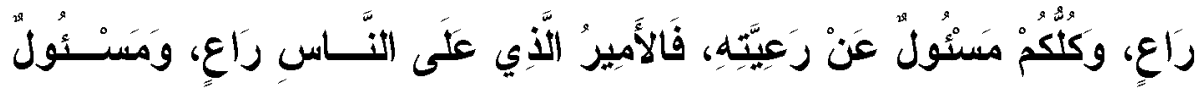

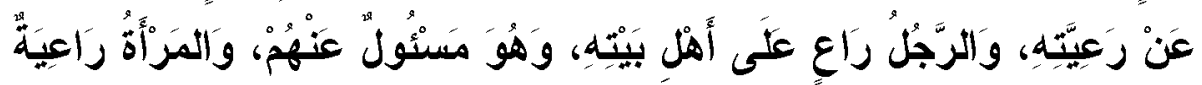

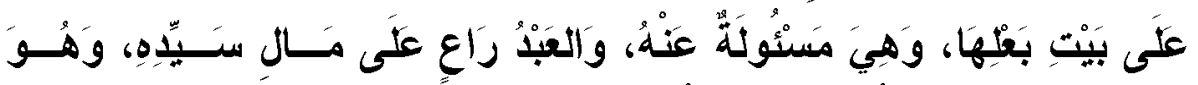

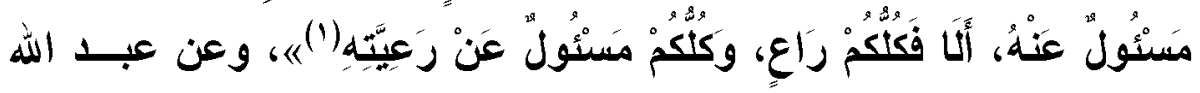

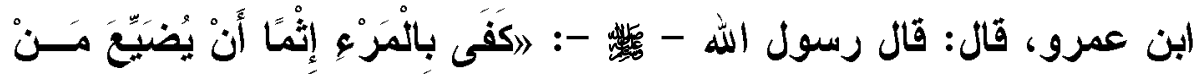

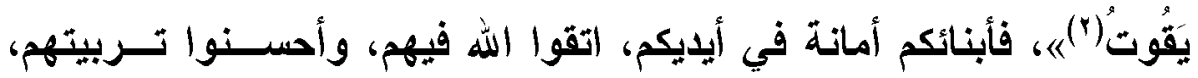
وعلموهم مبادئ دينهم الوسطي" الحنيف، وتابعوهم حتى لا ينســاقوا وراء المشككين المضللين، وحذروهم منهم، وقدموا لهم النصح والإرشاد دومسا، فكلنا مسؤولون عمن نرعاهم. شباب الوطن: عليكم المحافظة على أوطانكم، فالوطن أمانة في أيـديكم، بكم ينهض، وبكم يتقدم، وبكم قا يسقط أيضا، فلا تعطوا الفرصة لإسقاطه،

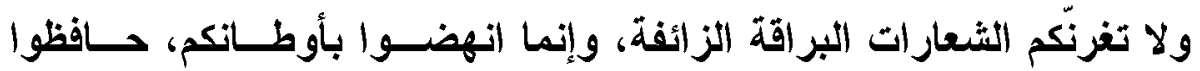
عليها، واتقنوا عملكم، واشغلوا أوقات فراغكم بما يفيدكم ويفيد أوطــانكم،

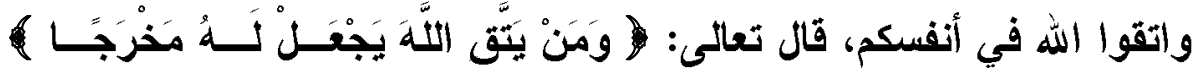

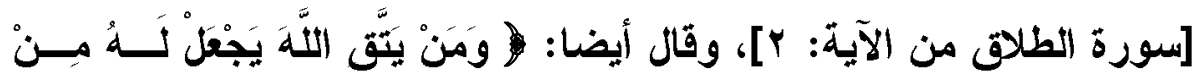

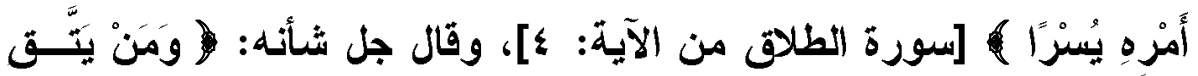

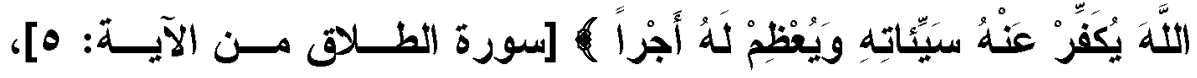

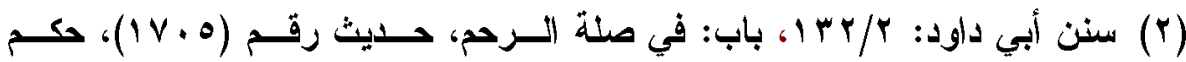

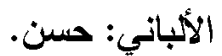

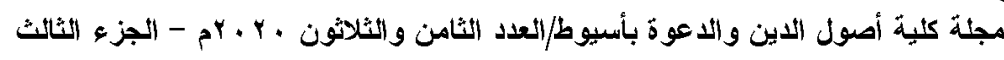




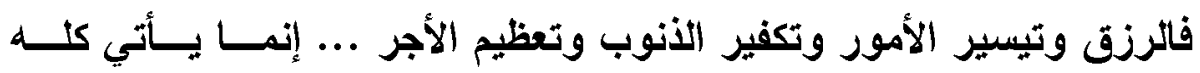
بتقوى الله - كئل -، حفظم الله شباب أمتنا من كل مكروه وسوء، وهداكم جميعا لما يحب ويرضى.

أصحاب المال والاقتصاد ورجسال الأعمال: إن طلب الرزق والسعي التحصيل

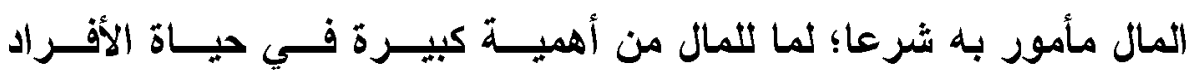
والمجتمعات، فهو وسيلة هامـة لتحقيق مقاصد دنيوية وأخروية، فقد جعله الله تعالى قواما للحياة، إذا ما روعي في كسبه وإنفاقه تقوى الله عز وجل،

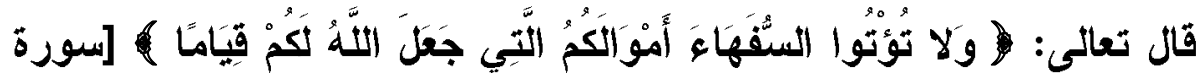

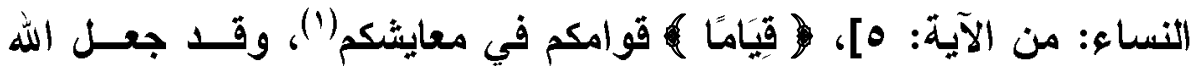

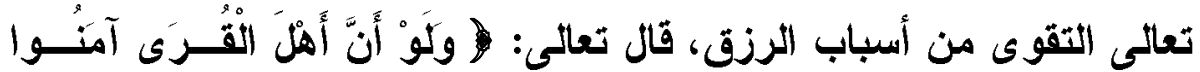

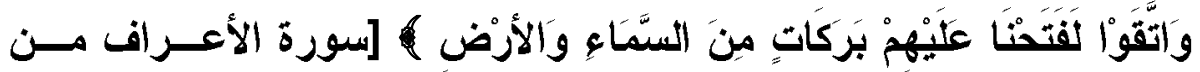

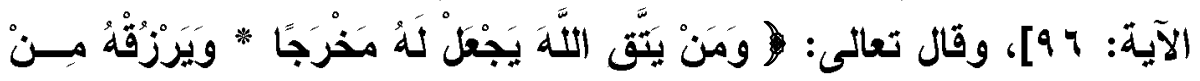

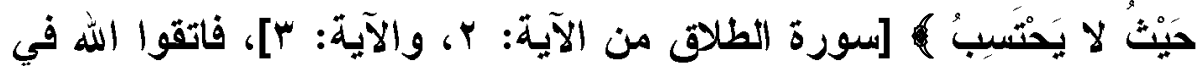
أموالكم، وابتعدوا عن الثبهات في جمعها وإنفاقها، فلا تتعاملوا بالربا، ولا تحتكروا ولا تغثتوا ولا تبيعوا المحرمات كالمخدرات وغيرهــا، وأخرجــوا زكاة أموالكم، وتصدقوا على الفقراء و المساكين، وأنفقوا في أوجه الخيـر كثيرا، واتبعوا ما أمر الله به، واتتهوا عما نهى عنه، فإنكم مسؤولون عن جمع هذا المال وعن أوجه إنفاقه، جاء في السنة الصــحيحة عـن التبـي ولهي -

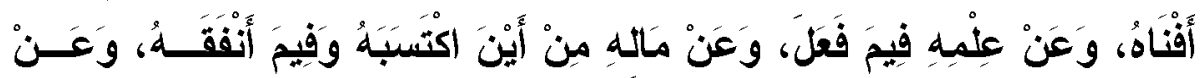

\section{$11 \leqslant 9$}

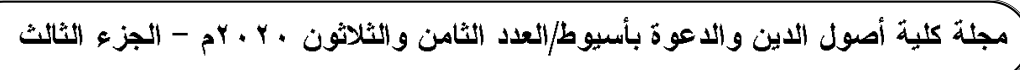




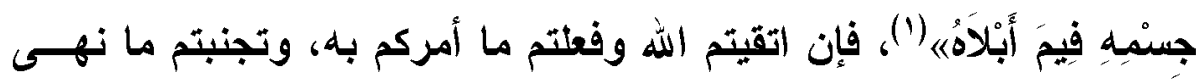
عنه، فسوف ترتقون بأوطانكم، وتسـاهمون في علو شأنها ومكانتهــا بـين الأمم، ويعيش المجتمع كله في أمن وأمان وسلام. رجال الصحافة والإعلام: إن دوركم في قضية الأمن الفكري لا يقل أهمية عن دور من سبقمم، فأنتم تملكون أدوات التأثير الفعال على أفراد المجتمع، وبذلك تملكون سدلاحا ذو حدين، حد الحق وحد الباطل، فإما أن تعتفلوه في نثر الحقائق والفضائل ومحاربة الفاسدين والمخربين والمجرمين، وهـــا الواجب والمفروض عليكم، وإما أن تشتخدموه في نشر الثشائعات والأكاذيب وتضليل الثعوب - والعياذ بالله -، وهذا لا يليث بكم فعله؛ لأُـــه محسرم

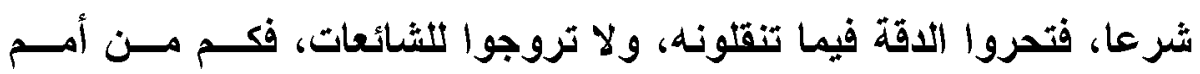
دُمِّرت بسبب الثنائعات، وكم من عظماء هلكوا بسبب الثنائعات، وكم مسن جر ائم ارتكبت بسبب الثائعات، فكلنا يعلم خطر هذه الثائعات، وما تشــببه من فوضى ودمار وزعزعة للمجتمعات، ولنا في حديث الإفك عبرة وعظة، فلولا العناية الإمهية لكادت هذه الثائعة أن تلدر كل ما تجده أمامهـــا مــن

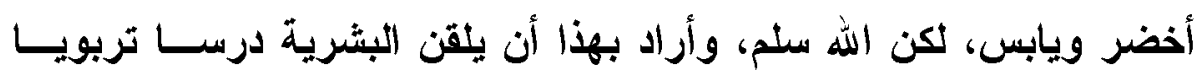

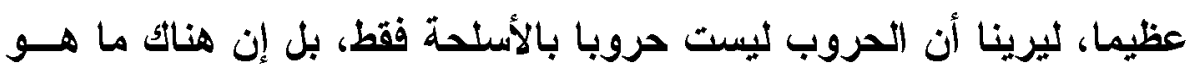

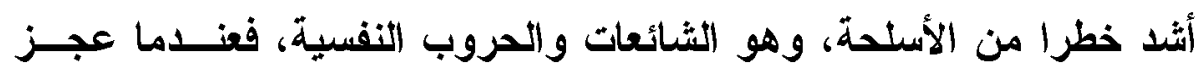
المثركون عن محاربة الإسدلام بالأسلحة، اتجهوا إلى وجهة أخرى وهي أن بعضا منهم يتظاهر بالإسـلام وهو يضمر في نفسه الكفــر، ويقتـرب مــن

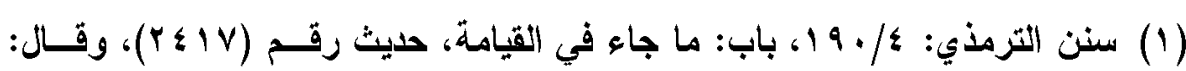
حيث حسن صحيح.

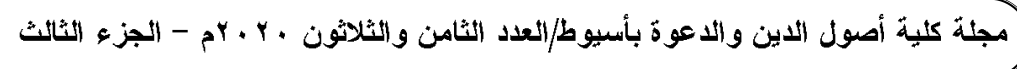


المسلمين ويتعايش معهم ويحضر صلاتهم وعباداتهم، وعندما تأتي الفرصة

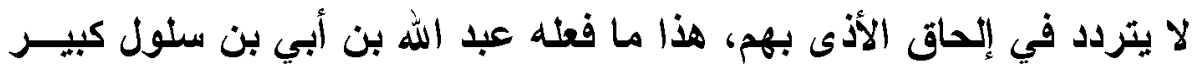

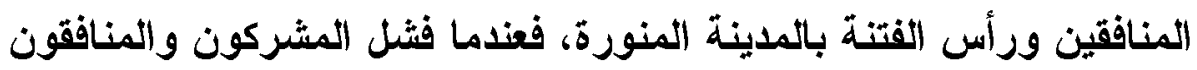

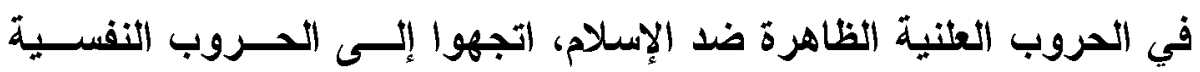

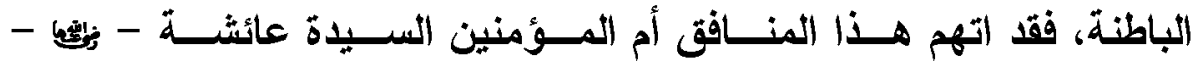

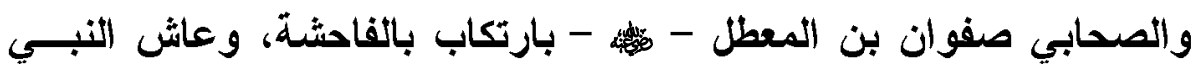
-

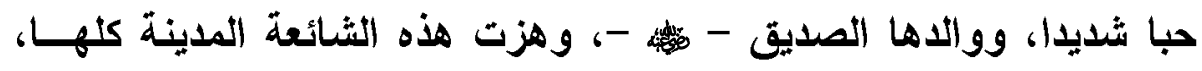

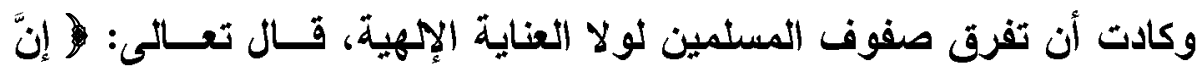

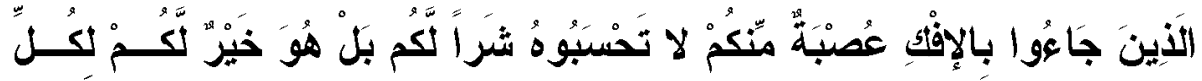

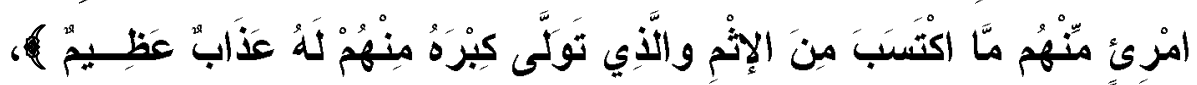

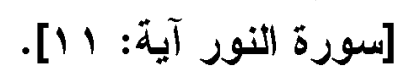

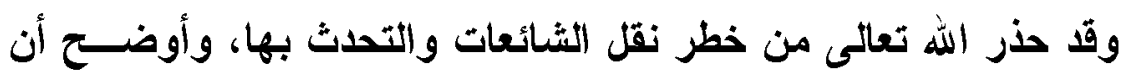

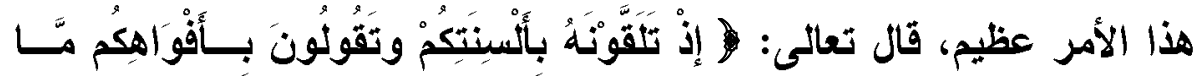

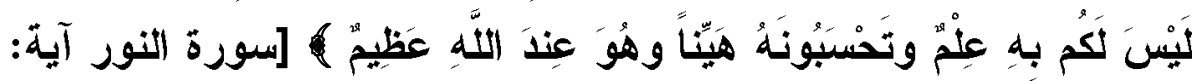

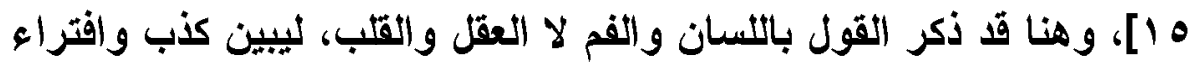

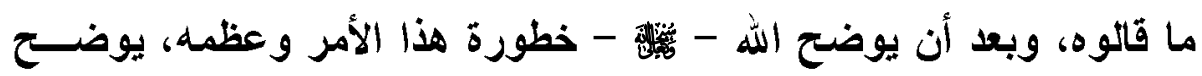

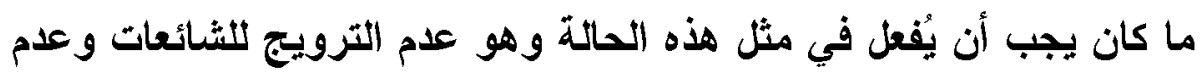

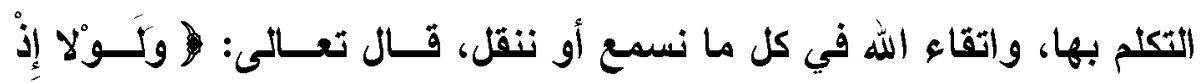

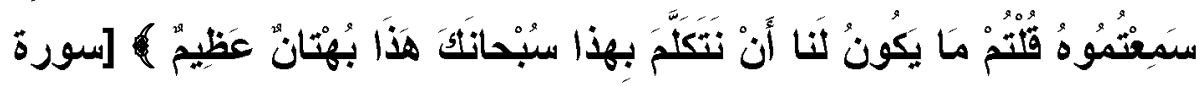

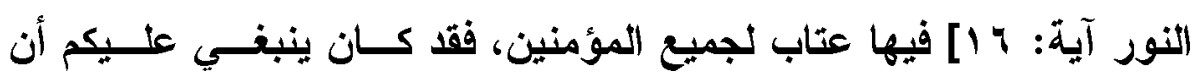

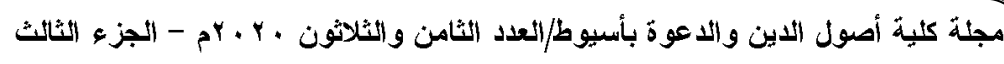


تنكروه ولا يتعاطاه بعضكم من بعض على جهة الحكاية والنقل، وأن تنزهوا الله تعالى عن أن يقع هذا من زوج نبيه - عليه الصلاة والســلام -، وأن تحكموا على هذه المقالة بأنها بهتان، وحقيقة البهتان أن يقال في الإنسان ما ليس فيه، و الفيبة أن يقال في الإنسان ما فيه(').

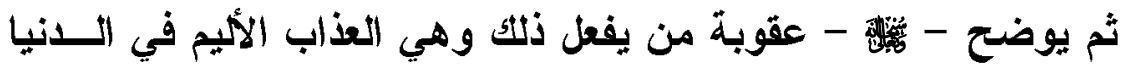

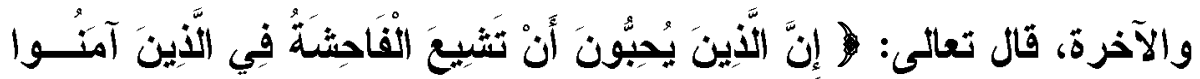

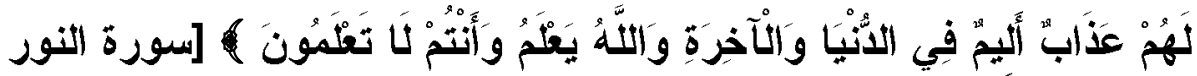
آية: وهذه الثائعة لم تكن أول شائعة في الإسلام، فالتاريخ الإسـلاهي مليء

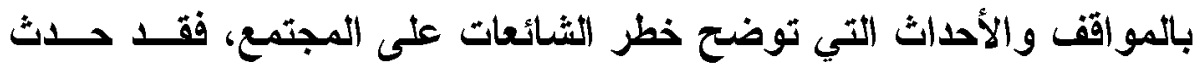

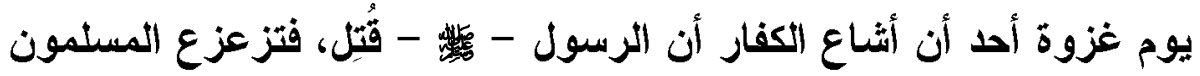

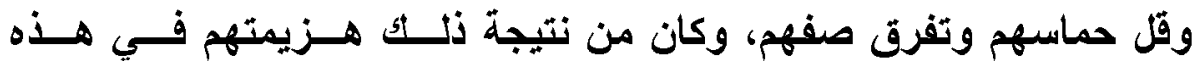

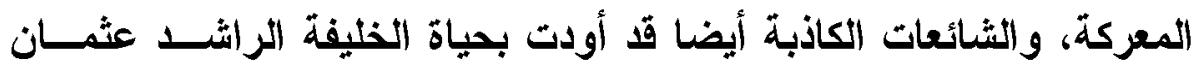

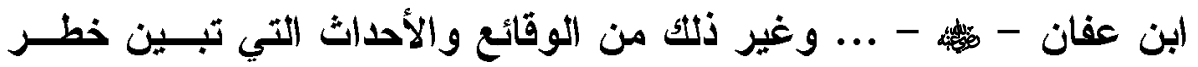
الثائعات، التي تمتلئ بها صفحات التاريخ. هذا ما تفعله الثائعات تؤدي إلى خراب المجتمعات وتدميرها، لذا على رجال الصحافة والإعلام تحري الدقة فيما ينقلوه، والتأكد من صــتهنه، وأن يجعلوا من إعلامهم وسائل دعوية للخير والحب والسلام ونشــر الفضــائل

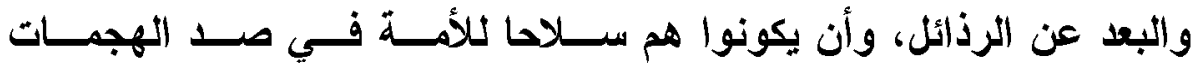
الخارجية؛ لما ثهم من تأثير كبيز على الثعوب إيجابا وسلبا.

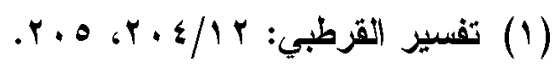




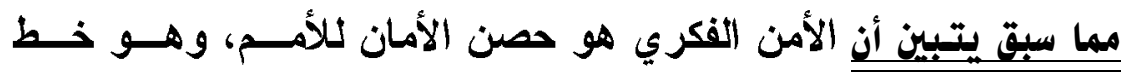
الافاع الذي إذا سقط سقطت معه البلاد - والعياذ بالله - لذا علينا مقاومـــة الاتحر اف الفكري بكل صوره وأثثكائه، كما علينا تعزيز وترسـيخ مفهــوم الأمن الفكري، وحماية عقول أبنائنا من كل ما يؤذيها أو يضرها، وكل هذا لا يتأتى إلا بالتمسك بدين الله وشرائعه وأحكامه، وعلينا الثزود بتقوى الله

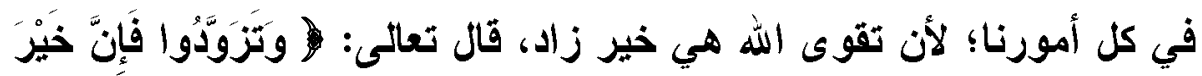

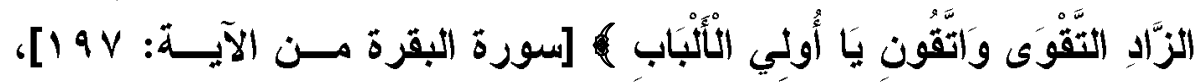
جاء في تفسيز الطبري: التقوى عمل بطاعة الله، وخص سبحاته أصــحاب

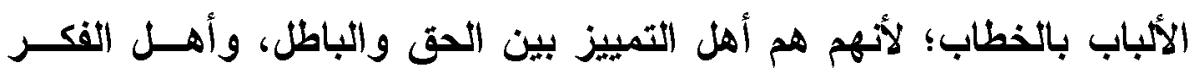
الصحيح والمعرفة بحقائق الأثياء التي بالعقول تلرك وبالألباب تفهم (1). 


\section{الإبمث الثاني}

\section{وسطية التشريع الإسلاهي في تهقيق الأهن الفكري}

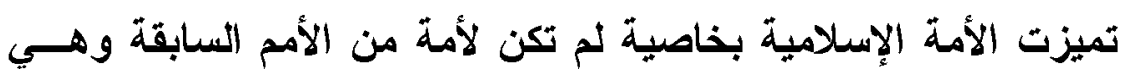

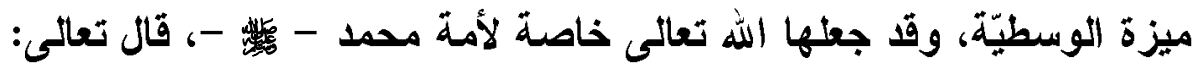

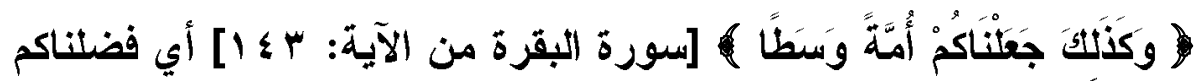
عثى من سواكم من أهل الملل، كما فضيَّناكم على غيركم من أهل الأديــان،

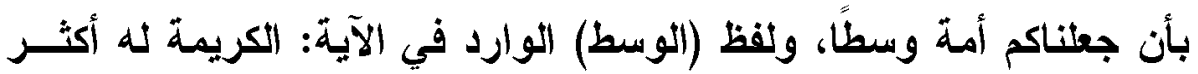
من مدلول، فهو بمعنى البينية، والعدل، والخيرية، ومعنى الأمة الوسط أنها

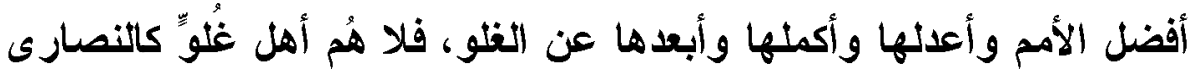
الأين غلوا بالتزرهب، وقالو أفي عيسى ما قالوا فيه، ولا هُم أهـلـل تقصــيز كاليهود الأين بلَّلوا كتابَ الله، وقتلوا أنبياءهم، وكذبوا عثلى ربهم، وكفروا بـه؛ ولكنهم أهل توسط واعتدال فيه، فوصفهم الله بذلثك، إذ كان أحبَّ الأمور إلى الله أونسطُهاب(1). والأمـة الإسـلامية بوصفها أمسة وسطا فهي بذألك تحمل أثــمل وأكمـل وأقوم منهج في العقيدة والأخلاق والتشريع ...، وهو الاين الإسلامي الأي

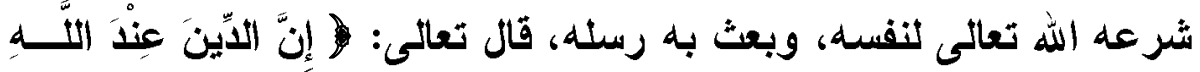
الإسلام ) [سورة آل عمران من الآية: 9 1]]، ومما يـلدل على وسطية وشمول وكمال وقوامة هذا الديز ما يلي: 1. أنه نهى عن الثرث وأمر بعبادة الله إلها واحدا لا شريك له، وبذلك مايك يكون قـ حرر العقول من الجهل والضلال والبدع والخرافات، وقا ميّز

$$
\text { (1) تفسير الطبري: ر/ إك أ وما بعدها. }
$$




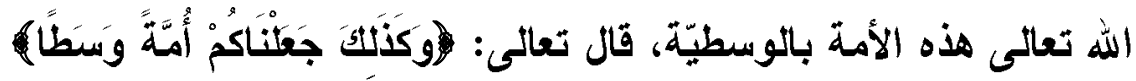

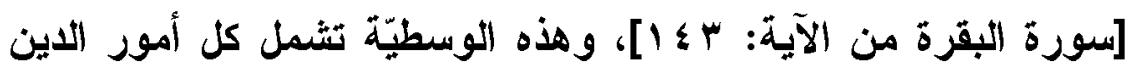

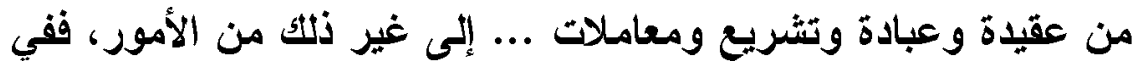

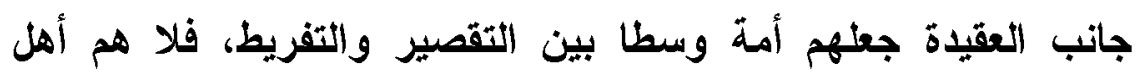
غلو، ولا هم أهل تقصير، وكلنا بطلم مدى غلو أو تقدي القصير الأمم العابقة

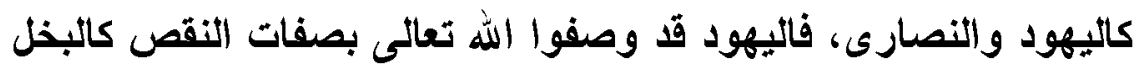

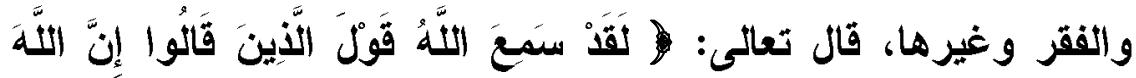

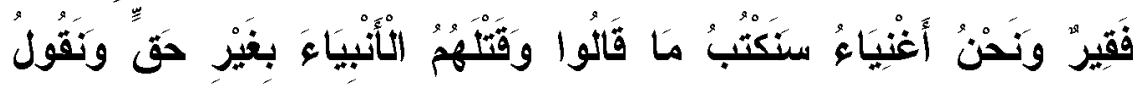

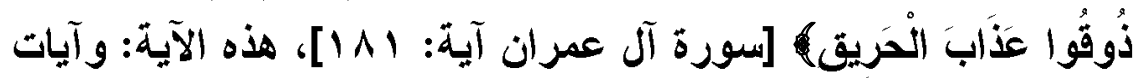

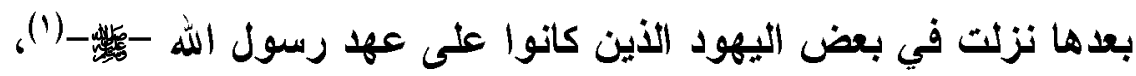

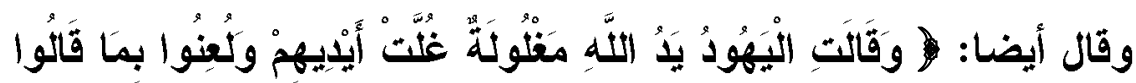

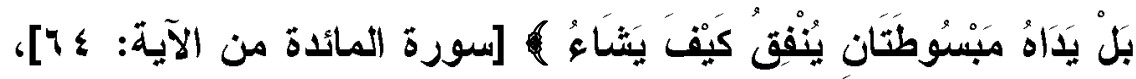

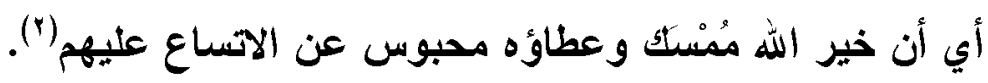

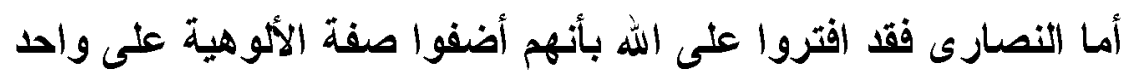

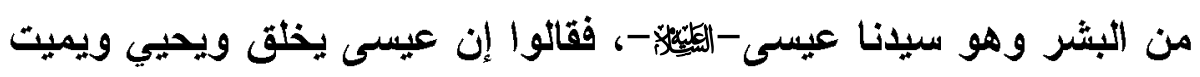

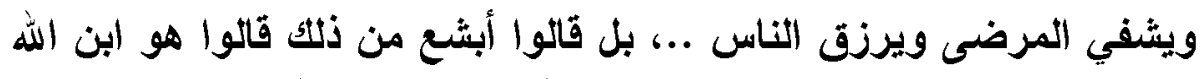

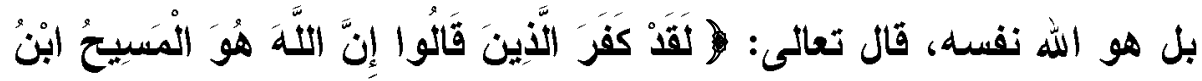

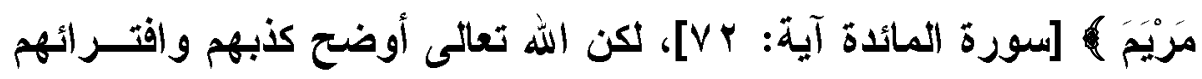

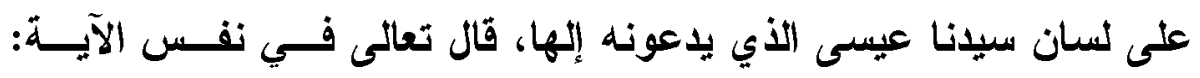

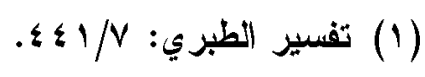

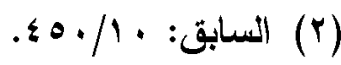

\section{0r}

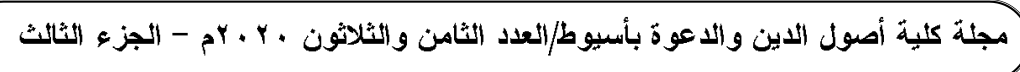




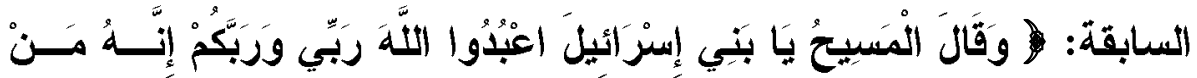

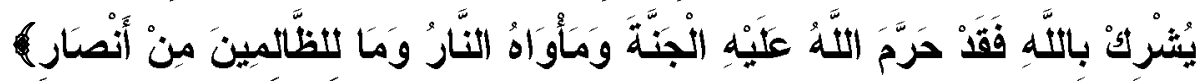

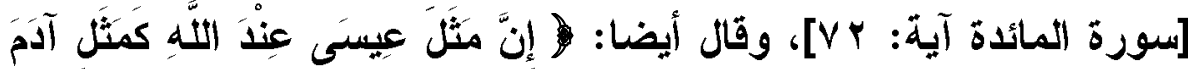

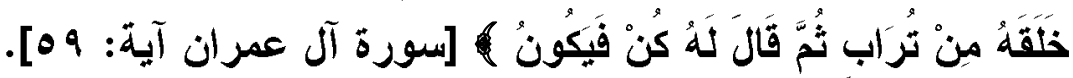
و القر آن الكريم مليء بالآيات التي تدل على افترائهر على الله تعسالى،

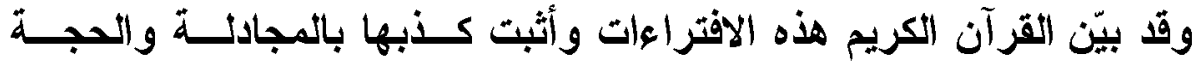

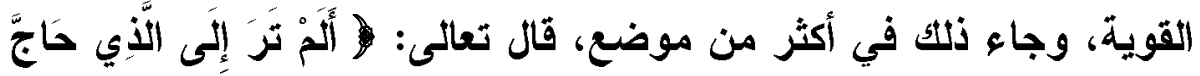

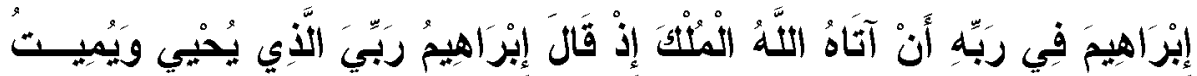

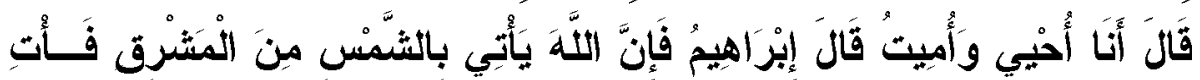

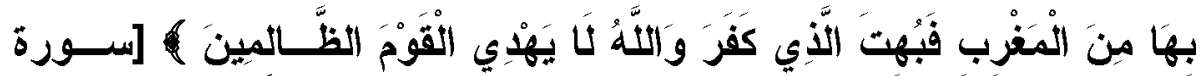

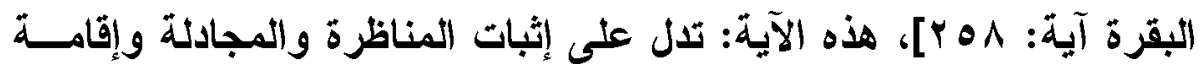

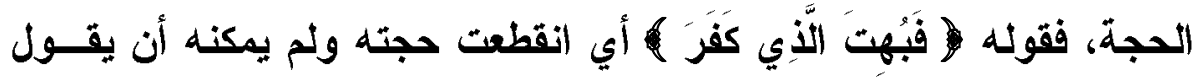

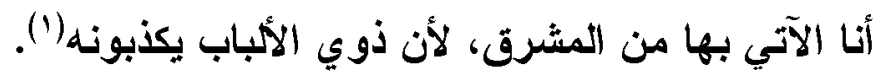

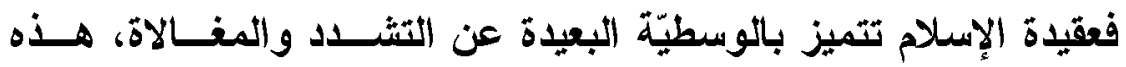

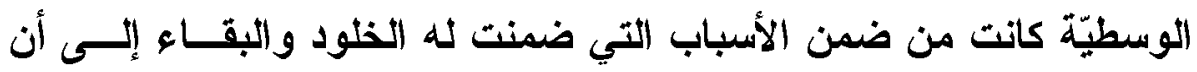
يرث لله الأرض ومن عليها. والوسطيّة لم تثمل العقيدة فقط، وإنما شمثت كل جوانب هذا الدين من

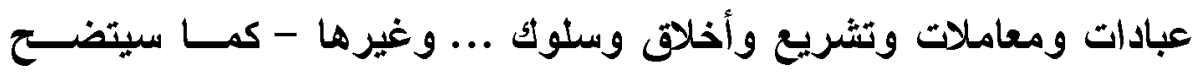

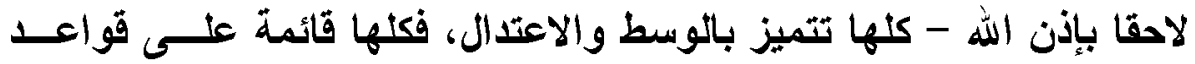

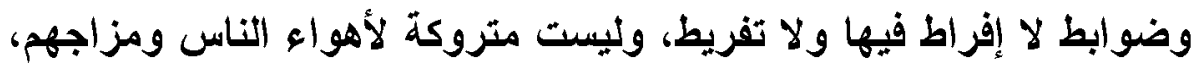


بل موضوعة من لان حكيم خبيز

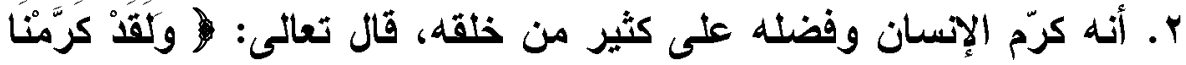

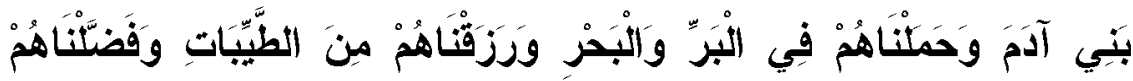

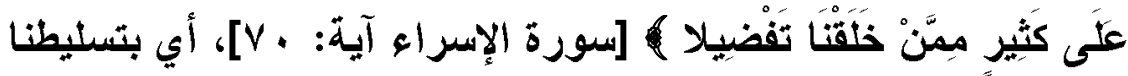
إياهم على غيرهم من الخلق، وتسخيرنا سائر الخلق لهم(")، وهذا التكريم له العديد من الصور والأشثكال منها: ميزه بالعقل الذي يفكر به

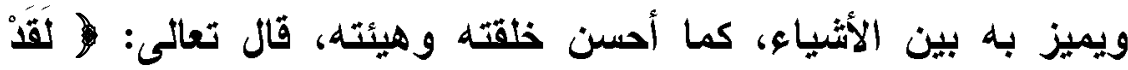

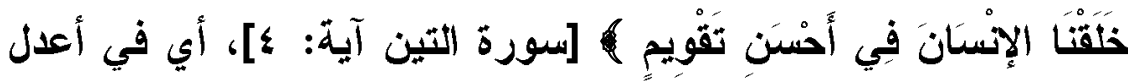
خلق وأحسن صورة(†)، كما سخر كل ما في الكون لخدمته ولمنفعته، قال تعالى في سورة النحل

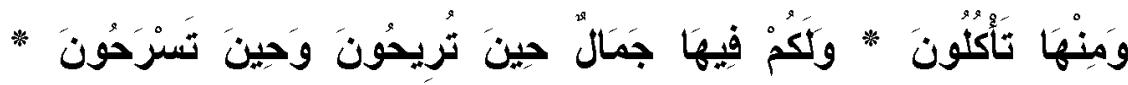

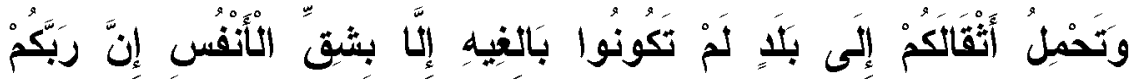

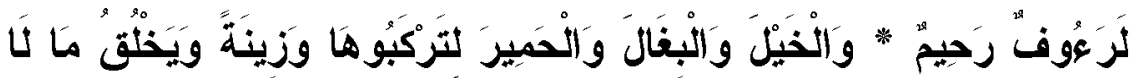

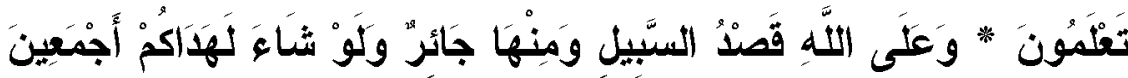

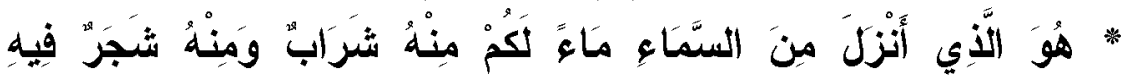

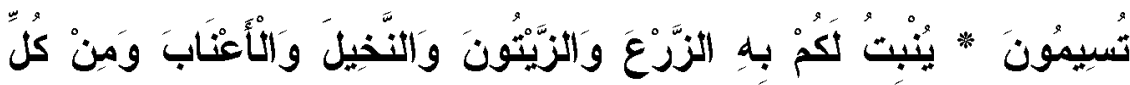

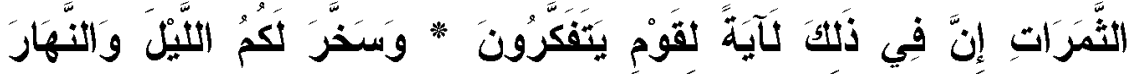

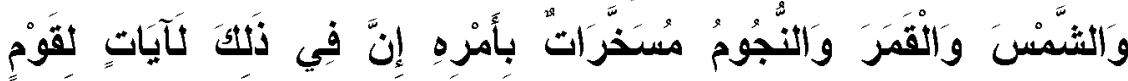

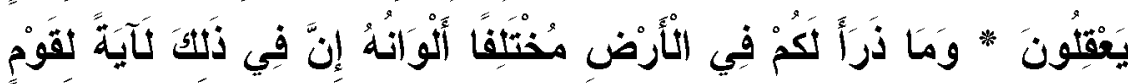

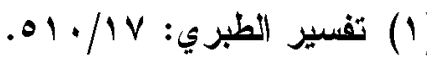

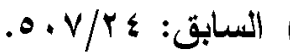




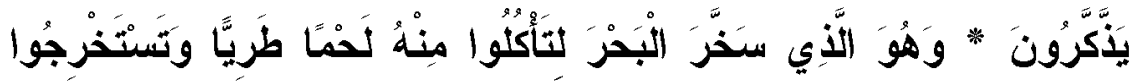

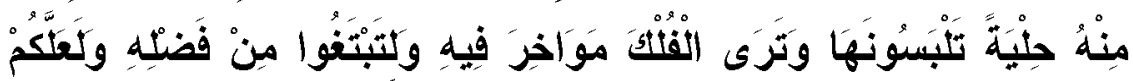

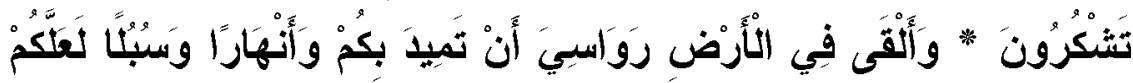

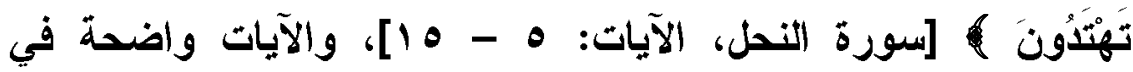

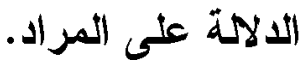

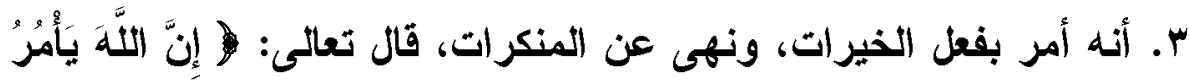

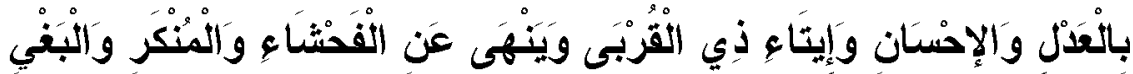

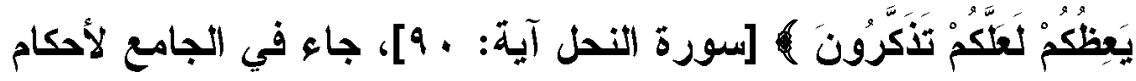

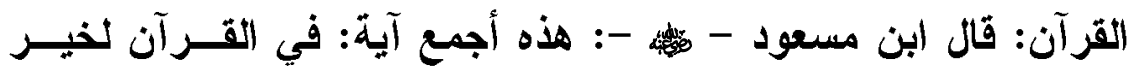

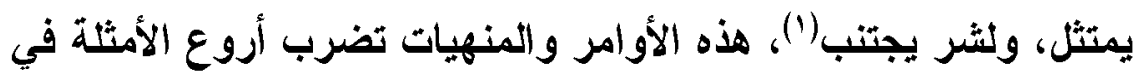
وسطية هذا الداين واعتداله. ؛. أن الله تعالى قد شرع العبادات والفرائض للتقرب لله سبحانه وتعالى، وتتميز العبادات المفروضة ونوافلها في الإسلام من طهارة وصلاة

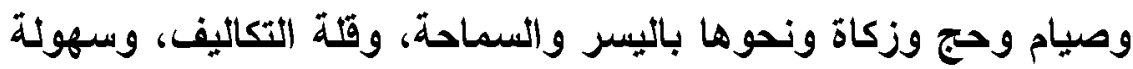
الممارسة، والبع عن التثلدد والظلو والتنطع، وكون المثقة فيها معتادة، فضلا عن فوائدها الجمة، وآثارها التهذيبية والاجتماعية، ونية

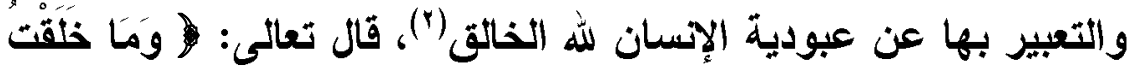

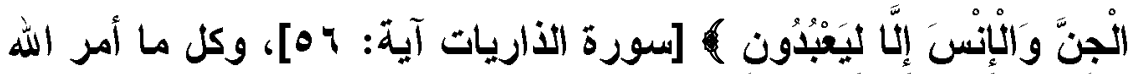

$$
\text { (1) تفسير القرطبي: • 19/1) }
$$

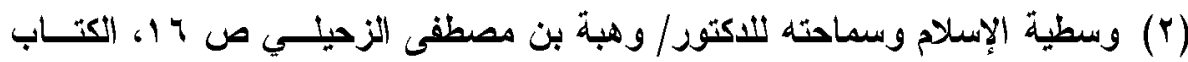
منشور على هوقع وزارة الأوقاف السعودية بدون بيانات.

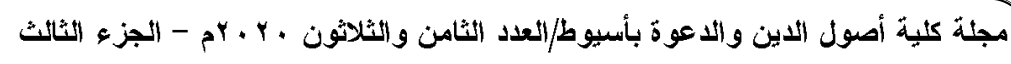


تعالى به خير، فأمر بالطهارة؛ لأن فيها حماية للنفس وسلامتها، ووقاية من المؤذيات وكل ما بضر، وأمر بالصلاة التي هي صلة بين العبد وربه؛ ليجعل المؤمن على صلة دائمة بربه يلجأ إليه في كل وقت في في وفي أي مكان دون حدود أو قيود، وأمر بالصوم وما فيه من صبر وإرادة وعزيمة وقوة تحمل عثى الإمساك عن كل الثهوات، وأمر بالزكاة؛ لتحقيق التكافل الاجتماعي والتعاون بين أبناء المجتمع الواحد، وفيها علاج لكثير من الأمراض الاجتماعية كالفقر والغل والحقد ... وغيرها، وأمر بالحج الذي فيه منافع كثيرة، والتقاء للمسلمين من جميع أرجاء المعمورة عرب وعجم؛ ليلبوا دعوة الله تعالى ويذكروا الله في أيام معلومات ... وهكذا، فلم يُشرع الله تعالى شيئا إلا وفيه حكم ومنافع كثيرة للناس. وعلى الرغم من تثريع الله تعالى للعبادات للتقرب لله سبحانه وعبادته إلا أنه نهى عن الغلو والتشدد في آدائها، فثرعت الرخص تخفيفا، فمن لم يستطع الصلاة قائما فجالسا، أو مستلقيا، ومن لم يستطع الصوم لمرض أو سفر أو غيره، فعليه الإفطار والقضاء متى زال العذر، ومن لا يملك النصاب الثرعي النامي في الزكاة، فليس عليه زكاة، ومن يفقد القدرة الماليـــة أو

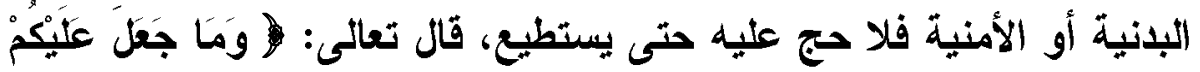

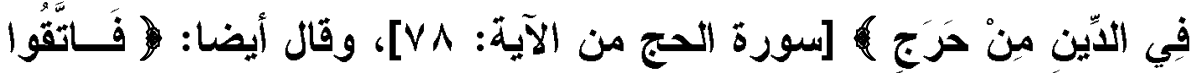

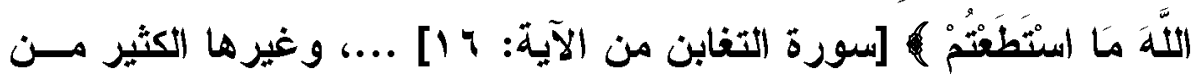
الآيات التي تدل على التيسير ورفع الحرج. ولو تأملنا العبادات لوجدنا تحقق معنى الوسطيّة فيها، فلم يجعـل الله

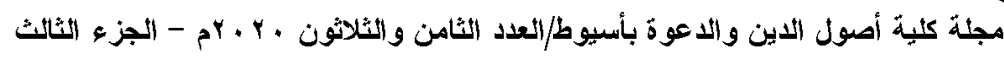


تعالمى اليوم كله صلاة، أو أيام العام كله صوم، أو إخراج المال كثـــه فــي الزكاة، أو وجوب الحج كل عام، ولكن جعل أداء هذه العبادات بقدر يسـير، وللمستطيع على أدائها فقط، وشرع الرخص للتيسير، فالصدلاة خمس فـي اليوم والليدة، والصوم المفروض شهر واحد فقط من شهور العام، والزكاة

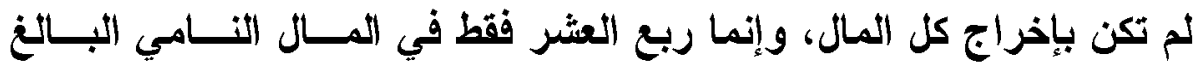

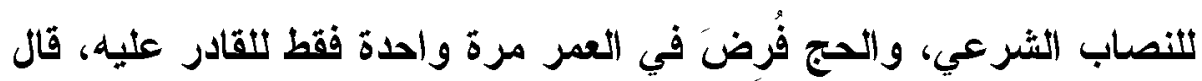

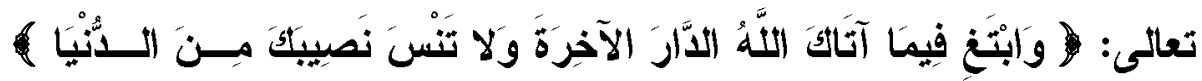
[سورة القصص من الآية: VVV]، ومعناه لا تضيع حظك من دنياكك في تمتعك بالحلال وطلبك إياه(')، وعن النهي عن التشدد في العبادة جاء فـي الســة فئة

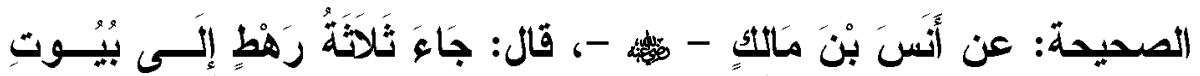

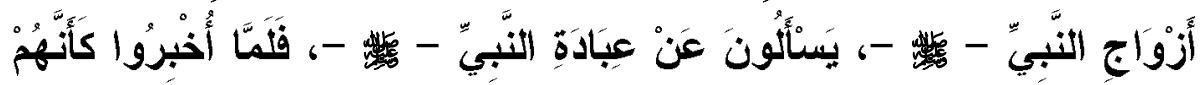

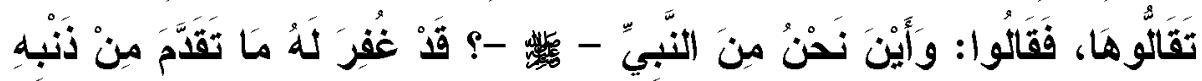

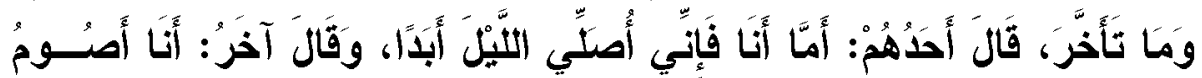

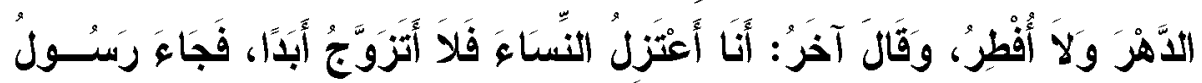

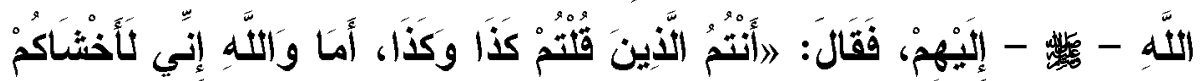

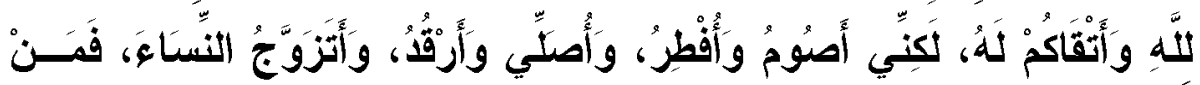

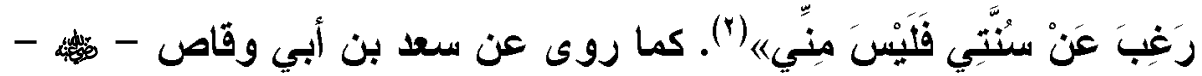

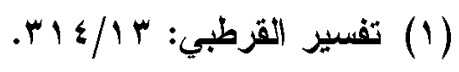

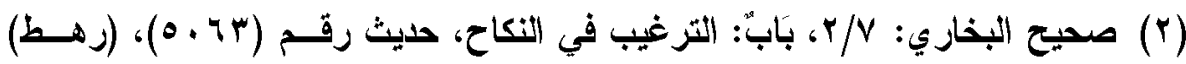

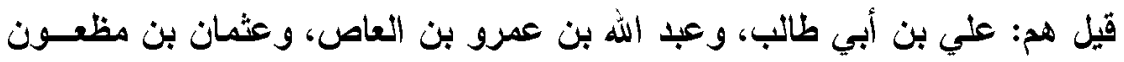

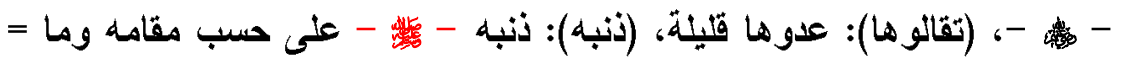

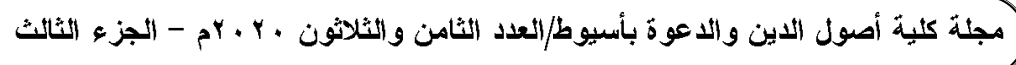




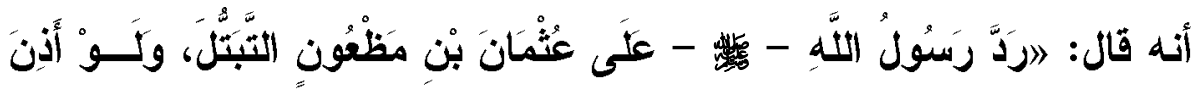

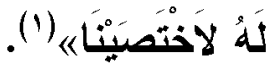

ه. حافظ على حقوق الإنسان كلها، وحرم الاعتذاء على النفس البثرية

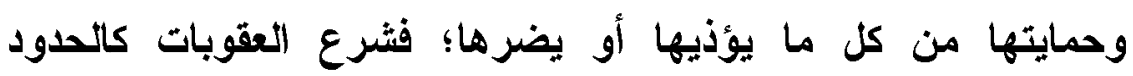

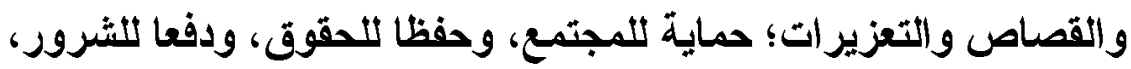

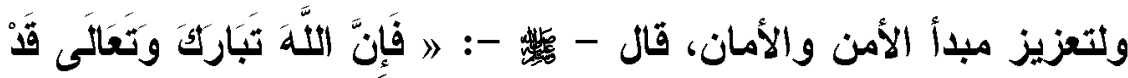

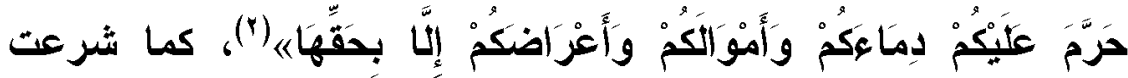

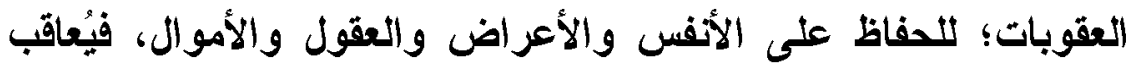

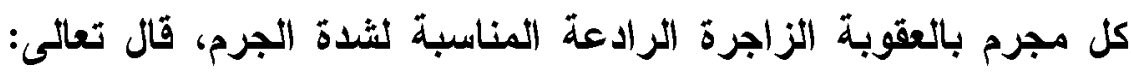

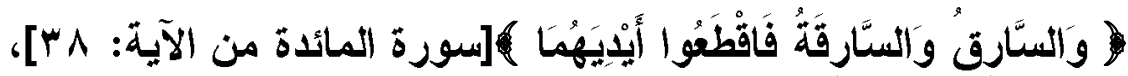

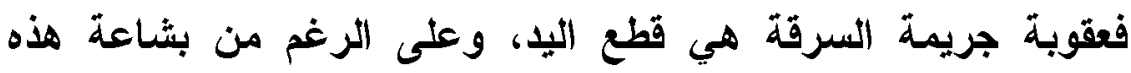

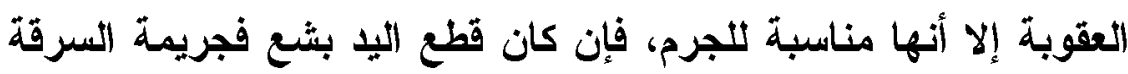

= يعتبر ذنبا في حقه ليس هو من جنس الأنوب حقيقة ولو فعله غيره لا يســى

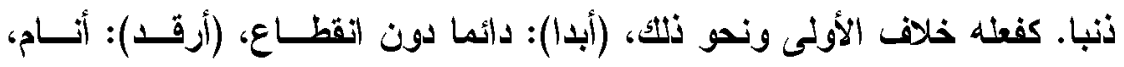

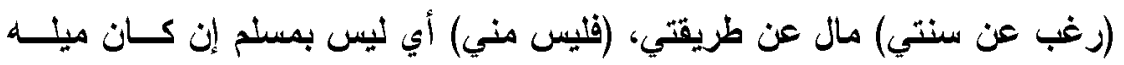

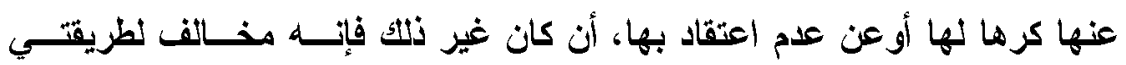

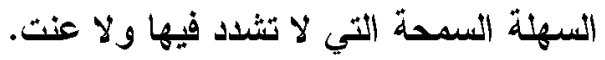

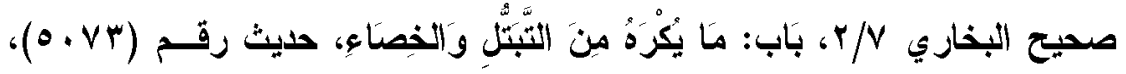
(رد) لم يأنن ومنع ونهه، (التبتل) الأقطاع عن النساء وترك الأزواج، (لاختصينا)

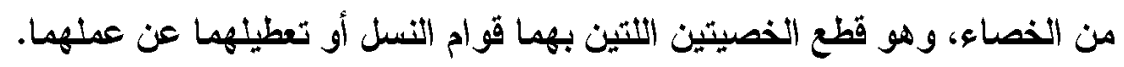

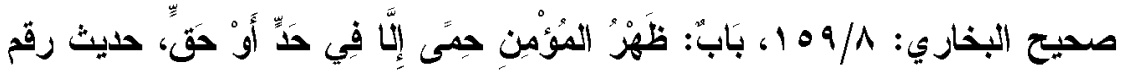

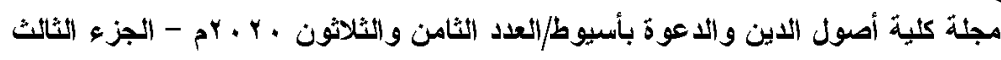


أبثع؛ لأن فيها انتهاك للحرمات التي أمر الله بعدم انتهاكها، وفيها أخذ أموال الغير بدون وجه حث، وقد يترتب على جريمة اللسرقة جرائم

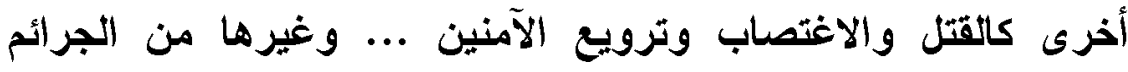

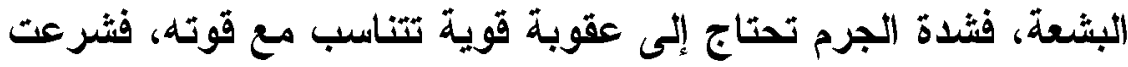
هذه العقوبة وغير ها من عقوبات الحدود والقصاص و التعزيرات؛ حماية للحقوق، وصيانة لمقاصد الثريعة وهي: الاين والنفس والعقل

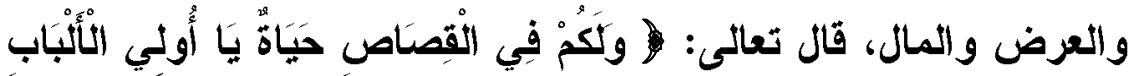

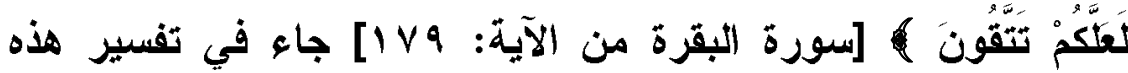

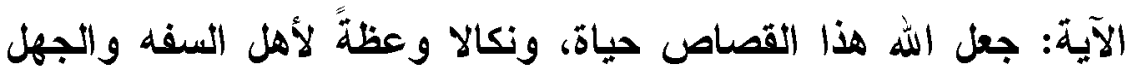

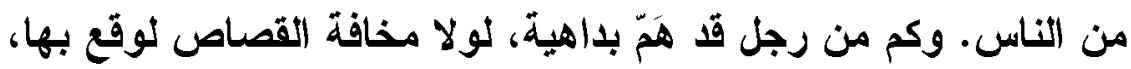
ولكن الله حَز بالقصاص بعضهم عن بعض؛ وما أمر الله بأمر قط إلا

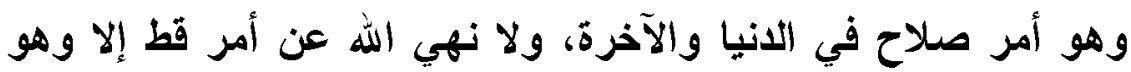

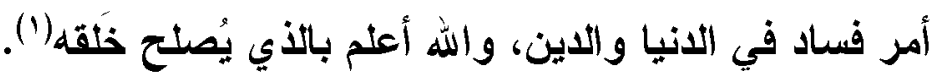

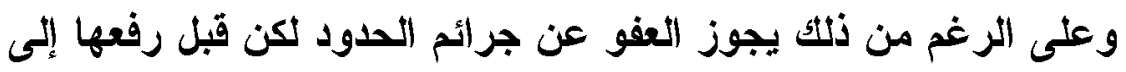
الإمام، كما يجوز العفو في القصاص، ويجوز العفو في الاية، قال تعسالى:

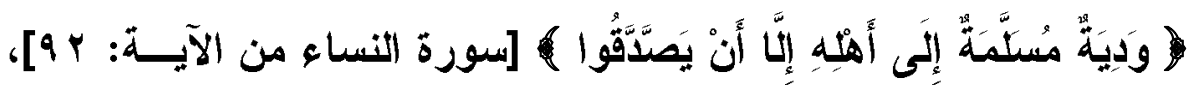

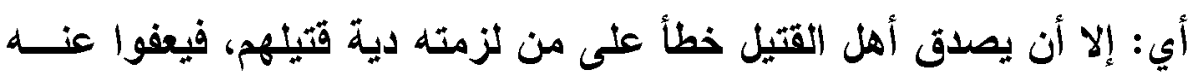

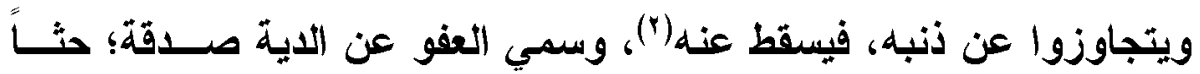

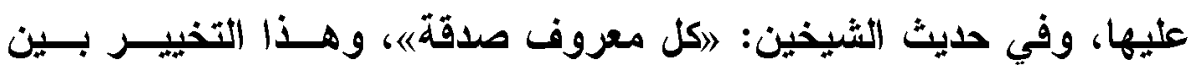

$$
\begin{aligned}
& \text { 1) تفسير الطبري: بر/r }
\end{aligned}
$$

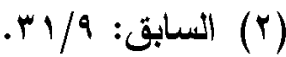


عقوبة القصاص والاية والعفو مما تميزت بـه شريعتنا الإسـلامية؛ للالالـــة على الوسطيّة والاعتدال، فقد شرع القصاص وحده في الايانتة اليهوديـــة،

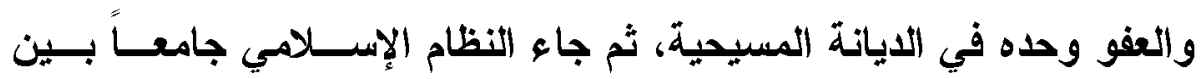
المزايا كلها، لإبقاء صنائع المعروف والمودة والفضيلة، وتقليـل تطبيـق الاعقوبة، وجله هو الثائع بين الناس (1). وذم تكن المحافظة على النفس البشرية حال الحياة فقط، بل بعد الممات

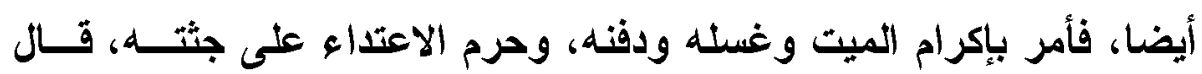
ج. ولم يكتف بحفظ حقوق الإنسان فقط، بل راعى ذلك في كل كائن حي

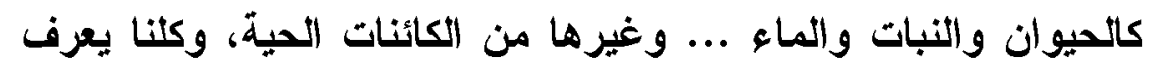

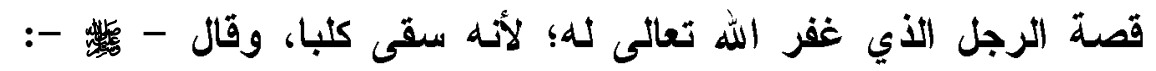

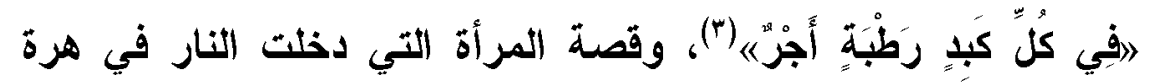

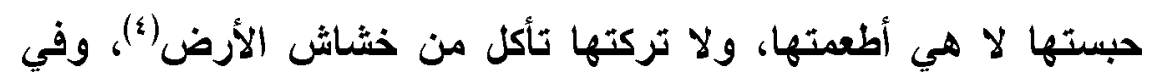

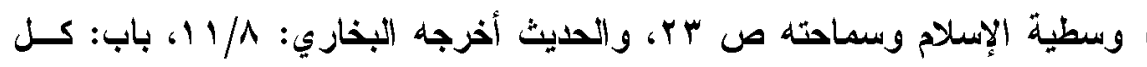

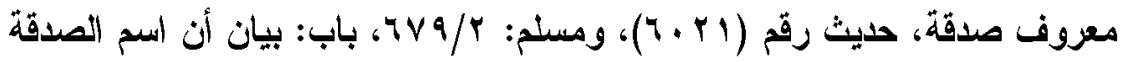

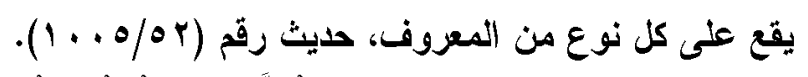

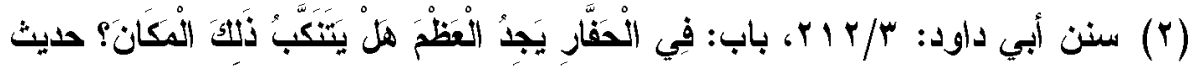

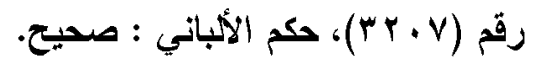

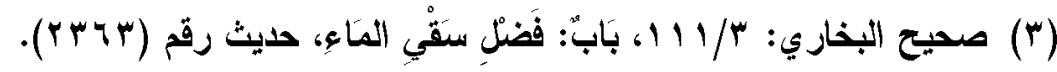

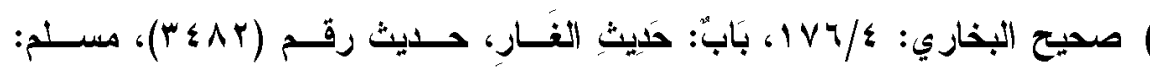

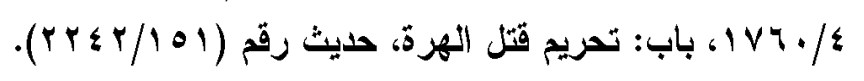


النبات حرّم قطع الثجر وحرق التبات بلا سبب، وفي الماء أمر بالمحافظة عليها وعدم الإسراف في استعمالها، وأوضح أهميتها لكل

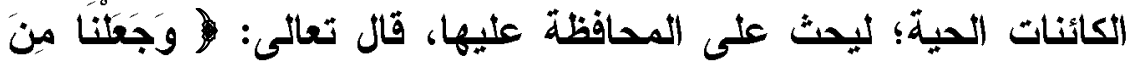

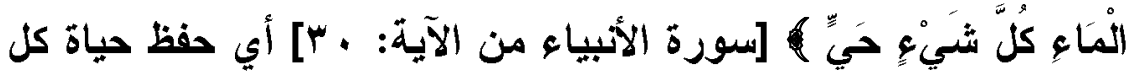
شيء بالماء)"، و هكذا التعامل مـ كل كائن حي، أمر الله تعالى بالمحافظة عليه، ومراعاة حقوقه، وعدم التعدي عليه بأي صورة من الصور . V. أيضا مما يدل على وسطية الإسـلام أنه نظم العلاقات المالية بين الناس وبعضها، فأباح البيوع والتجارات، ونهى عن الغث والتدليس والربا،

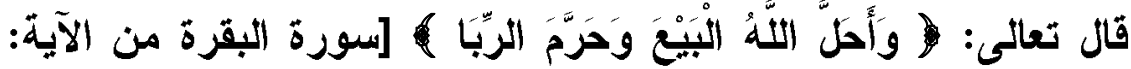

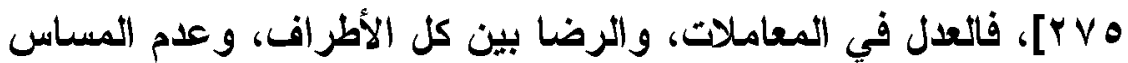
بحقوق الآخرين، والوفاء بالاعقود هو أساس فقه المعاملات المالية في

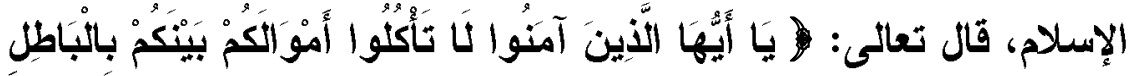

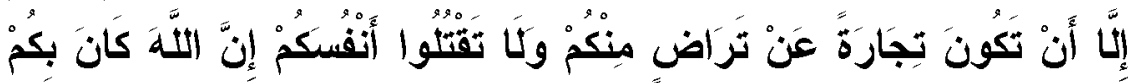

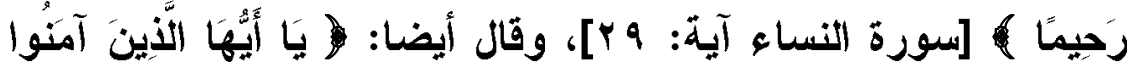

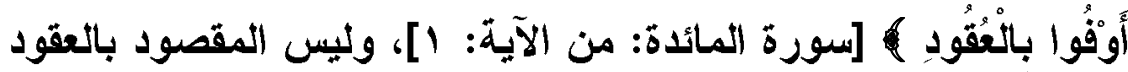
هنا هي العقود التجارية فقط، لكن العقود لفظ شامل لكل العهود التي بين العبد وربه - كما أوضحت سابقا -، أيضا مما بذل على وسطية هذا النظام المالي أنه يقوم على مبلأ الحرية الاقتصادية، ما لم يخالف الثرع، فكل فرد من حقه الكسب الحر مادام مشروعا وغير محرم، قال 


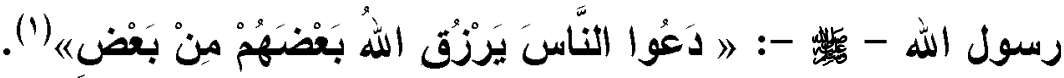
^. مما يذل على وسطية الإسلام أيضا: أنه حمى أموال اليتامى والضعفاء؛ فحد المواريث، ونهى عن أكل مال اليتيم؛ حفظا للحقوق، وتحقيقا

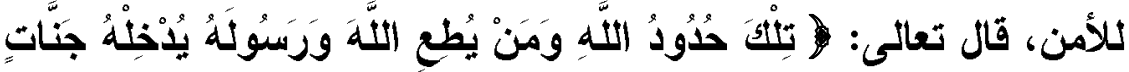

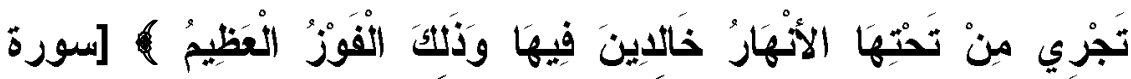

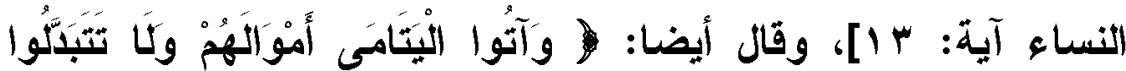

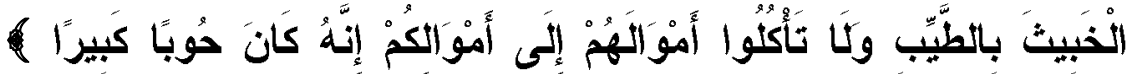

$$
\text { [سورة النساء آية: بـ }
$$

9. كما في إباحة الطيبات من المأكل والمشرب والملبس والمسكن، وتحريم

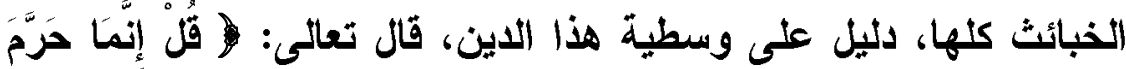

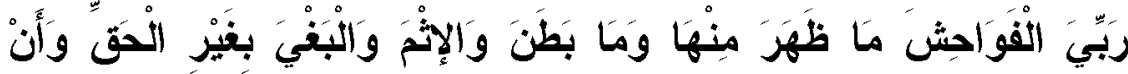

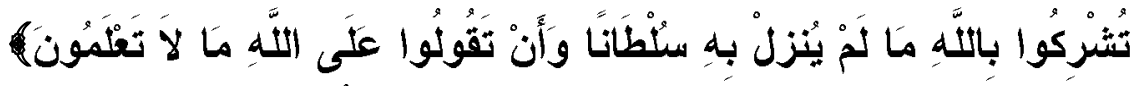

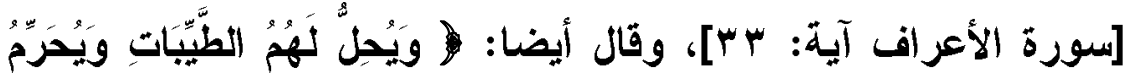

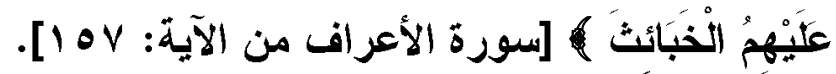
• ا. من وسطيته أيضا: أنه رتب العلاقات الأسرية والاجتماعية من نكاح وطلاق وعدة ونفقة ... وغيرها، وبيّن أن هذه حدود الله، وأمر

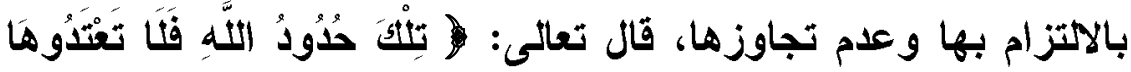

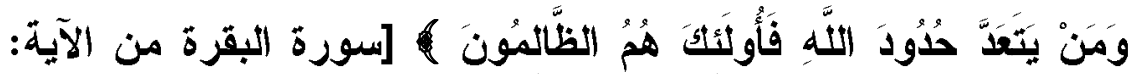

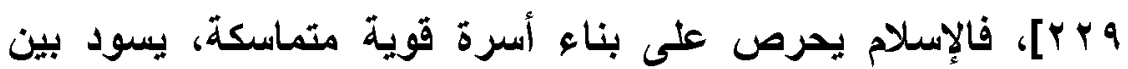

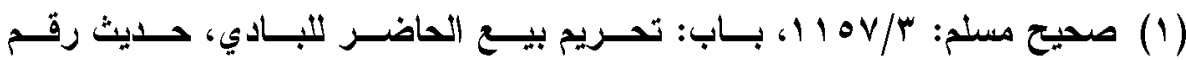
.$(1 \circ Y r / T \cdot)$ 
أفرادها قيم التعاون والتراحم والاحترام، قال تعالى: وَمَنْ آيَاتِهِهِ أَنْ

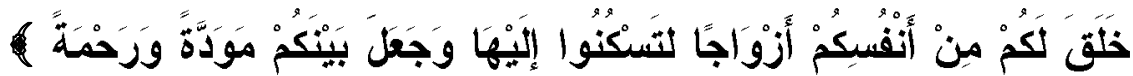

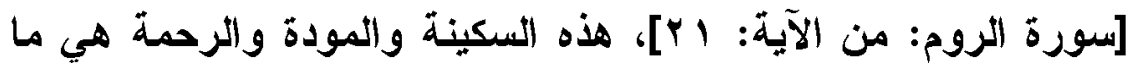
يحقق الخير والسعادة للأسر المسلمة. 1 ا.عمل على نشر قيم العدل والخيز والمساواة والحب والرحمة بين

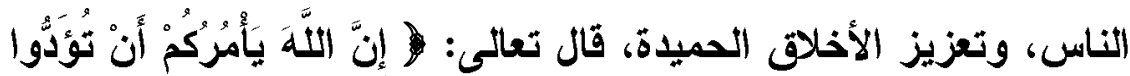

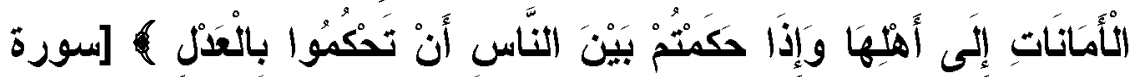
النساء من الآية: هـ]، ومن المعروف أن الحياة الإنسانية لا تستقم وترقى وتزدهر إلا بالتمسك بالأخلاق الإسلامية التي حث عليها دينتا

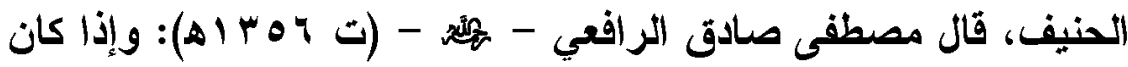
لا با للأمة في نهضتها من أن تتغير، فإن رجوعنا إلى الأخلاق الإسدلامية الكريمة أعظم ما يصلح لنا من التغير وما نصلح بـه منه، فلقد بُُ ما بينتا وبين بعضها، وانقطع ما بينا وبين البعض الآخر، وإذا نحن نبذنا لخمر، والفجور، والقمار، والكذب، والرياء، وإذا أنفنا من التخنث، والتبرج، والاستهتار بالمنكرات، والمبالغة في المجون، والسخف، والرقاعة، وإذا أخذنا في أسباب القوة، واصطنعنا الأخلاق

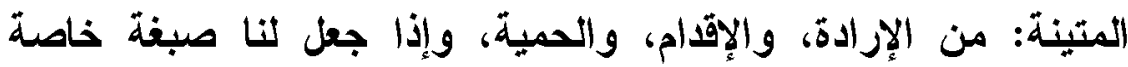

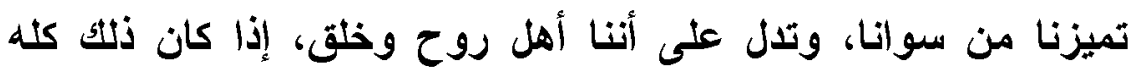
فلعمري أي ضير في ذللك كله، وهل تلأك إلا الأخلاق الإسلامية الصحيحة، وهل في الأرض نهضة ثابتة تقوم على غيرها؟ ('). (1) وحي القلم لمصطفى صادق الر افعي: r/ به 1، الناشر: دار الكتب العمية، الطبعة:

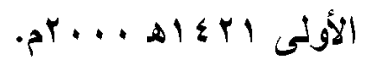

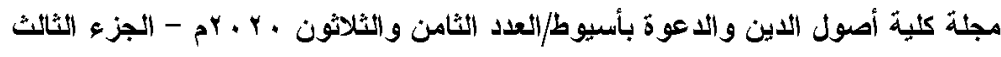


r أ.أمر بمراعاة حقوق الوالدين والزوجين والجار والفقراء والأجير.....

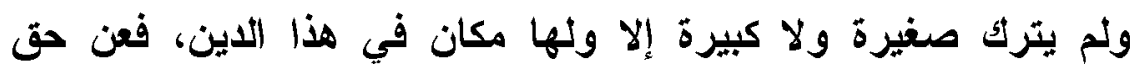

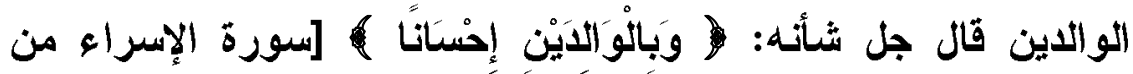

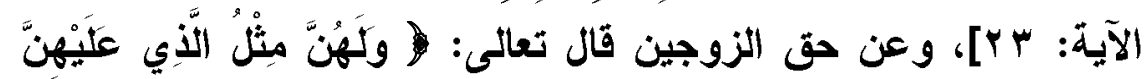

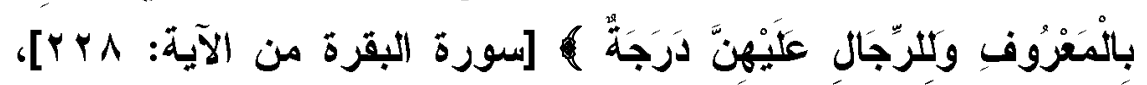

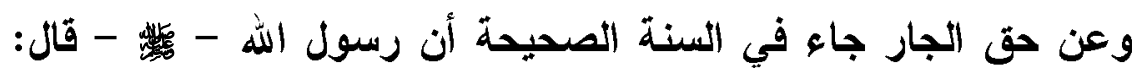

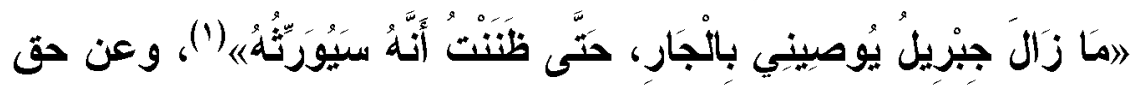

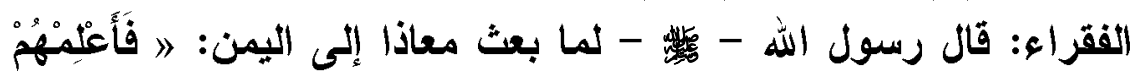

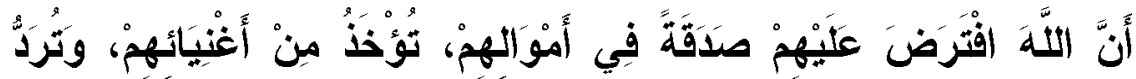

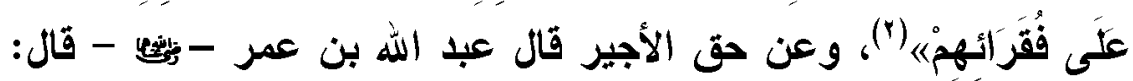

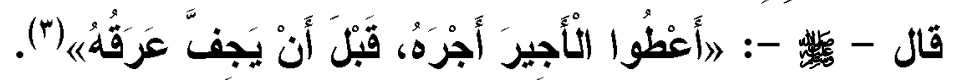

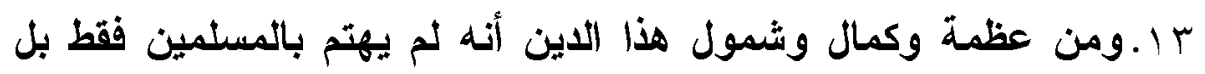

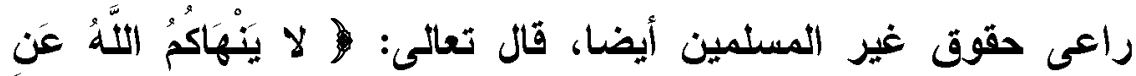

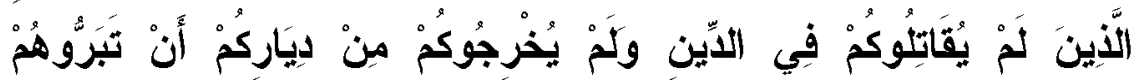

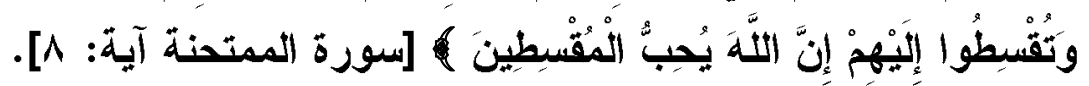

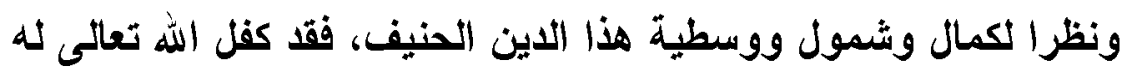
البقاء إلى أن يرث الله الأرض ومن عثلها، وهذه الصفات جعلتــه صـالحا

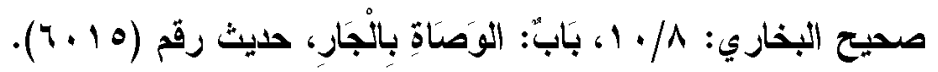

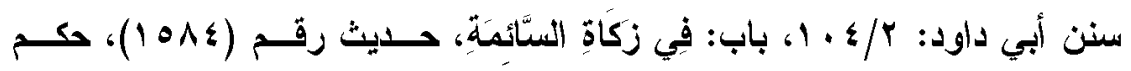

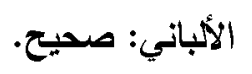

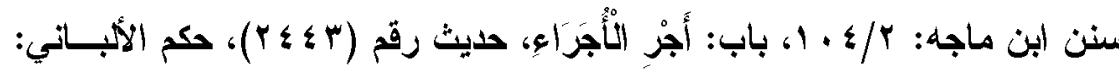

صحيح.

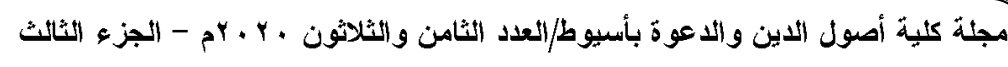


للتطبيق في كل زمان ومكان، وضمنت لله الخلــود، ويُعـد تطبيـق الــدين

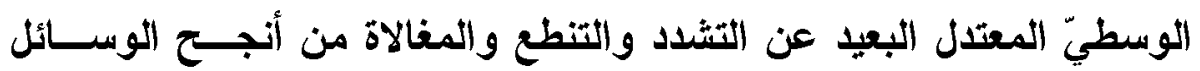
لتحقيق الأمن الفكري، وقد نهى الله تعالى عن الثلو في الاين؛ لأن الخغلـو

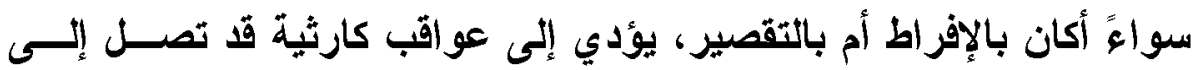
الكفر - والعياذ باله -، وهذا ما حدث مع أهل الكتاب من اليهود والنصارى بالهي

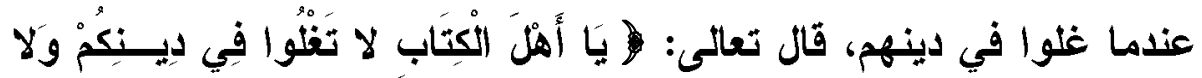

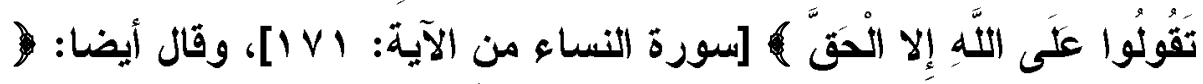

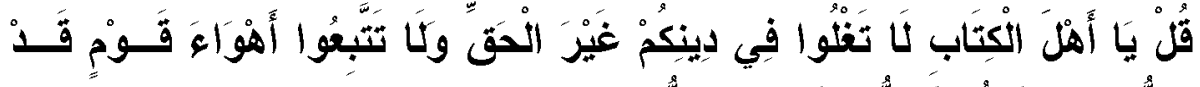

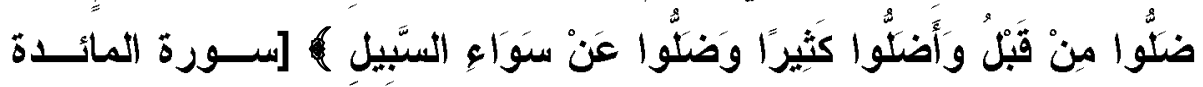

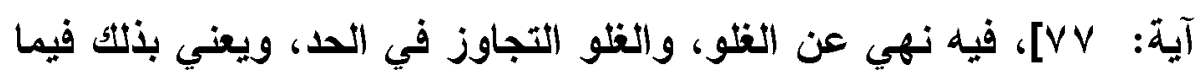

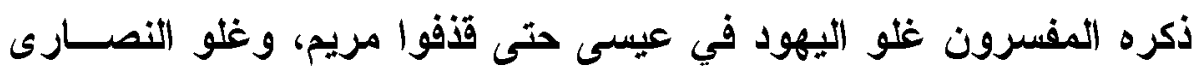
فيه حتى جعلوه ربا، فالإنزر اط والتقصير كله سيئة وكفر (').

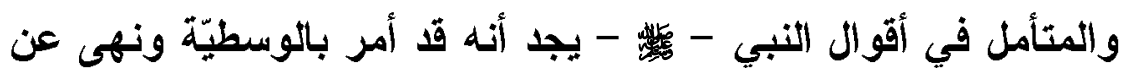

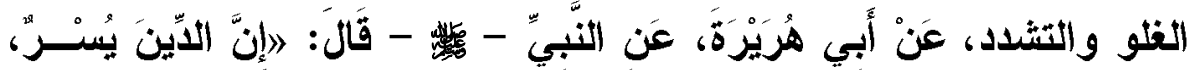

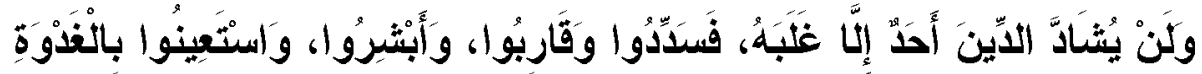

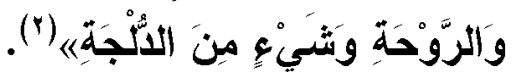

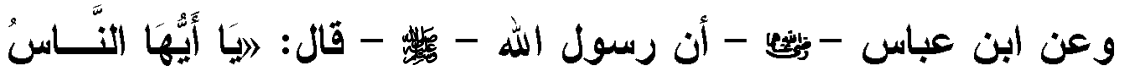

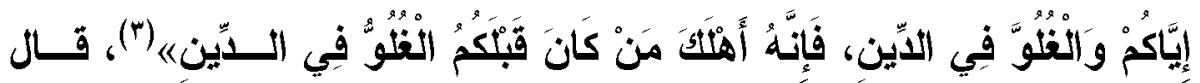

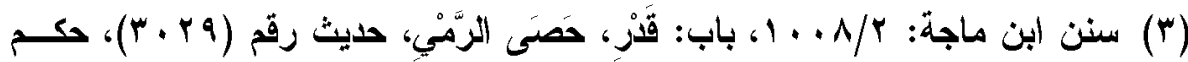
الألباني: صحيح. 
ابن تيمية - هوكة - : قوله (إياكم والغلو في الاين) عام في جميع أنــواع

الغلو في الاعتقادات والأعمال (1).

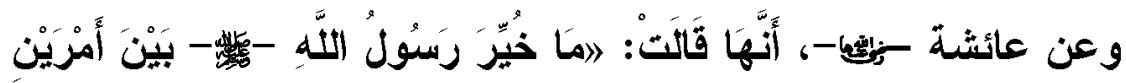

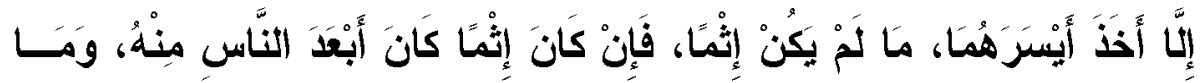

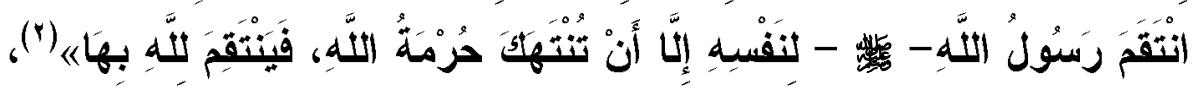

فيه استحباب الأخذ بالأيسر والأرفق ما لم يكن حراما أو مكروها(ثمان.

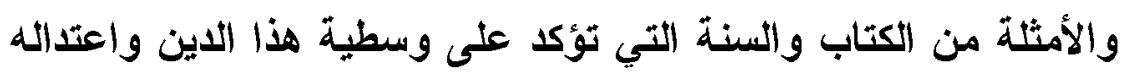

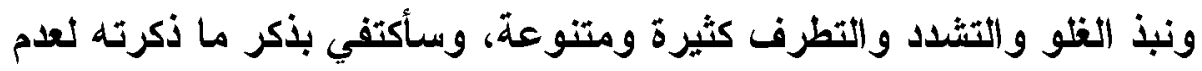

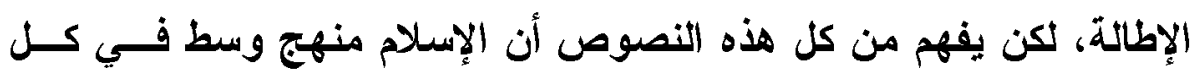

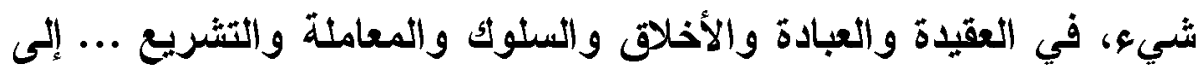
آخر تلثك الأمور.

واتباع وسطية الإسلام وتطبيقها في كل أمور حياتنا والبعد عن التثدد

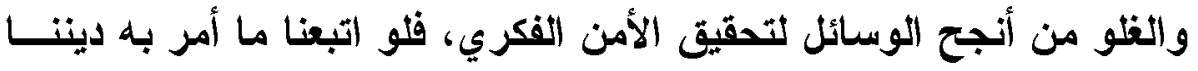

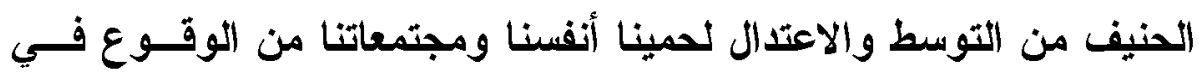

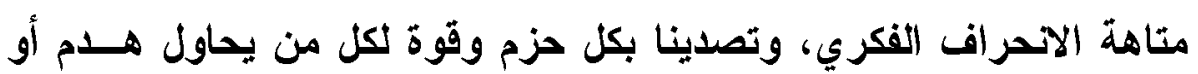

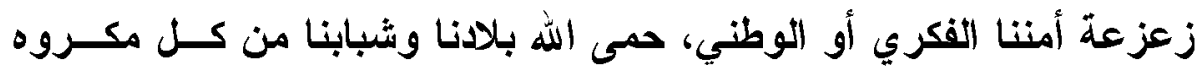

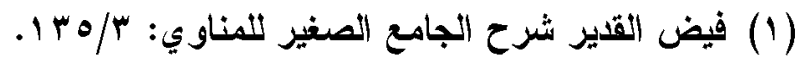

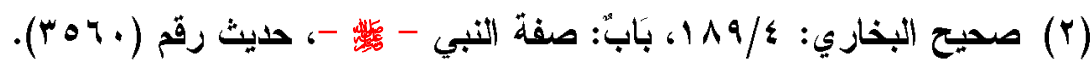

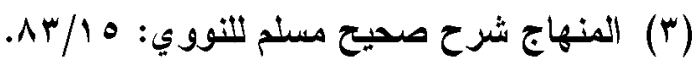

\section{7}

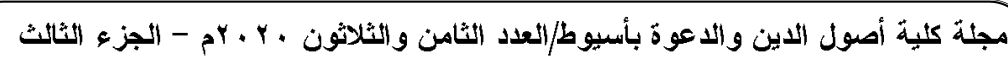




\section{الخاتمة}

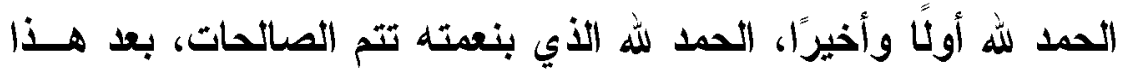

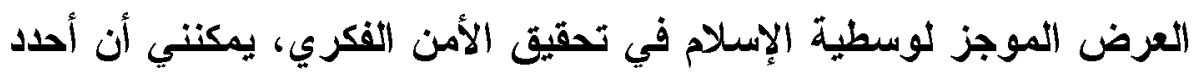
نتائج البحث في عدة نقاط، من أهمها:

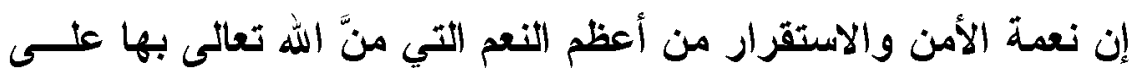

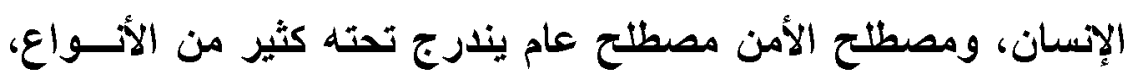

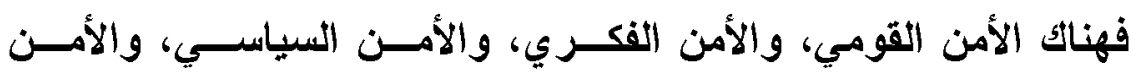

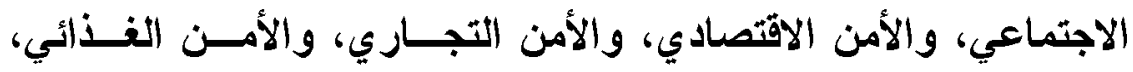

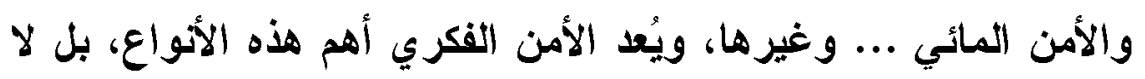

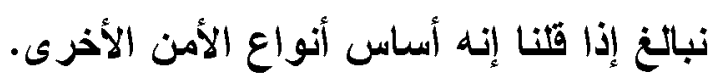

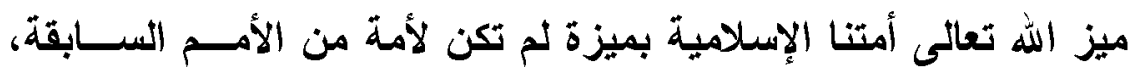

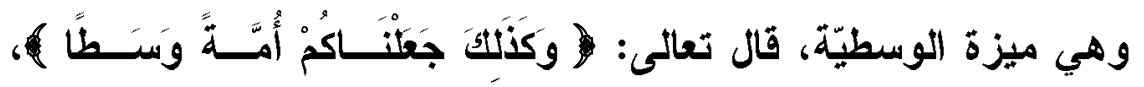

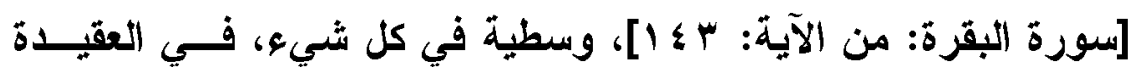

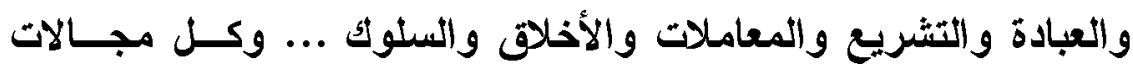

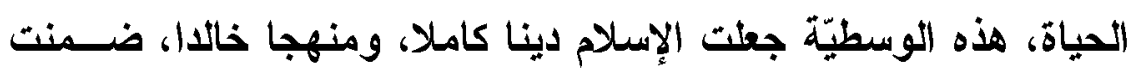

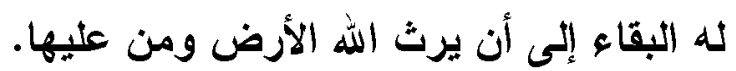
بين وسطية الإسلام وتحقيق الأمن الفكري علاقة قوية ووطيدة، علاقة الهة

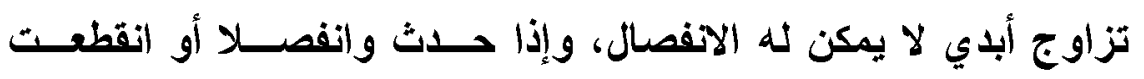

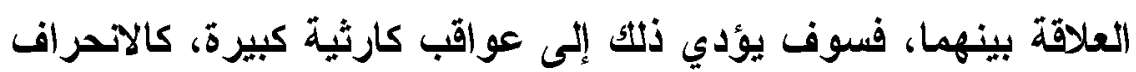
الفكري الأي يؤدي إلى تدمير المجتمعات والعياذ بالله.

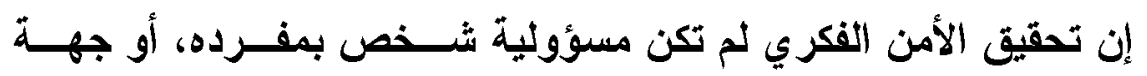


معينة، بل مسؤولية التاس جميعا بلا استثناء، ويجب على كل طوائـفـ المجتمع من هيئات ومؤسسات وأفراد وجماعات أن تتحــــ لمواجهـــة الاتحراف الفكري؛ لأن الحروب بين الدول - الآن - لم تصبح حروبَّـا

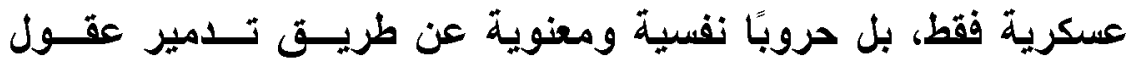
شبابها، وهذه أثتد خطرًا من الحروب العسكرية، فيجب التضــافر مــن الجميع بلا استثناء لمواجهة هذا الغزو الفكري الغاثم. من المعروف أن منافذ الغزو الفكري واسعة، أوسع من أن تحد بالطرق بع

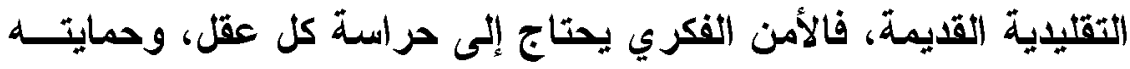
من الاختراق قدر الإمكان، والعلاج الناجح للانحراف الفكري يكمن فـي إنس علاج أسبابه ودو افعه. إن لصوص العقول والأقكار أثد خطرًا على الأمة من لصوص الأموال والممتلكات؛ لأن العقل هو الأسـاس، فلو فرّط الإتسان في عقله، وسيّمهـ للصوص العقل تسرقه وتوجهه كيفما شاعت، فقد أضاع كـلـ شــيء: نفسه ودينه وعرضه وكل ما يملتك، فأمنْ الفكر من أهم أنسـواع الأمسـن التي يجب المحافظة عليه، وحمايته من كل ما يشوهله أو يؤذيه. إن الإصلاح المرجو لابد وأن يقوم على مبأ الوسطيّة الإسلامية، بعيدا

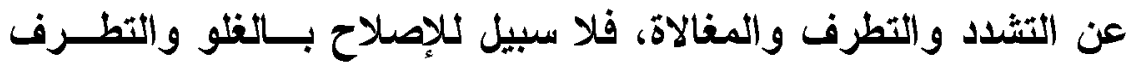
الأي ينتهجه بعض المرتزقة تحت مسمى الاين، والـــين بـريء مــن التثدد و التطرف والمغالاة، بل ينبذ التطرف والتثــدد وينهـى عنــه، فالاين الإسلامي دين وسط واعتدال ورحمسة ومسـودة ورفـث والــين وسماحة ويسر ودعوة حسنة، ولا سبيل للإصلاح إلا بتطبيق تعاليمسـه 
ومبادئه الوسطيّة السمحة.

فلا جدوى من محاولات الإصلاح إن لــــ تصــطبغ بصــبغة الوســـيّة الإسدلامية التي تكفل الحرية والمساواة للأفر اد والجماعــات، وتضــمن حقوق الإنسان كلها، ولا تنعزل عن العالم من حوثلها بل تتفاعل مـع مــا يحدث حولها من نقدم وتطور، وتتعايش مـــع الحضــارات والثقافــات الأخرى وفق مبادئها الوسطيّة السمحة.

أهم التوصيات:

أوصي بضرورة بذل الجهود العلمية من قبل العلماء والمتخصصين في التعريف بمبادئ الاين الإسلامي الوسطيّ البعيد عن التشدد والتعصــب والمغالاة، وذلك عن طريق عقد ندوات ومــؤتمرات توضـــح وســية الإسدلام وسماحته، وعدم إلقاء هذه الندوات والمؤتمرات محليا فقط، بل جعلها عالمية، وترجمة ما تتضمنه من بيان وسطية وسماحة الإســلام

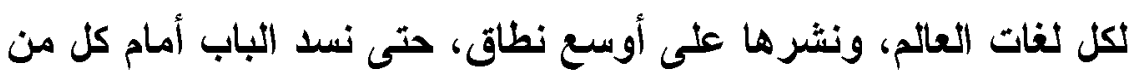
يحاول أن بشوه صورة هذا الاين الوسطيّ الحنيف. أُوصي بالاهتمام بالثبباب؛ لأن الثباب هم عصب الأمة وقوتها، فيجــب هـب على الاولة أن تتبنى المشروعات القومية لتوظيفهم واســتغلال وقـت فراغهم فيما ينفع، حتى يفيدوا أنفسهم وغيرهم. كما أُوصي بتفعيل دور الخطباء والوعاظ بالمســاجد التابعــة لـــوزارة الأوقاف، لأن دورهم في نثر مبادئ الاين الوسطيّ في غاية الأهميــة نظر القربهم من الناس البسطاء ووجودهم بينهم في كل وقت.

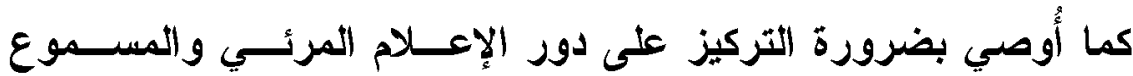

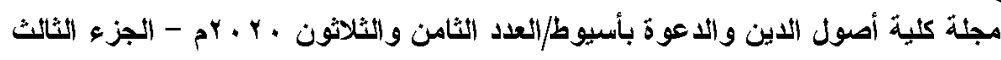


ووسائل التواصل الاجتماعي، فلإعلام دور كبير في غرس مبادئ الدين الوسطي" المعتدل، والتحذير من الغلو والتشدد والتعصب، والتحذير من هؤلاء المرتزقة الأين يبدعون في تزييف الحقائق والمتاجرة بالــدين؛ لتحقيق أغراض شخصية نابعة من هوى أنفسهم، أعاذ الله أمتنا مــنهم

$$
\text { ومن شرور هم. }
$$

كما أُوصي أبضا بضرورة لم شنمل أبناء الوطن الواحد، ومحاولة إزالة الفوارث بين الطبقات أو تقريبها؛ وذلك بإنثاء مشروعات لرفع مستوى

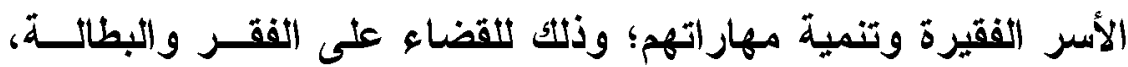
والاهتمام بمشروعات محو الأمية؛ لمحاربة الجهل، ورفــع المســتوى الاقتصادي والاجتماعي لأبناء المجتمع؛ حتى لا تُعطى الفرصة لأعـــــاء

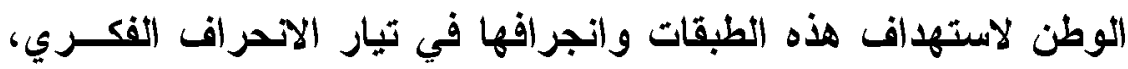

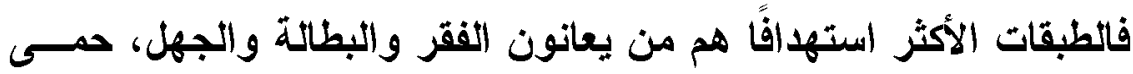
الله أمتنا وشبابنا وحفظهم بحفظه. وأخيزا: هذه محاولة لإبراز وسطية الإسلام في تحقيق الأمن الفكـري، فان أصبت فهزا من فضل الله عليّ، وإن كانت الأخرى فحسـبي أنسي بذلت جهاي واستطاعتي، وأن الكمال لله رب العالمين. والله أسأل أن يجعل هذا العمل خالصا لوجهه الكريم، والله مـن وراء القصد وهو الهادي إلى سواء السبيل.

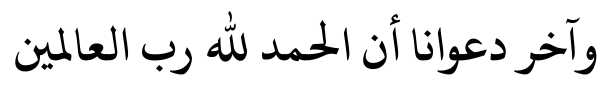

وصل اللهُهَّ وبارك على سيدنا محمد وعلى آله وصحبه ومن تبعهم أجمعين 


\section{المادر والمراجع}

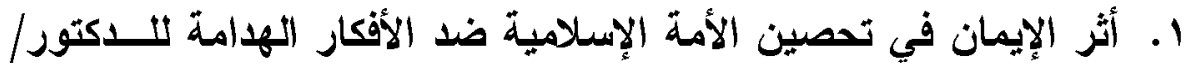

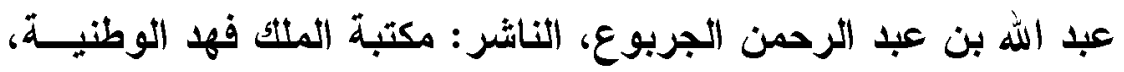

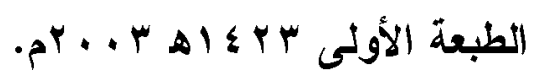

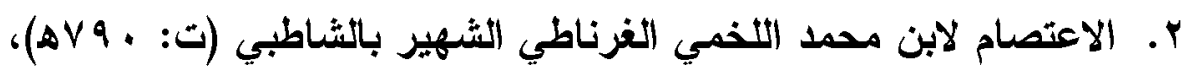

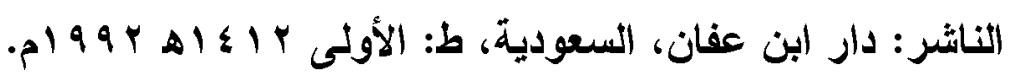

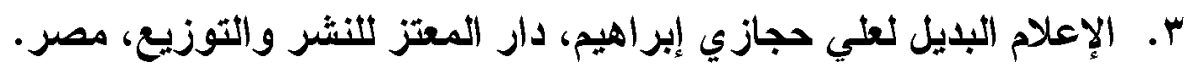

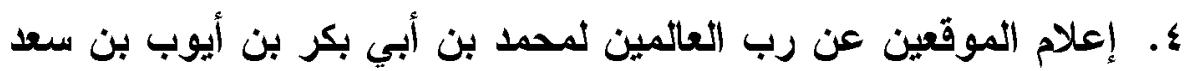

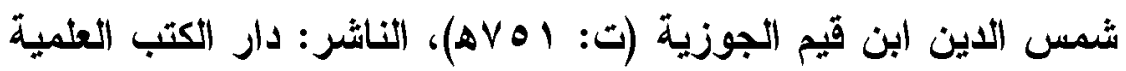

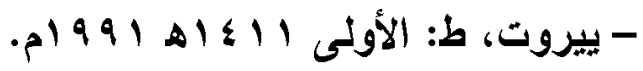

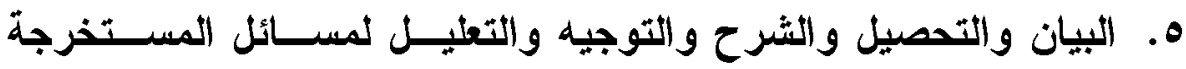

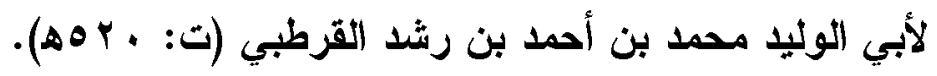

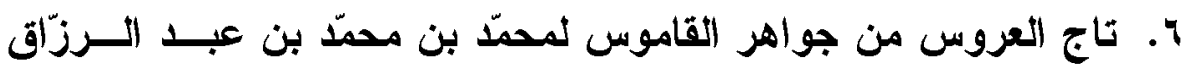

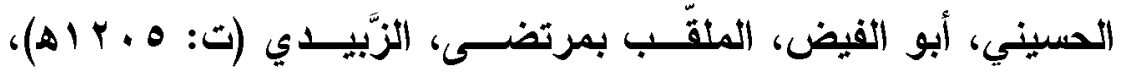
الناثر: دار الهـاية.

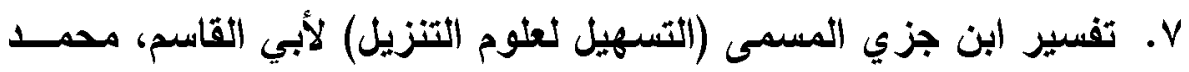

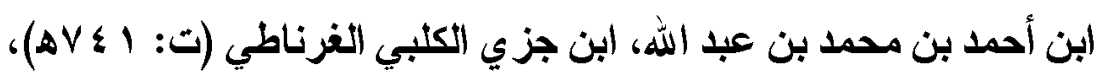

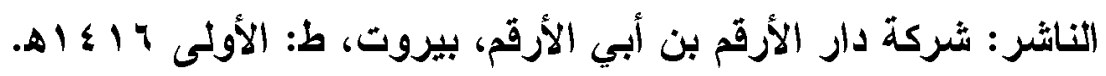

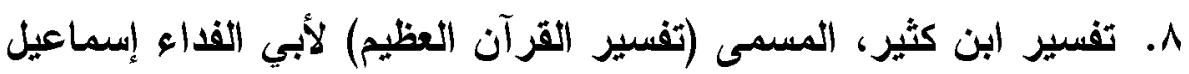

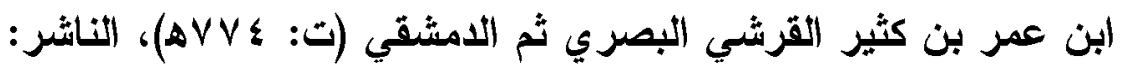

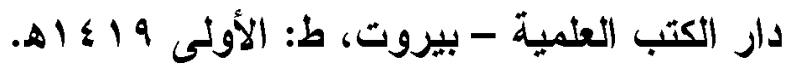

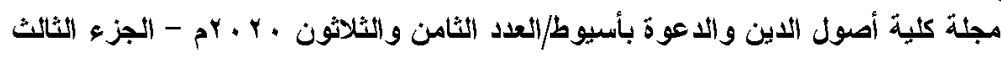


9. تفسير الرازي المسمى مفاتيح الغيب لأبي عبد الله محمـــ بـن عمــر ابن الحسن بن الحسين التيمي الرازي الملقب بفخــر الــدين الـــرازي خطيب الري (ت: 7 ، جه) التاثر: دار إحياء التراث العربي - بيروت،

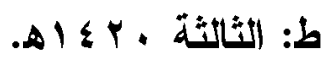
• ا.تفسير السعدي المسمى: (تيسير الكريم الرحمن في تفسير كلام المنان)

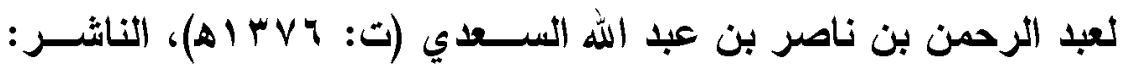

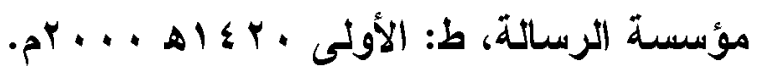
1 ا.تفسير الطبري المسمى: (جامع البيان في تأويل القرآن) لمحمـــ بـن

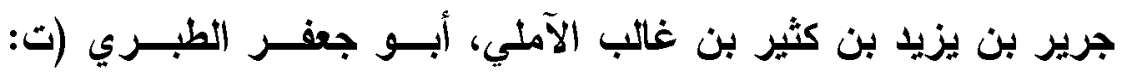

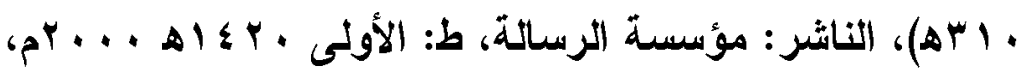
r ا.تفسير القرطبي المسمى: (الجامع لأحكام القرآن) لأبي عبد الله محمـــ

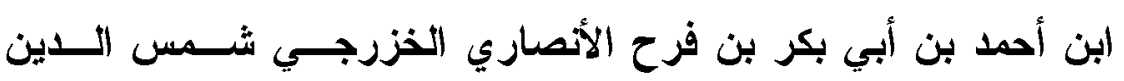

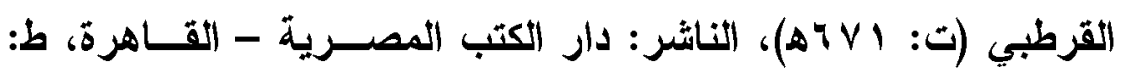
•الثانية ب ا.التفسير الوسيط للاكتور/ وهبة بن مصطفى الزحيلـي، الناشــر: دار

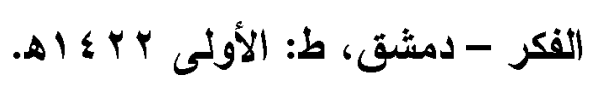

ـ أجامع بيان العلم وفضله لابن عبد البر بن عاصم القرطبي أبـو عمــر يوسف بن عبد الله بن محمد بن عبد البر بن عاصم النمري الثرطبـي

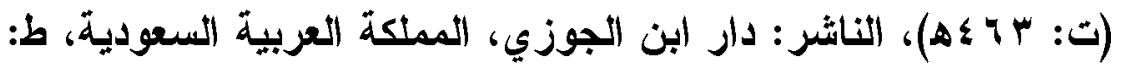

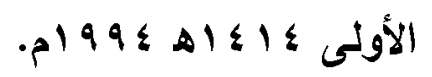

ه اسنن ابن ماجه لأبي عبد الله محمد بن بزيد القزويغي، وماجة اسم أبيه

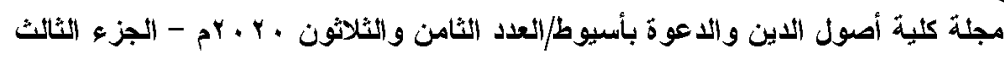




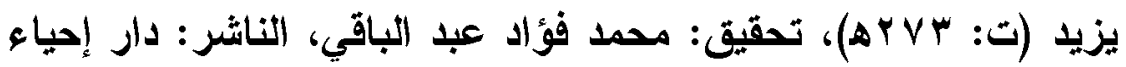
الكتب العربية - فيصل عيسى البابي الحلبي.

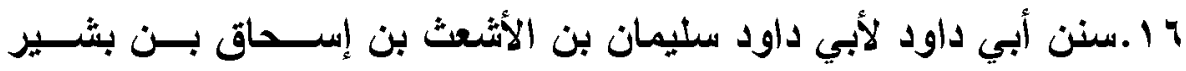
ابن شداد بن عمرو الأزدي الستّبنتاني (ت: • ه هـ)، المحقق: محمد محيب الاين عبد الحميل، التاتشر: المكتبة العصرية، صيدا - بيروت.

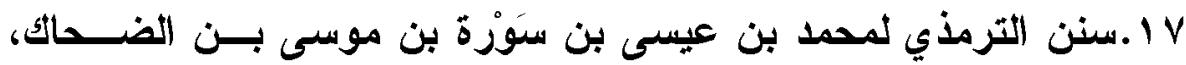

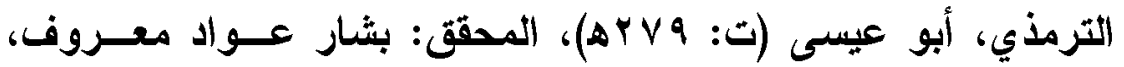

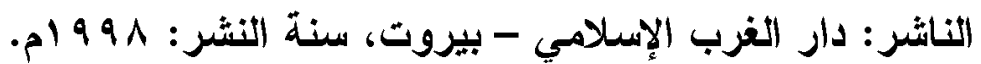

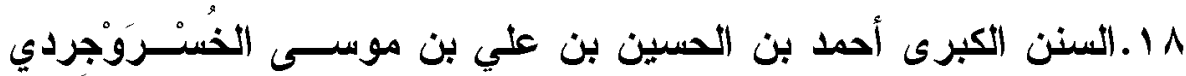

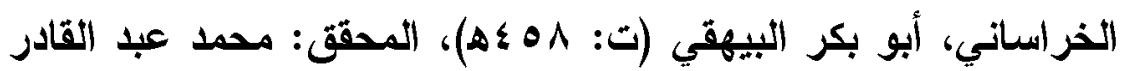
عطا، الناشر: دار الكتب العلمبة، بيروت - لبنان، ط: الثالثة ع ؟ \& اهـ

$$
\cdot p^{r} \cdot r
$$

9 1.صحيح البخاري، المسمى (الجامع المسند الصحيح المختصر من أمور

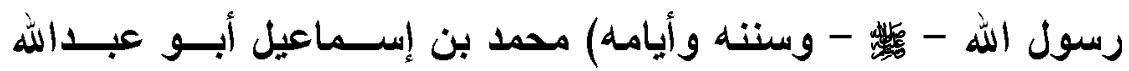
البخاري الجعفي (ت: جه بهـ)، المحقق: محمد زهير بن ناصر الناصر، الناشر : دار طوق النجاة (مصورة عن السلطانية بإضافة ترقيم محمــد فؤاد عبد الباقي)، ط: الأولى r r \& أهـ • ץ.العبودية لتقي الاين أبو العباس أحمد بن عبد الحليم بن عبـــ الســلام

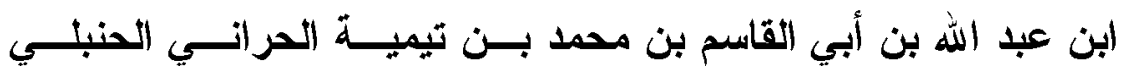

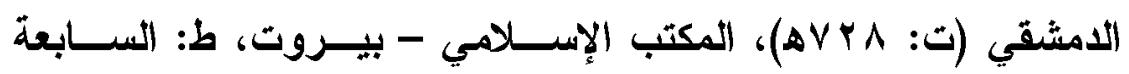

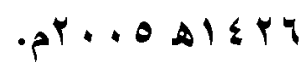




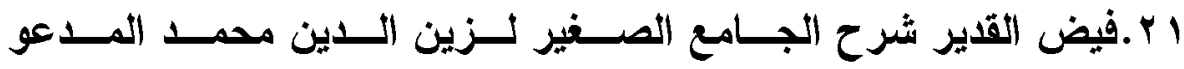
بعبد الرؤوف بن تاج العارفين بن علي بن زين العابدين الحدادي ثُّــ

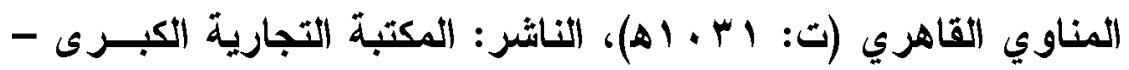

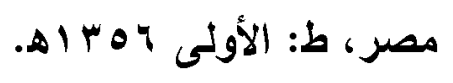

Y Y. القاموس المحيط لمجد الاين أبو طاهر محمد بن يعقوب الفيروزآبادى

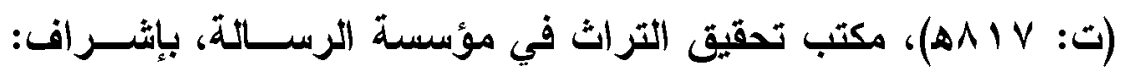

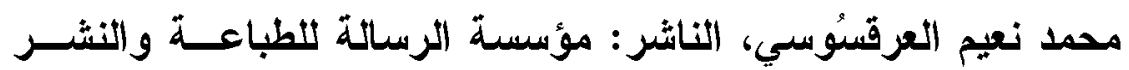

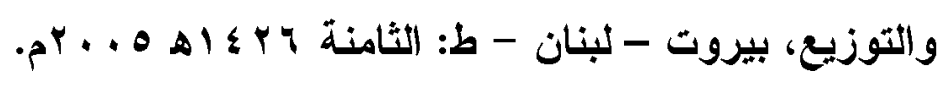

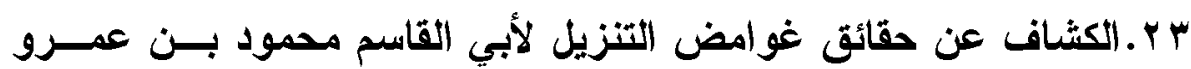

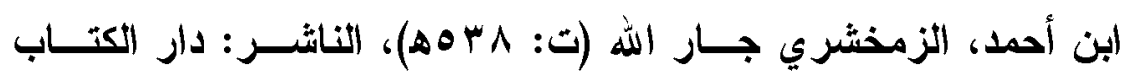

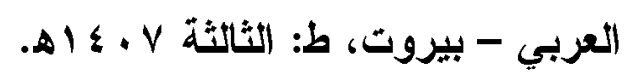

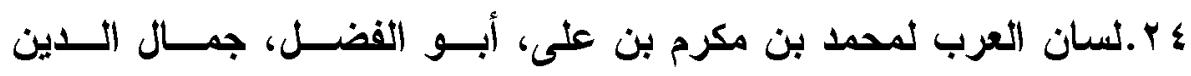

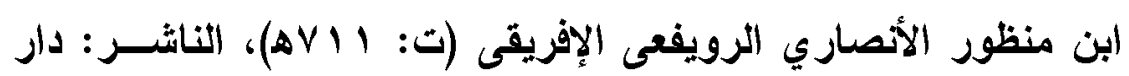

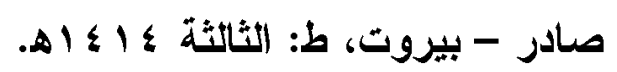

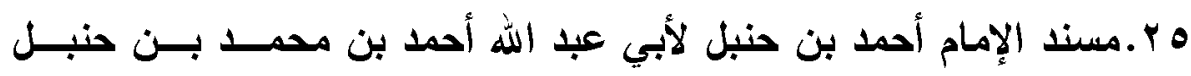

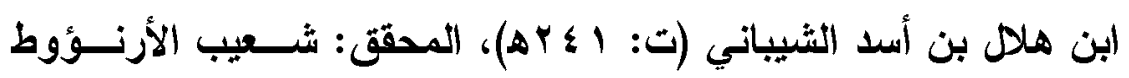

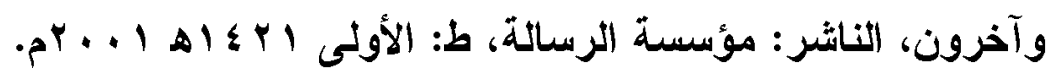

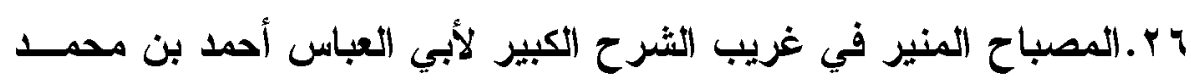

$$
\text { الفيومي ثم الحموي، المكتبة العلمية - بيزوت. }
$$

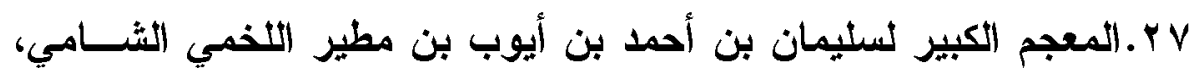

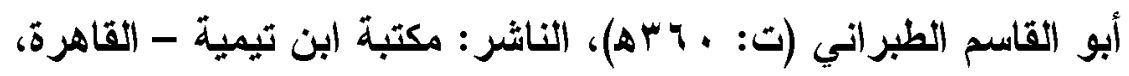

ط: الثانية.

\section{$11 V \varepsilon$}

مجلة كلية أصول الدين و الاعوة بأسبوط/العدد الثامن والثلاثون ·r ·بم - الجزء الثالث 
^ץ..معجم مقاييس اللغة لأحمد بن فارس بن زكرياء القزوينــي الــرازي،

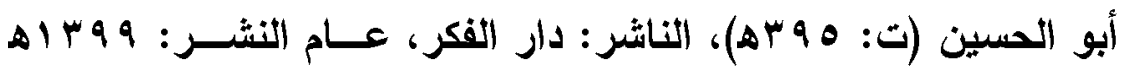
.) $9 \vee 9$

9 ب.معرفة السنن والآثار لأحمد بـن الحسـين بـن علـي بـن موسـى

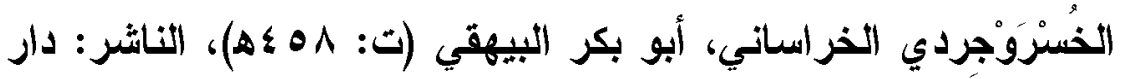

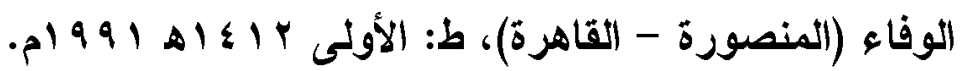

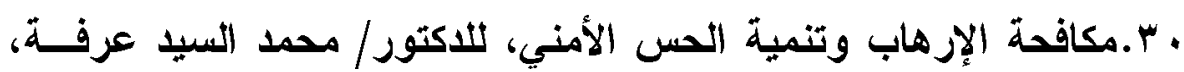
بحث منشور بمجلة البحوث الأمنية - مجلة دورية علمية محكمـة -

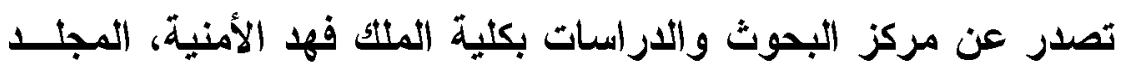

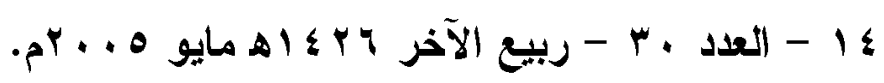

اس.المنهاج شرح صحيح مسلم بن الحجاج لأبي زكريا محيب الاين يحيى

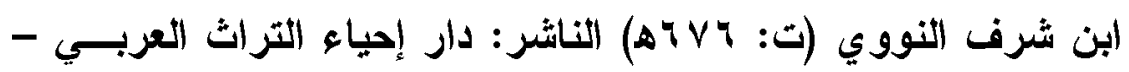

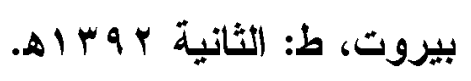

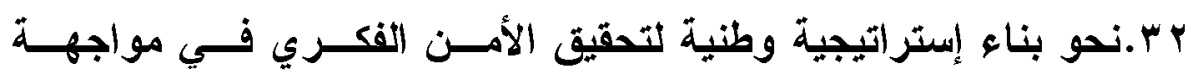

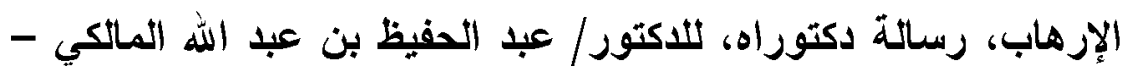

$$
\text { جامعة نايف العربية للعوم الأمنية. }
$$

ب r.وحي القلم لمصطفى صادق الرافعي، الناثر : دار الكتب العلميــة، ط:

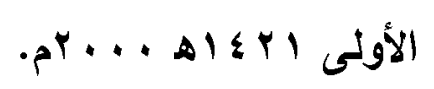

ع ". وسائل القرآن الكريم في تحقيق الأمن الفكري، للاكتورة/ هانم محمـــ عبده عوض بحث منثور بمجلة مجلة البحوث الإســلامية - مجلـة

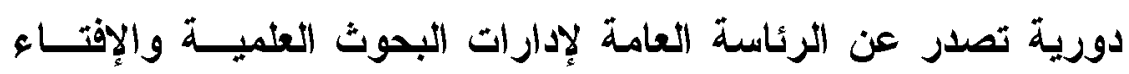


والاعوة والإرشاد، الجزع \& 9 - الصادر في رجب سنة ب بـ اهـ. هـ موسطية الإسدلام وسماحته للاكتور / وهبة بن مصطفى الزحيلي، الكتاب منثور على موقع وزارة الأوقاف السعودية بدون بيانات.

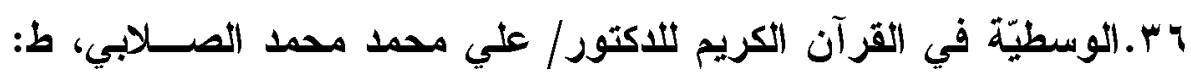
الأولى r Y \& اهـ - مكتبة الصحابة - الإمارات - الثمارقة. 